\title{
Evaluating design criteria for high hazard dams in a changing climate
}

Aaron Read Sutton

West Virginia University, ars0073@mix.wvu.edu

Follow this and additional works at: https://researchrepository.wvu.edu/etd

Part of the Environmental Engineering Commons

\section{Recommended Citation}

Sutton, Aaron Read, "Evaluating design criteria for high hazard dams in a changing climate" (2019). Graduate Theses, Dissertations, and Problem Reports. 3838.

https://researchrepository.wvu.edu/etd/3838

This Thesis is protected by copyright and/or related rights. It has been brought to you by the The Research Repository @ WVU with permission from the rights-holder(s). You are free to use this Thesis in any way that is permitted by the copyright and related rights legislation that applies to your use. For other uses you must obtain permission from the rights-holder(s) directly, unless additional rights are indicated by a Creative Commons license in the record and/ or on the work itself. This Thesis has been accepted for inclusion in WVU Graduate Theses, Dissertations, and Problem Reports collection by an authorized administrator of The Research Repository @ WVU. For more information, please contact researchrepository@mail.wvu.edu. 


\title{
Evaluating design criteria for high hazard dams in a changing climate
}

\author{
Aaron R. Sutton \\ Thesis submitted \\ to the Benjamin M. Statler College of Engineering and Mineral Resources \\ at West Virginia University \\ in partial fulfillment of the requirements for the degree of \\ Master of Science in \\ Civil and Environmental Engineering \\ Leslie Hopkinson, Ph.D., Chair \\ Antarpreet Singh Jutla, Ph.D. \\ John Quaranta, Ph.D. \\ Department of Civil and Environmental Engineering
}

Morgantown, West Virginia

2019

Keywords: 100-year flow, climate change, dam spillways, flow frequency analysis, reservoir routing, Central Appalachia

Copyright 2019 Aaron R. Sutton 


\title{
ABSTRACT \\ Evaluating design criteria for high hazard dams in a changing climate
}

\begin{abstract}
Aaron R. Sutton
With changes in climate, there is the potential for future flooding events to vary in frequency and magnitude. These changes may stress the 432 high hazard dames in West Virginia. The 100year flowrate is an important design criterion for emergency spillways of high hazard dams. Emergency spillways are designed to be reached only by 100 -year flow and above. This work quantified how changes in the 100-year flowrate may affect emergency spillway activation. Peakflow data from the Central Appalachian Ecoregion in WV, taken from 24 USGS gages, were used to analyze changes in the 100 -year flowrate.

Flow frequency analysis revealed that for unregulated gages, 100-year flow consistently increased, but for regulated gages, 100-year flow consistently decreased. Reservoir routing was completed at a high hazard dam in Greenbrier County under potential future flow scenarios altering peak inflow $(-7 \%,+6 \%,+12 \%,+20 \%$, and $+30 \%)$. The spillway of the dam was predicted to be reached by approximately a $12 \%$ increase in 100 -year flow, which was matched and exceeded by historical increases in 100-year flow from unregulated gages of up to $19 \%$. These results suggest that emergency spillway designs need to consider potential changes in 100year flow.
\end{abstract}




\section{ACKNOWLEDGEMENTS}

This research was supported by the NASA West Virginia Space Grant Consortium (WVSGC) Graduate Research Fellowship. The contents of this project are solely the responsibility of the author and do not necessarily represent the official views of others. I would like to thank the NASA WVSGC for selecting me and this research for the fellowship.

I would like to thank the U.S. Army Corps of Engineers for their work on HEC-SSP and the recently updated bulletin $17 \mathrm{C}$ which was useful for this research. Also, I would like to thank the U.S. Geological Survey for their water data collection and distribution.

I would like to thank Dr. Antarpreet Singh Jutla and Dr. John Quaranta for being on my committee and providing their help throughout my graduate education. I am especially grateful to my advisor and committee chair, Dr. Leslie Hopkinson, for her continued assistance and guidance during my entire graduate education.

I would also like to thank my family for their support and reassurance during my time in graduate school. 


\section{Table of Contents}

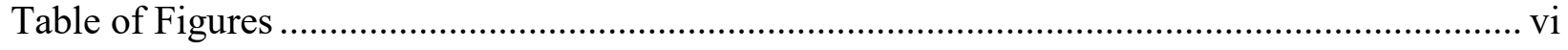

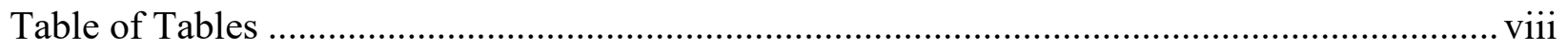

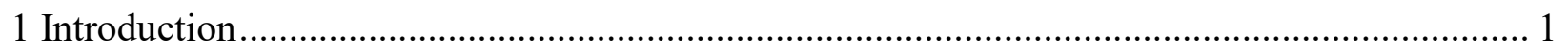

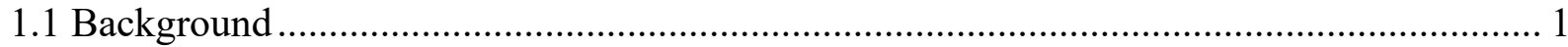

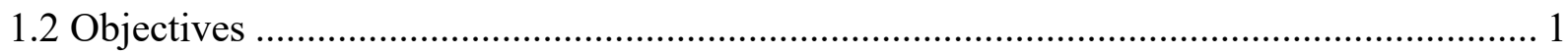

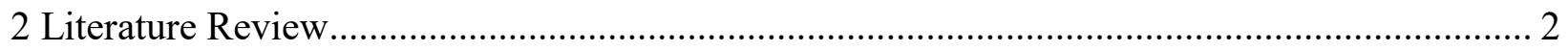

2.1 Hydrological design criteria for dam design................................................................... 2

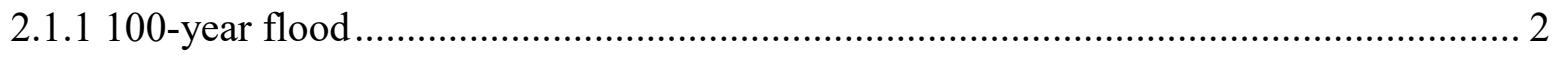

2.1.2 Probable maximum precipitation and probable maximum flood ................................. 2

2.1.3 Dam regulations ............................................................................................. 2

2.2 Extreme events and flooding in Central Appalachia ...................................................... 3

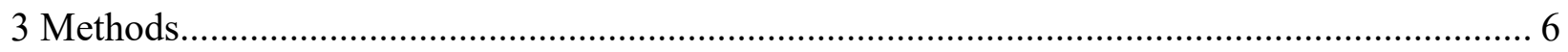

3.1100 -year flow frequency analysis ............................................................................... 6

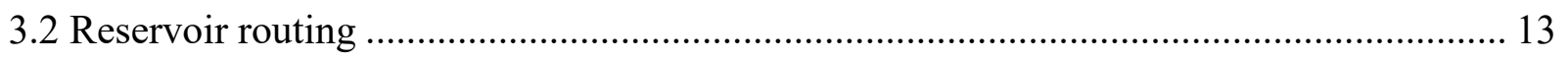

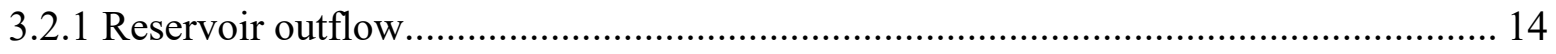

3.2.2 Reservoir storage …………………………..................................................... 17

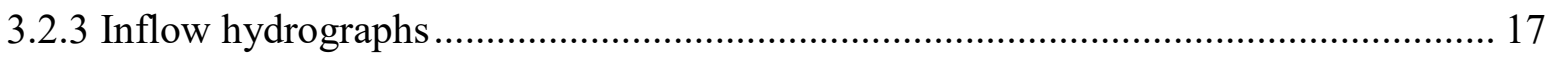

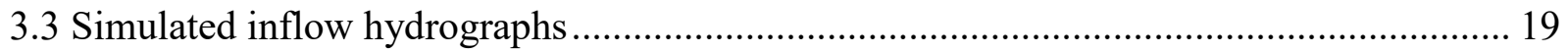

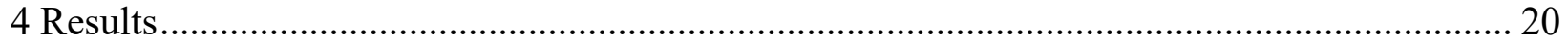

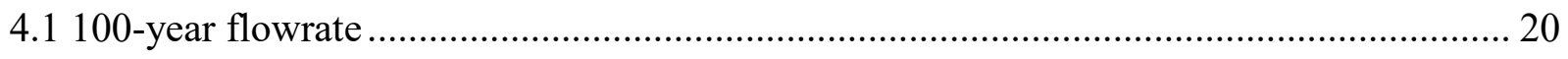

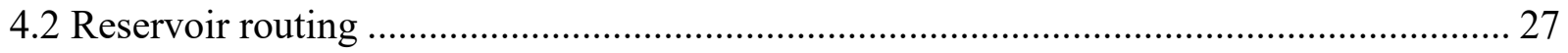

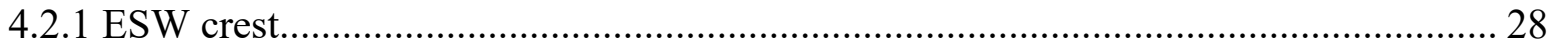

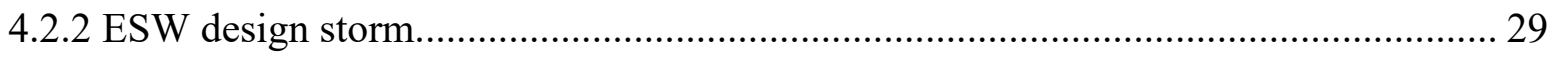

4.2.3 Dam overtopping ................................................................................................. 30

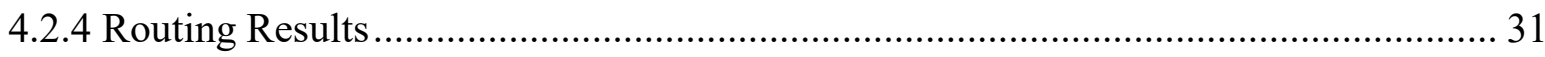

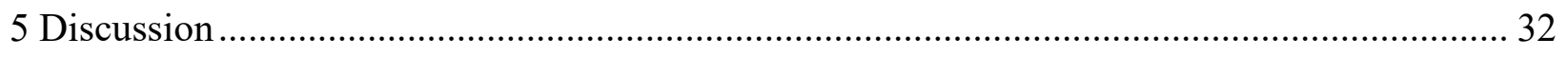

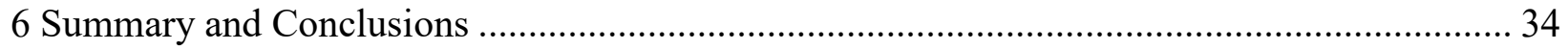

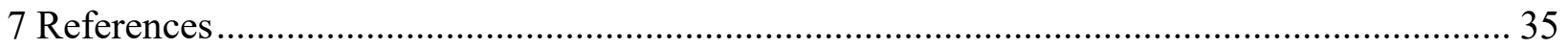

Appendix A - Relative frequency histograms ....................................................................... 38

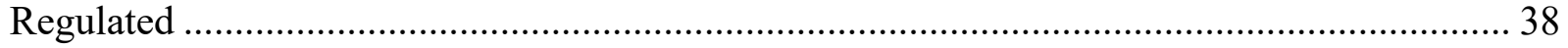




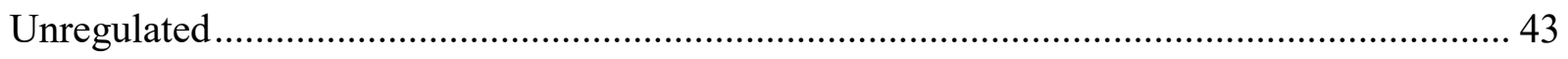

Appendix B: 100-year flow data from HEC-SSP results.................................................... 46 


\section{Table of Figures}

Figure 1: Map of selected USGS gages with streams and relevant dams................................. 7

Figure 2: Map of gages with years of record indicated by size of symbology ........................... 9

Figure 3: Example relative frequency histogram for Greenbrier River at Hilldale gage.............. 11

Figure 4: Periods of record used in each HEC-SSP analysis (1 to 4) with 1 using all available years of record and the method of comparison (percent change) for an example gage (Guyandotte

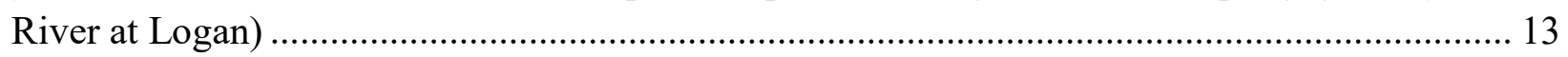

Figure 5: Important elevations of Howard Creek Dam ......................................................... 14

Figure 6: Outflow of the dam vs. elevation using equations 1 through 4 .................................. 16

Figure 7: Crest of ESW inflow hydrograph with peak of $5618 \mathrm{cfs}$ at $3.8 \mathrm{hrs}, \Delta \mathrm{t}=0.2 \mathrm{hr} \ldots \ldots \ldots \ldots 18$

Figure 8: ESW design storm inflow hydrograph with peak of $20387 \mathrm{cfs}$ at $3.8 \mathrm{hrs}, \Delta \mathrm{t}=0.2 \mathrm{hr} \ldots 18$

Figure 9: Dam overtopping inflow hydrograph with peak of $67923 \mathrm{cfs}$ at $3.7 \mathrm{hrs}, \Delta \mathrm{t}=0.1 \mathrm{hr} \ldots . .19$ Figure 10: Average percent change in 100-year flow for regulated gages from (1) analysis using all years of record, to (2) analysis with given starting year, with standard deviation error bars .. 20 Figure 11: 100-year flow for each analysis on Kanawha River at Kanawha Falls gage with large decreases marked with gray ovals............................................................................... 21

Figure 12: Average percent change in 100-year flow for unregulated gages from (1) analysis using all years of record, to (2) analysis with given starting year, with standard deviation error

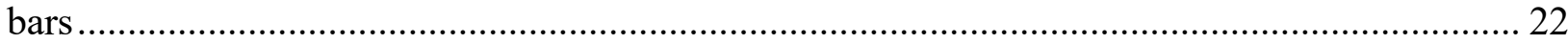

Figure 13: 100-year flow for each analysis on Greenbrier River at Alderson gage ................... 22 Figure 14: Average percent change in 100-year flow for gages in the Greenbrier watershed from (1) analysis using all years of record, to (2) analysis with given starting year, with standard deviation error bars 23

Figure 15: 100-year flow for all years of record by drainage area for regulated and unregulated gages

Figure 16: 100-year flow for all years of record by drainage area for regulated and unregulated gages with two large drainage areas removed 24

Figure 17: Mean confidence interval magnitude of 100-year flow by years of record for all regulated and unregulated gages with standard deviation error bars. 25

Figure 18: Map of regulated and unregulated gage stations with magnitude of 100-year flow indicated by size of symbology. 26 Figure 19: Map of regulated and unregulated gage stations with percent change in 100-year flow from all-year analysis to 30-year analysis indicated by color and size of symbology 27 Figure 20: Peak outflow and peak elevation for crest of ESW scenarios with oval indicating where peak outflow reaches crest of ESW ....................................................................... 29 Figure 21: Peak outflow and peak elevation for ESW design storm scenarios ........................ 30 Figure 22: Peak outflow and peak elevation for dam overtopping scenarios with oval indicating where peak outflow reaches dam crest ............................................................................... 30 Figure 23: Relative frequency histogram for Big Sandy Creek at Rockville gage..................... 38 Figure 24: Relative frequency histogram for Tygart Valley River at Belington gage................. 38 
Figure 25: Relative frequency histogram for Sand Run near Buckhannon gage....................... 38

Figure 26: Relative frequency histogram for Little Kanawha River near Wildcat gage ............. 39

Figure 27: Relative frequency histogram for Bluestone River near Pipestem gage ................... 39

Figure 28: Relative frequency histogram for New River at Thurmond gage ............................ 39

Figure 29: Relative frequency histogram for Gauley River near Craigsville gage..................... 40

Figure 30: Relative frequency histogram for Gauley River above Belva gage .......................... 40

Figure 31: Relative frequency histogram for Kanawha River at Kanawha Falls gage............... 40

Figure 32: Relative frequency histogram for Elk River below Webster Springs gage................ 41

Figure 33: Relative frequency histogram for Elk River at Queen Shoals gage ........................ 41

Figure 34: Relative frequency histogram for Guyandotte River near Baileysville gage ............. 41

Figure 35: Relative frequency histogram for Guyandotte River at Logan gage ........................ 42

Figure 36: Relative frequency histogram for East Fork Twelvepole Creek nr Dunlow gage ...... 42

Figure 37: Relative frequency histogram for Tug Fork downstream of Elkhorn Creek at Welch

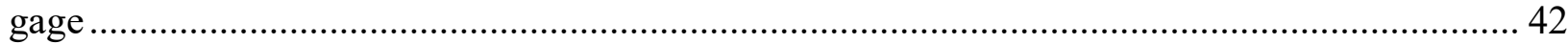

Figure 38: Relative frequency histogram for Tug Fork at Kermit gage ................................. 43

Figure 39: Relative frequency histogram for Blackwater River at Davis gage ......................... 43

Figure 40: Relative frequency histogram for Greenbrier River at Buckeye gage ...................... 43

Figure 41: Relative frequency histogram for Greenbrier River at Alderson gage.................... 44

Figure 42: Relative frequency histogram for Greenbrier River at Hilldale gage ...................... 44

Figure 43: Relative frequency histogram for Williams River at Dyer gage ............................ 44

Figure 44: Relative frequency histogram for Cranberry River near Richwood gage ................. 45

Figure 45: Relative frequency histogram for Big Coal River at Ashford gage ........................ 45

Figure 46: Relative frequency histogram for Clear Fork at Clear Fork gage ........................... 45 


\section{Table of Tables}

Table 1: USGS Gages used in larger analysis

Table 2: High hazard $(\mathrm{H})$ and significant hazard $(\mathrm{S})$ dam classification on the streams of the

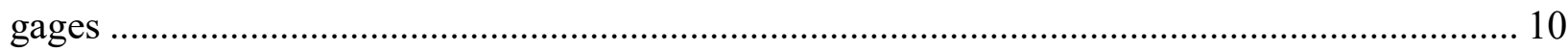

Table 3: USGS gages used in Greenbrier River analysis .................................................. 10

Table 4: Equations used to find discharge as function of elevation ..................................... 16

Table 5: Discharge and storage at specified elevations used for storage-indication curve ......... 17

Table 6: Frequency storms corresponding to percent change scenarios.................................. 28

Table 7: Outcomes of reservoir routing analysis ................................................................ 31

Table 8: All results for all gages from HEC-SSP frequency analyses including gage name, USGS gage number, and total years of record along with 100-year flow, variance, and confidence limits

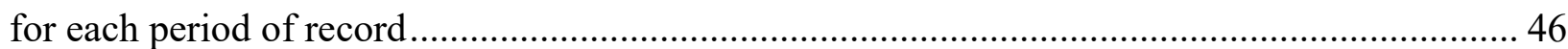




\section{Introduction}

\subsection{Background}

West Virginia (WV) has experienced an increased frequency of major rainstorms and floods partly due to climate change, and further increases are predicted due to past temperature increases in the state of $0.5^{\circ} \mathrm{F}$ to $1^{\circ} \mathrm{F}$ over the last century (USEPA 2016). The increased rainfall results in increased flow through WV streams, putting increased stress on the 432 state high hazard dams (from National Inventory of Dams), dams that can cause loss of life if they fail (USACE 2018b). More than $60 \%$ of the dams in WV were built before 1970 , so many of these dams are nearing the end of their design life of 50 years (NRCS 2016b). To ensure effective functioning of these dams, they will soon require rehabilitation.

Recently, there have been flood-related disaster declarations in WV almost every year (USEPA 2016). The emergency spillway of a high hazard dam is intended to operate only once each 100 years, known as 100-year storm. With the intense rainfall experienced in WV, the 100year storm and 100-year flow have risen, resulting in increased flow toward dams (Milly et al. 2002). Additionally, urban development and other land use changes have increased the area of impervious surfaces in $\mathrm{WV}$, resulting in decreased infiltration and increased runoff into streams (Ferrari et al. 2009). Surface coal mining is one of these significant land use changes, increasing runoff during extreme events (Evans et al. 2015). The increased flow in streams means that flood risks are higher than the past.

\subsection{Objectives}

The objective of this research was to determine if dam design criteria for high hazard dam emergency spillways remain adequate, despite changing climate with increased extreme precipitation events. The first task was to determine how the 100-year flood has changed over time in the Central Appalachian Ecoregion (CAE) within WV. A number of scenarios were generated with the 100-year flow data in WV in the CAE. The second task was to determine how the changes in 100-year flowrate may impact dam design criteria for an existing dam. Specifically, Howard Creek Dam, an earth/rockfill dam in Greenbrier County, was examined to find how changes in the 100-year flood may impact flow in the emergency spillway. The dam is in a rural watershed with few changes in land use over the study period, so climate changes were the focus of research. 


\section{Literature Review}

\subsection{Hydrological design criteria for dam design}

\subsubsection{0-year flood}

A 100-year flood is a flood that has a $1 \%$ annual exceedance probability (Holmes 2017). The measurement of streamflow data over at least 30 years gives the average over that time period, and the 100-year flood is calculated from these data. The 100-year portion is known as the average recurrence interval of such a flood, so there would be a 1-in-100 chance that a flood with equal or greater discharge would occur in any given year. The 100-year flood is a crucial consideration for dam design because it is used to design emergency spillways in high hazard dams (WVDEP 2009). The reservoir pool elevation that a 100 -year flood is projected to reach is the elevation at which the crest of an emergency spillway of a high hazard dam is placed. Urban development and dams can have a strong impact on the occurrence of floods, so flow data before a large-scale human change can become obsolete after development changes are made (USGS 2018).

\subsubsection{Probable maximum precipitation and probable maximum flood}

Another important metric for designing a dam is the probable maximum precipitation (PMP). PMP is the most precipitation that could feasibly occur in a specific time period in a specific location and time of year without considering long-term changes in climate (Tetzlaff and Zimmer 2013). Some high-hazard dams need to be designed to handle these PMP storms to prevent catastrophic failure and minimize extreme flooding events. From PMP and local watershed qualities such as soil moisture and upstream regulation, the probable maximum flood (PMF) can be calculated. PMF is the largest flood that could feasibly occur in a specific area and is often considered in dam design (LaRocque 2013).

\subsubsection{Dam regulations}

High hazard dams are the dams which have the largest consequences of failure. Hazard designation is based on the failure of a dam during worst case scenarios, such as floodflow conditions. The risk of dam failure is calculated from probability of failure and consequence of failure (FEMA 2014). Notably, it is possible for hazard designation of a dam to change due to 
downstream development. In West Virginia, more than $60 \%$ of the dams were built prior to 1970. West Virginia has 285 high hazard dams as of 2017. Now, these dams are nearly at the end of their design life of 50 years, and they may require rehabilitation (NRCS 2016b). If the frequency and intensity of storms are increasing, current spillway designs may not be sufficient for flood management.

The following are the hazard classifications for dams in West Virginia (WVDEP 2009):

1. Class 1: For class 1 (high hazard) dams, failure may cause loss of human life, or major damage to infrastructure. These are designed to the 6-hour PMP and no less than 70\% PMP. Their spillways should operate no more than once in 100 years for a 6-hour rainfall event.

2. Class 2: For class 2 (significant hazard) dams, failure may cause minor damage to infrastructure, but loss of human life is unlikely. These are designed to $50 \%$ of the 6hour PMP, and no less than 25\% PMP. Their spillways should operate no more than once in 50 years for a 6-hour rainfall event.

3. Class 3: For class 3 (low hazard) dams, failure would cause little damage to adjacent property. The main loss would be to the dam itself. These are designed to $25 \%$ of the 6 hour PMP, and no less than the 6-hour 100-year storm. Their spillways should operate no more than once in 25 years for a 6-hour rainfall event.

4. Class 4: For class 4 (negligible hazard) dams, failure causes almost no harm. Class 4 dams are often associated with other, larger dams. These are designed to the 6-hour 100year storm. As with class 3 dams, their spillways should operate no more than once in 25 years for a 6-hour rainfall event. For dams of any hazard designation that are designed to overtop, they should be designed not to overtop more than once in 100 years for a 6-hour rainfall event (WVDEP 2009).

Notably, the Federal Emergency Management Agency has since merged class 3 and class 4 dams, resulting in only three classifications at the national level, but WV has not updated its dam safety rule since 2009 (FEMA 2014).

\subsection{Extreme events and flooding in Central Appalachia}

In the Northeastern U.S., rising trends have been found for extreme precipitation and streamflow events. In the 2000 s, the frequency of extreme precipitation events was higher than 
any previous decade on record. However, the 1970s and 2000s had similar peaks in the frequency of extreme streamflow events. The most significant trends are observed when looking only at the changes between the warm seasons of each year. From 1980 to the 2000s, the frequency of warm season extreme precipitation events increased $30-40 \%$, and the frequency of warm season extreme streamflow events doubled (Frei et al. 2015).

The number of "2-day, 1-in-5-year storms" from 2001 to 2012 is nearly double the average from 1901-2012, indicating a strong increase in extreme precipitation events in the 2000s (Walsh et al. 2014). The intensity of extreme precipitation events is increasing as well. In the heaviest $1 \%$ of daily rainfall events from 1958 to 2012 in the Northeast which contains WV, the amount of precipitation has increased by $71 \%$ (Walsh et al. 2014).

In a study by Milly et al. (2002), climate change, defined by a projected quadrupling of atmospheric $\mathrm{CO}_{2}$, is predicted to increase the risk of 100-year floods in several large ( $>200,000$ $\mathrm{km}^{2}$ ) river basins around the world. One of these basins is the Ohio River Basin which encompasses most of West Virginia. This basin is predicted to have a $2.3 \%$ chance each year of what is currently only a $1 \%$ AEP flood.

One study predicts that climate change will increase the frequency of extreme precipitation events in the Northeast, and the average yearly flood damages in the Northeast are expected to rise by $\$ 750$ million by 2100 as a result. The southern Appalachians and Ohio River Valley are expected to experience 2 to 5 times more 100-year floods by 2100. The model accounts for the projected changes in frequency and adjusts the 100-year flood over time (Wobus et al. 2017).

Another study uses General Circulation Models (GCMs) for large-scale climate modeling and prediction (temperature and precipitation) and scales them down with statistical methods. These GCMs were used to identify climate extremes in the northeastern U.S. under different emissions scenarios from 2050-2099, comparing them to results from 1950-1999. As emissions increased, the number of warm days in the region increased dramatically. In WV (Ohio River Valley), the following results were found for the change in the number of extreme warm days per year ("number of days with maximum temperature higher than $90^{\text {th }}$ percentile of daily maximum temperature") across three emissions scenarios:

- Low emissions: 30-40 more warm days

- Moderate emissions: 50-70 more warm days 
- High emissions: $80+$ more warm days.

Because of the increase in number of extreme warm days, an increase in precipitation intensity is also projected in the Ohio River Valley. Across the northeastern U.S., the variability from year to year of extreme climate events is predicted to increase, making preparation for these events much more difficult (Ning et al. 2015).

In the Appalachian Region, surface coal mining has impacted the hydrology of those areas through changes in topography, soil structure, and vegetation. The peakflows during extreme precipitation events at mined or recently reclaimed watersheds have increased (Evans et al. 2015). The mechanisms for these mining influences are similar to the hydrological impacts of urbanizing an area, resulting in low infiltration and high runoff (Ferrari et al. 2009). However, there is a lack of understanding of the effects of mining on discharge during different intensities of precipitation events because it is likely that the varying intensities activate different flow paths (Murphy et al. 2014). Messinger (2003) recorded the per-unit-area peakflows from two adjacent sites in West Virginia, one mined and one unmined, and found that high intensity storms with rainfall greater than $2.5 \mathrm{~cm} / \mathrm{hr}$ had higher peakflows at the mined site as found above. However, storms of lower intensity had higher peakflows at the unmined site. These differences are likely due to soil saturation differences between the two sites. 


\section{Methods}

For the first task, 100-year flow frequency analysis was completed for 24 USGS gages using HEC-SSP (USACE 2018a). Eighteen scenarios were generated for peakflow change over time. For the second task, reservoir routing was used to find the water surface elevations reached at Howard Creek Dam under the scenarios from the first task.

\subsection{0-year flow frequency analysis}

For this task, peak annual flowrate data were compiled from 24 existing United States Geological Survey (USGS) stream monitoring stations (USGS 2018). From these flowrate data, the 100-year flood was calculated for these existing gage stations. The criteria for selecting these stations was as follows: 1) station reports peak annual flowrate; 2) station has a long period of record (at least 30 years) without gaps; and 3) station is located in WV and the Central Appalachian Ecoregion. The selections were accomplished using Excel and ArcMap. Then ArcMap was used to determine whether each selected gage was located in a regulated or unregulated channel (Figure 1). A regulated channel was defined as a channel with a dam anywhere on the length of the channel; an unregulated channel was defined as a channel without any dams. Ecoregions are expected to be relatively uniform in climate. The Central Appalachian Ecoregion is known for its mountains and environmental diversity, and the ecoregion was chosen because of its associations with surface coal mining and high variations in annual precipitation from year to year (USEPA 2018). 


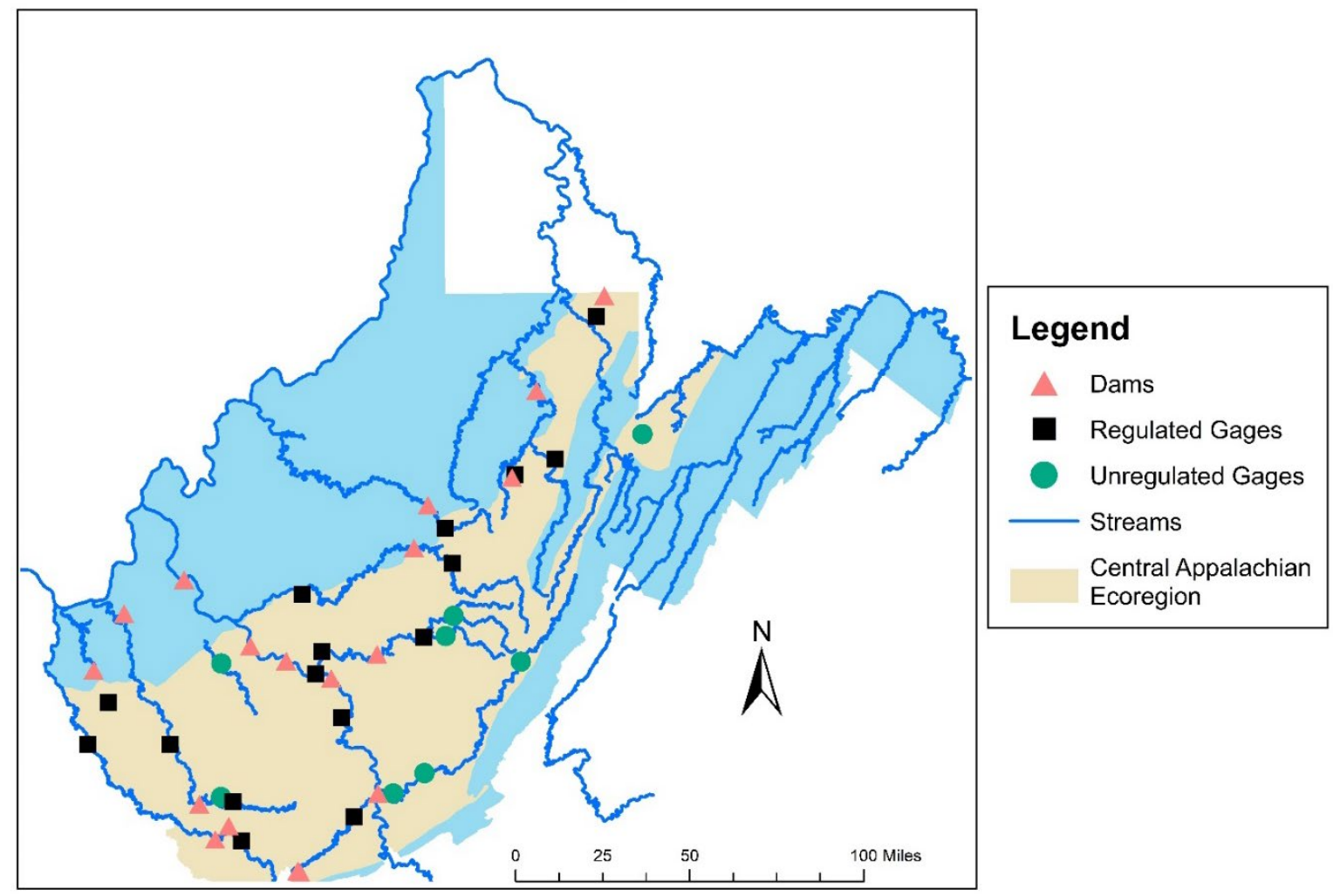

Figure 1: Map of selected USGS gages with streams and relevant dams

This selection process resulted in a total of 24 gages with varying periods of record. All periods of record extend to the present (Table 1) (Figure 2). Sixteen of these gages were regulated due to dams on the stream (Table 2), and eight were unregulated. The drainage areas of the gages ranged from approximately 14 to $8,371 \mathrm{mi}^{2}$. One gage station, Greenbrier River at Durbin, was added only to a second analysis (Table 3) which used the four unregulated gages in the Greenbrier watershed because Howard Creek Dam is located in the Greenbrier watershed. 
Table 1: USGS Gages used in larger analysis

\begin{tabular}{|c|c|c|c|c|c|c|}
\hline $\begin{array}{c}\text { USGS } \\
\text { Site } \\
\text { Number } \\
\end{array}$ & Station Name & Abbrev. & $\begin{array}{c}\text { Years } \\
\text { of } \\
\text { record }\end{array}$ & $\begin{array}{c}\text { Year } \\
\text { range }\end{array}$ & $\begin{array}{r}\text { Drainage } \\
\text { area }\left(\mathbf{m i}^{2}\right)\end{array}$ & Regulated \\
\hline 03066000 & Blackwater River at Davis & BRD & 96 & $1922-2017$ & 85.9 & $\mathrm{~N}$ \\
\hline 03182500 & Greenbrier River at Buckeye & GRB & 88 & $1930-2017$ & 540 & $\mathrm{~N}$ \\
\hline 03183500 & Greenbrier River at Alderson & GRA & 122 & $1896-2017$ & 1364 & $\mathrm{~N}$ \\
\hline 03184000 & Greenbrier River at Hilldale & GRH & 82 & $1936-2017$ & 1619 & $\mathrm{~N}$ \\
\hline 03186500 & Williams River at Dyer & WRD & 89 & $1930-2017$ & 128 & $\mathrm{~N}$ \\
\hline 03187500 & Cranberry River Near Richwood & CRR & 34 & 1984-2017 & 80.4 & $\mathrm{~N}$ \\
\hline 03198500 & Big Coal River at Ashford & $\mathrm{BCA}$ & 87 & $1931-2017$ & 391 & $\mathrm{~N}$ \\
\hline 03202750 & Clear Fork at Clear Fork & $\mathrm{CFC}$ & 43 & $1975-2017$ & 126 & $\mathrm{~N}$ \\
\hline 03051000 & Tygart Valley River at Belington & TVR & 110 & $1908-2017$ & 406 & $\mathrm{Y}$ \\
\hline 03052500 & Sand Run Near Buckhannon & SRB & 71 & $1947-2017$ & 14.3 & $\mathrm{Y}$ \\
\hline 03070500 & Big Sandy Creek at Rockville & BSC & 96 & $1922-2017$ & 200 & $\mathrm{Y}$ \\
\hline 03151400 & Little Kanawha River nr Wildcat & LKR & 32 & $1986-2017$ & 112 & $\mathrm{Y}$ \\
\hline 03179000 & Bluestone River Near Pipestem & BRP & 67 & $1951-2017$ & 395 & $\mathrm{Y}$ \\
\hline 03185400 & New River at Thurmond & NRT & 37 & $1981-2017$ & 6687 & $\mathrm{Y}$ \\
\hline 03189100 & Gauley River Near Craigsville & GRC & 32 & $1986-2017$ & 529 & $\mathrm{Y}$ \\
\hline 03192000 & Gauley River Above Belva & GRV & 89 & 1929-2017 & 1317 & $\mathrm{Y}$ \\
\hline 03193000 & Kanawha River at Kanawha Falls & KRK & 140 & $1878-2017$ & 8371 & $\mathrm{Y}$ \\
\hline 03194700 & Elk River Below Webster Springs & ERW & 32 & $1986-2017$ & 266 & $\mathrm{Y}$ \\
\hline 03197000 & Elk River at Queen Shoals & ERQ & 89 & $1929-2017$ & 1145 & $\mathrm{Y}$ \\
\hline 03202400 & $\begin{array}{l}\text { Guyandotte River near } \\
\text { Baileysville }\end{array}$ & GRN & 49 & $1969-2017$ & 306 & $\mathrm{Y}$ \\
\hline 03203600 & Guyandotte River at Logan & GRL & 57 & $1961-2017$ & 833 & $\mathrm{Y}$ \\
\hline 03206600 & $\begin{array}{l}\text { East Fork Twelvepole Creek } \\
\text { Near Dunlow }\end{array}$ & EFT & 53 & $1965-2017$ & 37.9 & $\mathrm{Y}$ \\
\hline 03212750 & $\begin{array}{l}\text { Tug Fork downstrm of Elkhorn } \\
\text { Creek at Welch }\end{array}$ & TFE & 32 & $1986-2017$ & 174 & $\mathrm{Y}$ \\
\hline 03214500 & Tug Fork at Kermit & TFK & 88 & 1930-2017 & 1280 & $\mathrm{Y}$ \\
\hline
\end{tabular}

Note: $\mathrm{Y}=\mathrm{Yes}, \mathrm{N}=\mathrm{No}$ 


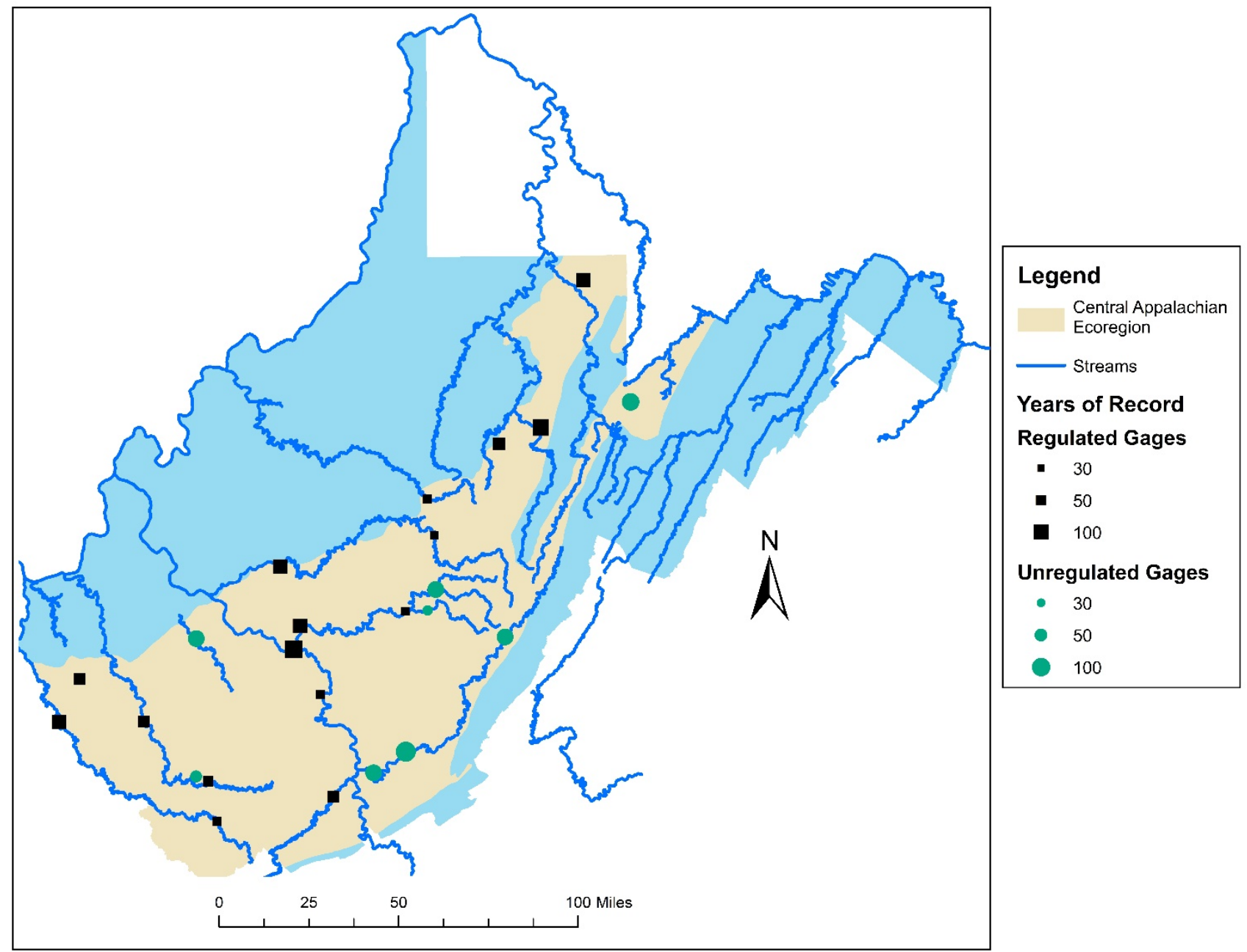

Figure 2: Map of gages with years of record indicated by size of symbology 


\section{Table 2: High hazard (H) and significant hazard (S) dam classification on the streams of the gages}

\begin{tabular}{llcc}
\hline Dam Name & River & $\begin{array}{c}\text { Year } \\
\text { completed }\end{array}$ & Hazard \\
\hline Camp Roy Weler Lake & Big Sandy Ck & 1965 & $\mathrm{~S}$ \\
Jimmy Lewis Dam & Bluestone River & 1965 & $\mathrm{H}$ \\
New Bramwell Dam & Bluestone Rv & 1970 & $\mathrm{H}$ \\
Old Bramwell Dam & Bluestone Rv & 1929 & $\mathrm{H}$ \\
East Lynn Dam & East Fk Twelvepole Creek & 1971 & $\mathrm{H}$ \\
Sutton Dam & Elk River & 1960 & $\mathrm{H}$ \\
Summersville Dam & Gauley River & 1965 & $\mathrm{H}$ \\
Hatfield Farm Lake & Guyandotte River & 1955 & $\mathrm{H}$ \\
R D Bailey Dam & Guyandotte River & 1976 & $\mathrm{H}$ \\
London L \& D & Kanawha River & 1934 & $\mathrm{~S}$ \\
Marmet L \& D & Kanawha River & 1934 & $\mathrm{~S}$ \\
Winfield L \& D & Kanawha River & 1937 & $\mathrm{~S}$ \\
Burnsville Lake Dam & Little Kanawha River & 1976 & $\mathrm{H}$ \\
Bluestone Dam & New River & 1947 & $\mathrm{H}$ \\
Hawks Nest & New River & 1936 & $\mathrm{H}$ \\
Hall's Farm Pond & Sand Run & 1959 & $\mathrm{H}$ \\
Twin Branch Dam No.1 & Tug Fork & 1920 & $\mathrm{H}$ \\
Wilmore Dam & Tug Fork & 1950 & $\mathrm{~S}$ \\
Tygart Dam & Tygart River & 1938 & $\mathrm{H}$ \\
\hline
\end{tabular}

Note: $\mathrm{S}=$ Significant, $\mathrm{H}=$ High

Table 3: USGS gages used in Greenbrier River analysis

\begin{tabular}{clccccc}
\hline $\begin{array}{c}\text { USGS } \\
\text { Site } \\
\text { Number }\end{array}$ & Station Name & Abbrev. & $\begin{array}{c}\text { Years } \\
\text { of } \\
\text { record }\end{array}$ & $\begin{array}{c}\text { Year } \\
\text { range }\end{array}$ & $\begin{array}{c}\text { Drainage } \\
\text { area (mi }\end{array}$ & Regulated \\
\hline 03180500 & Greenbrier River at Durbin & GRD & 74 & $1944-2017$ & 133 & $\mathrm{~N}$ \\
03182500 & Greenbrier River at Buckeye & GRB & 88 & $1930-2017$ & 540 & $\mathrm{~N}$ \\
03183500 & Greenbrier River at Alderson & GRA & 122 & $1896-2017$ & 1364 & $\mathrm{~N}$ \\
03184000 & Greenbrier River at Hilldale & GRH & 82 & $1936-2017$ & 1619 & $\mathrm{~N}$ \\
\hline
\end{tabular}

Note: $\mathrm{N}=\mathrm{No}$

After selecting the gages, relative frequency histograms were graphed from the raw peakflow data to determine the general behavior of the data for each gage with an example graphed below 
(Figure 3). To determine the number of class intervals for each histogram, the following formula was used:

$$
k=5 \log _{10} n
$$

with $k$ equal to the number of class intervals and $n$ equal to the number of data values (Bedient et al. 2013). Complete data are available in Appendix A.

The histogram of each gage is expected to be positively skewed, and all gages have apparent positive skew with the exceptions of the New River at Thurmond and Big Coal River at Ashford gages. The New River at Thurmond gage had peakflow values that were marked as "affected by regulation or diversion" on nearly every year of data (USGS 2018). The Big Coal River at Ashford gage appears to have peakflows with a bimodal distribution which could be due to the proximity of the gage to the Kanawha River, which has many dams, or due to changes in the Big Coal River watershed.

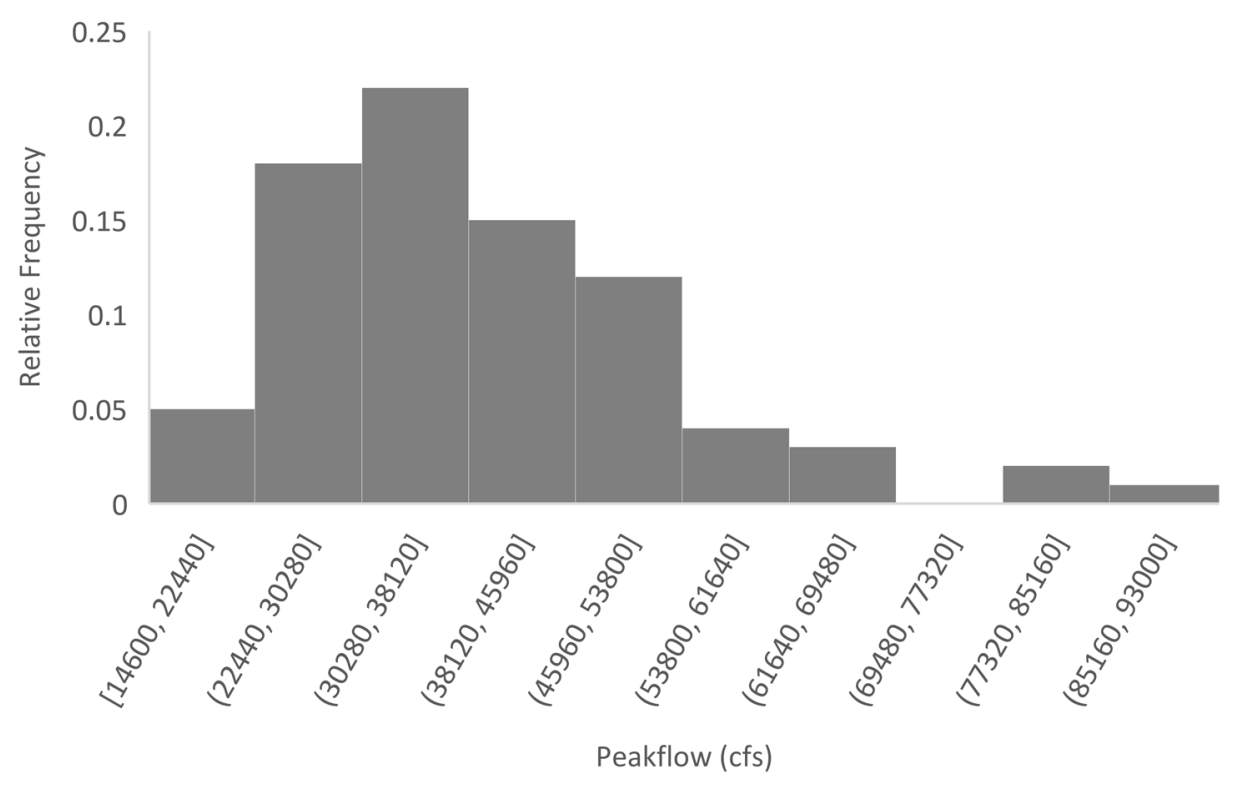

Figure 3: Example relative frequency histogram for Greenbrier River at Hilldale gage

Frequency analysis was completed for all selected stream gages to determine the 100year flowrate for each stream over its entire period of record. In addition, the 100-year flowrates for each of the following periods of record were calculated: the most recent 20 years of data, the most recent 30 years of data, the most recent 40 years of data, the most recent 50 years of data, 
the most recent 60 years of data, the most recent 70 years of data, and the most recent 80 years of data.

Hydrologic Engineering Center Statistical Software Package (HEC-SSP), developed by the Army Corps of Engineers, was used to perform these analyses using the flow frequency analysis option which fits the peakflow data from a gage to the log Pearson type III distribution with the Expected Moments Algorithm (EMA) to determine the flow frequency curve (USACE 2018a). Log Pearson type III distribution was used because this distribution is bounded on the left, positively skewed, transformed by logarithms, and implemented in HEC-SSP, allowing the flow magnitudes to be easily computed for a 100-year return period (Bedient et al. 2013). The distribution does generally match the peakflow data from the gages with positive skew. From the results of this analysis, the 1\% AEP (100-year flow) was determined. When analyses with different periods of record were compared, they yielded the change in frequency of extreme events over time. For each gage, percent change between analyses of different periods of record was calculated because it gives each gage equal weight in the analysis (Figure 4). The equation used is as follows:

$$
P_{C}=\frac{Q_{n e w}-Q_{o l d}}{Q_{o l d}} \times 100
$$

with $P_{C}=$ percent change, $Q_{n e w}=$ new flowrate, and $Q_{o l d}=$ old flowrate. 


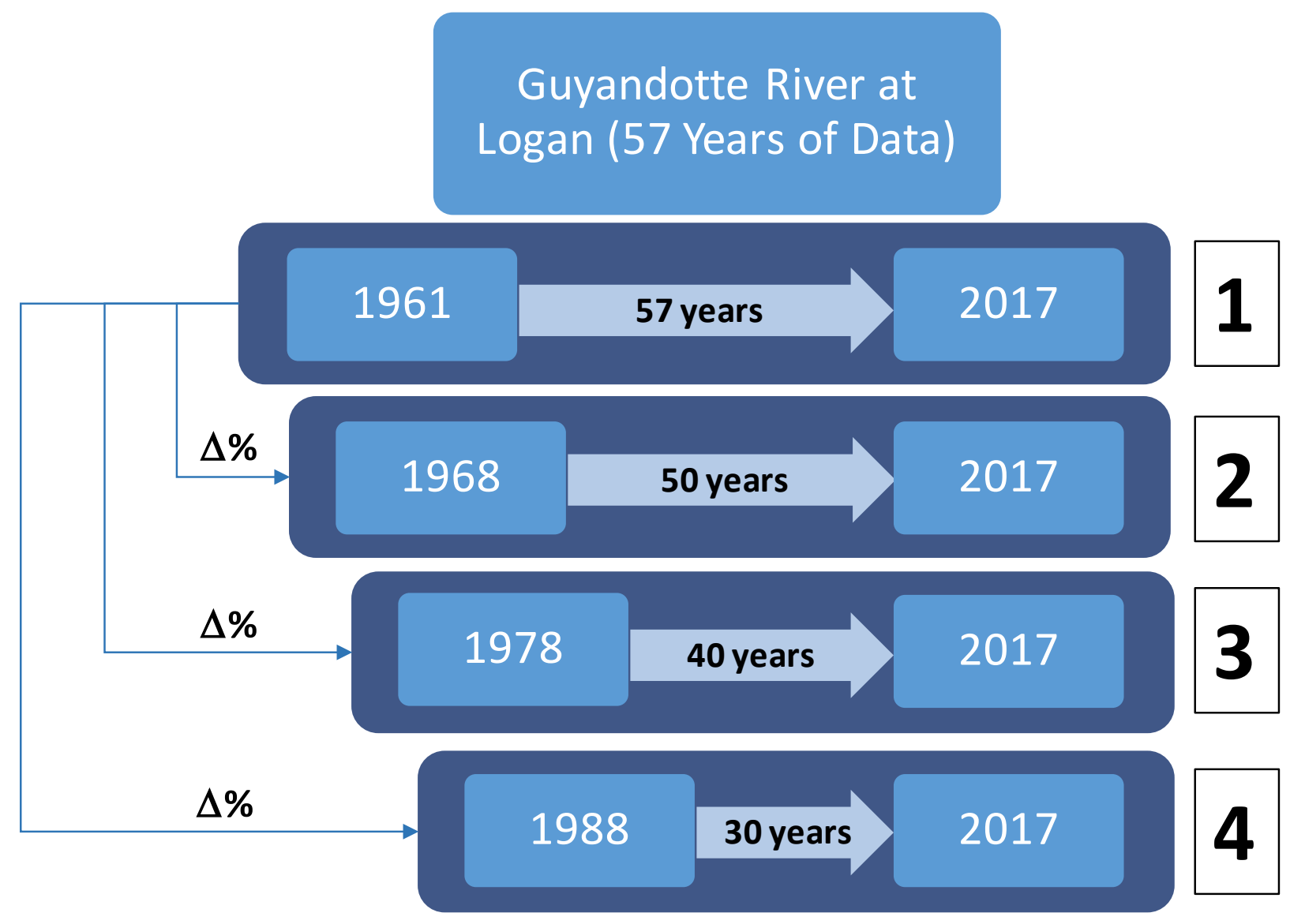

Figure 4: Periods of record used in each HEC-SSP analysis (1 to 4) with 1 using all available years of record and the method of comparison (percent change) for an example gage (Guyandotte River at Logan)

\subsection{Reservoir routing}

For the second task, changes in 100-year flow design values were evaluated at Howard Creek Dam in White Sulphur Springs, WV. Howard Creek Dam is located in Dry Creek in Greenbrier County upstream of White Sulphur Springs. The reservoir of the dam is Lake Tuckahoe. The Dry Creek watershed has a drainage area of $13.5 \mathrm{mi}^{2}$. The land use in the area near the dam is mostly dominated by 9000 acres of forest with around 640 acres of farmland and pastures as well (NRCS 1992b). From the previous analysis, 20 scenarios were developed and the simulated flows were routed through the dam using the storage-indication method (Bedient et al. 2013). The elevations were then compared to elevations of Howard Creek Dam spillways and 
dam crest (Figure 5) to determine whether the water surface reached these points in the scenarios. The dam elevations and properties were acquired from the design report (NRCS 1992a)

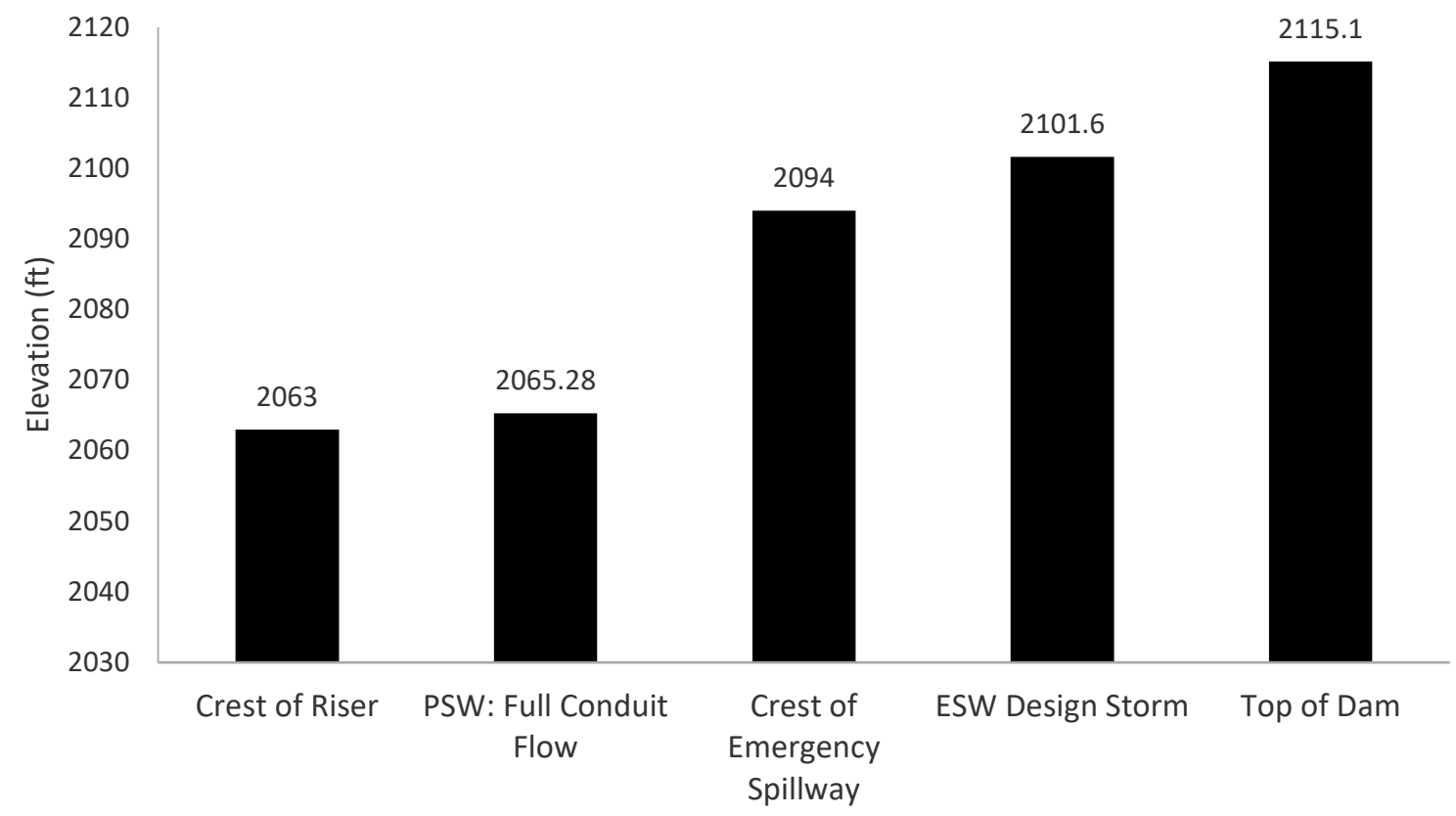

Figure 5: Important elevations of Howard Creek Dam

\subsubsection{Reservoir outflow}

Outflows were composed of three outlet structures: principal spillway, emergency spillway, and dam crest. The relationships used to model outflow are described in the following paragraphs. The normal principal spillway flow was modeled as a sharp-crested weir and calculated by the following equation (Bedient et al. 2013):

$$
Q_{\text {weir }}=C_{e} \frac{2}{3} B \sqrt{2 g}\left(h-h_{0}\right)^{1.5}
$$

where $\mathrm{Q}$ is spillway discharge; $\mathrm{C}_{\mathrm{e}}$ is a weir discharge coefficient; $\mathrm{g}$ is acceleration due to gravity; $\mathrm{B}$ is the length of the spillway perpendicular to flow; $h$ is the input elevation; and $\mathrm{h}_{0}$ is the 
elevation of the crest of the spillway. The emergency spillway flow and dam overflow were modeled as broad-crested weirs and calculated by the following equation (Bedient et al. 2013):

$$
Q_{\text {weir }}=C_{e} \frac{2}{3} L \sqrt{2 g}\left(h-h_{0}\right)^{1.5}
$$

where $\mathrm{Q}$ is spillway discharge; $\mathrm{C}_{\mathrm{e}}$ is a weir discharge coefficient; $\mathrm{g}$ is acceleration due to gravity; $\mathrm{L}$ is the length of the spillway parallel to flow; $\mathrm{h}$ is the input elevation; and $\mathrm{h}_{0}$ is the elevation of the crest of the spillway. Discharge coefficients and other features were informed by the hydrology report of the dam (NRCS 1992b).

The flow through the dam was broken down into equations (Table 4) describing different stages of flow (Figure 6). The $\mathrm{C}_{\mathrm{e}}=0.58$ for equation 4 was taken from the dam hydrology report and applied to equations 6 and 7 as well due to lack of weir discharge coefficient data on these sections (NRCS 1992b). The lengths of the spillways parallel to flow were $\mathrm{L}=19.33 \mathrm{ft}, \mathrm{L}=190 \mathrm{ft}$, and $\mathrm{L}=451.3 \mathrm{ft}$ for normal principal spillway flow, emergency spillway flow, and dam crest flow respectively. The dam crest length was acquired from an average of four ArcMap measurements of the full length of the dam at different points along the dam. The following are descriptions of the equations used for flow through the dam:

- From the elevation of the crest of the riser (2063 ft) to the elevation of full conduit flow (2065.28 ft), a weir equation was used for normal principal spillway flow (NRCS 1992b) resulting in equation 4 in Table 4.

- From the elevation of full conduit flow through the principal spillway (2065.28 ft) to the elevation of the crest of the emergency spillway (2094 ft), a quadratic equation fit to the rating table in the hydrology report (NRCS 1992b) was used for full conduit flow through the principal spillway resulting in equation 5 in Table 4.

- From the elevation of the crest of the emergency spillway (2094 ft) to the elevation of the dam crest $(2115.1 \mathrm{ft})$, the full conduit flow through the principal spillway and a weir equation for emergency spillway flow were added together resulting in equation 6 in Table 4. 
- Above the dam crest $(2115.1 \mathrm{ft})$, full conduit flow through the principal spillway and flow through the emergency spillway and a weir equation for flow over the dam crest were added together resulting in equation 7 in Table 4.

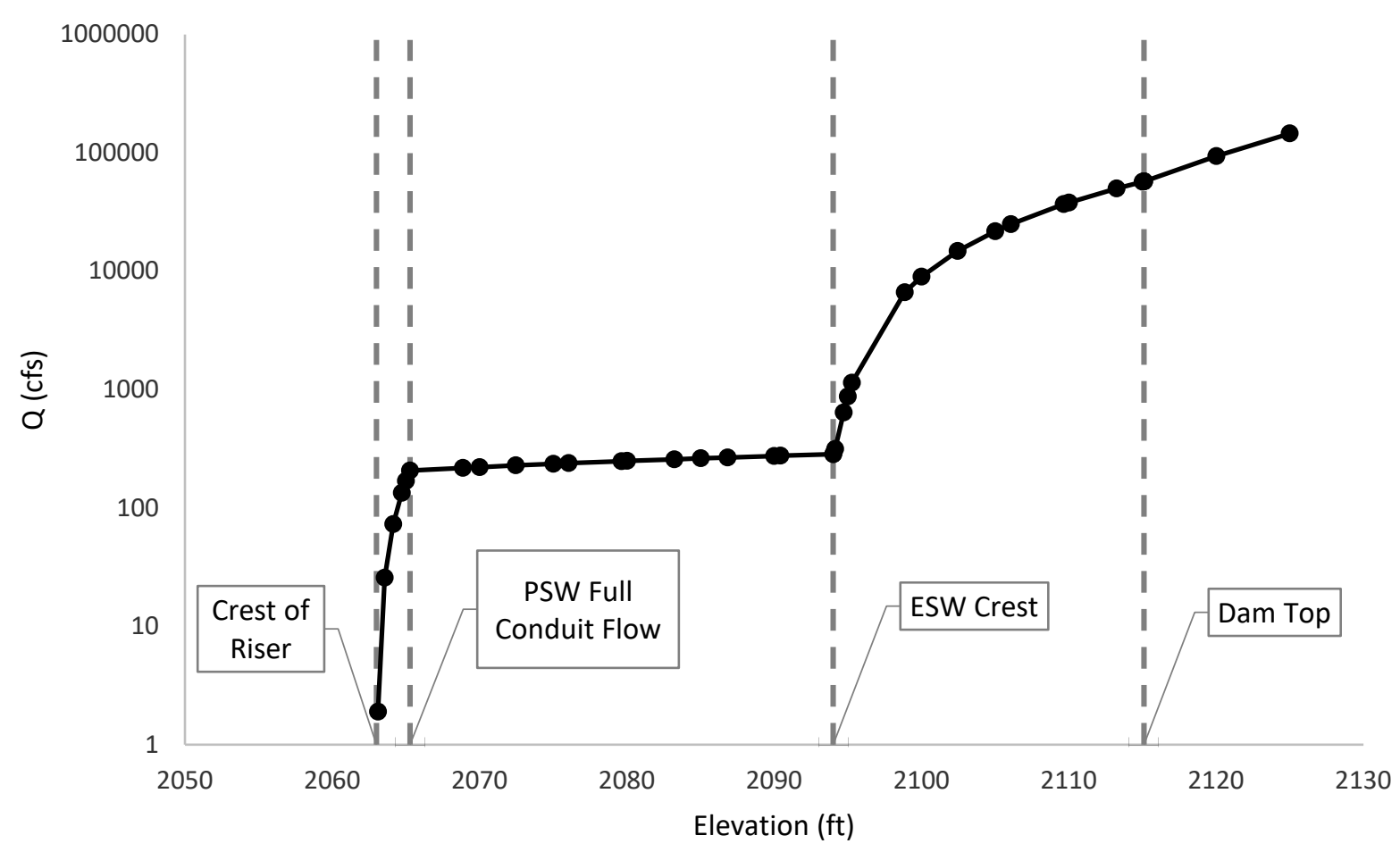

Figure 6: Outflow of the dam vs. elevation using equations 1 through 4

Table 4: Equations used to find discharge as function of elevation

\begin{tabular}{|l|l|l|l|}
\hline Stage & Elevation $(\mathbf{f t})$ & Flowrate Equation $(\mathbf{c f s})$ & \\
\hline Crest of Riser & $2063-2065.28$ & $Q=59.92(h-2063)^{1.5}$ & $(5)$ \\
\hline $\begin{array}{l}\text { Full Conduit Flow } \\
\text { through PSW }\end{array}$ & $2065.29-2094$ & $Q=-0.014809(h-2063)^{2}+3.1784(h-2063)+199.45$ & $(6)$ \\
\hline Crest of ESW & $2094.01-2115.1$ & $\begin{array}{l}Q=589.6(h-2094)^{1.5}-0.014809(h-2063)^{2}+ \\
3.1784(h-2063)+199.45\end{array}$ & $(7)$ \\
\hline Dam Crest & $>2115.1$ & $\begin{array}{l}Q=1400(h-2115.1)^{1.5}+589.6(h-2094)^{1.5}- \\
0.014809(h-2063)^{2}+3.1784(h-2063)+199.45\end{array}$ & $(8)$ \\
\hline
\end{tabular}




\subsubsection{Reservoir storage}

Storage-indication curves were calculated using the known cumulative volumes of the reservoir at specific elevations and the discharges from the above equations at those given elevations (Table 5) (NRCS 1992b). The curves had discharge on the $y$-axis and $Q+2 S / \Delta t$ in the $\mathrm{x}$-axis with $\mathrm{S}=$ storage $\left(\mathrm{ft}^{3}\right)$ and $\Delta \mathrm{t}=$ time interval (hrs) of the inflow hydrographs. Ponded condition was assumed, meaning that the water surface elevation of the permanent pool was assumed to be the same as the elevation of the crest of the riser.

Table 5: Discharge and storage at specified elevations used for storage-indication curve

\begin{tabular}{cccc}
\hline $\begin{array}{l}\text { Elevation } \\
\text { (ft) }\end{array}$ & $\begin{array}{l}\text { Head (H) } \\
\text { (ft) }\end{array}$ & $\begin{array}{l}\text { Discharge (Q) } \\
\text { (cfs) }\end{array}$ & $\begin{array}{l}\text { Storage (S) } \\
\left.\text { (ft }^{\mathbf{3}}\right)\end{array}$ \\
\hline 2063 & 0 & 0 & 0 \\
2065 & 2 & 169.5 & 3568430 \\
2070 & 7 & 221.0 & 13837685 \\
2075 & 12 & 235.5 & 26115052 \\
2080 & 17 & 249.2 & 40692384 \\
2085 & 22 & 262.2 & 57873730 \\
2090 & 27 & 274.5 & 77339358 \\
2095 & 32 & 997.6 & 98519505 \\
2100 & 37 & 10755.1 & 121377581 \\
2105 & 42 & 26268.0 & 145965857 \\
2110 & 47 & 45858.5 & 172323974 \\
2115 & 52 & 68804.9 & 201069175 \\
\hline
\end{tabular}

\subsubsection{Inflow hydrographs}

Inflow hydrographs were calculated for three conditions: i) ESW crest inflow, ii) ESW design storm inflow, and iii) dam overtop inflow. Peak flowrates and time to peak were determined from the hydrology report (NRCS 1992b). Time of fall was calculated assuming a synthetic triangular hydrograph, using the following equation (Bedient et al. 2013): 


$$
T_{F}=1.67 * T_{R}
$$

where $\mathrm{T}_{\mathrm{F}}=$ time of fall and $\mathrm{T}_{\mathrm{R}}=$ time of rise. The given peak inflow to reach the crest of the emergency spillway was $5618 \mathrm{cfs}$ at 3.8 hours which was the 100-year flow from the design report (Figure 7). The given peak inflow for the ESW design storm was $20387 \mathrm{cfs}$ at 3.8 hours which was calculated from 100-year flow and PMP in the design report (Figure 8). The given peak inflow for reaching the dam crest was 67923 cfs at 3.7 hours which was the PMP from the design report (Figure 9) (NRCS 1992a). The inflow was routed from the reservoir through the dam using the inflow hydrograph and the storage-indication curve iteratively to calculate the outflow through the dam.

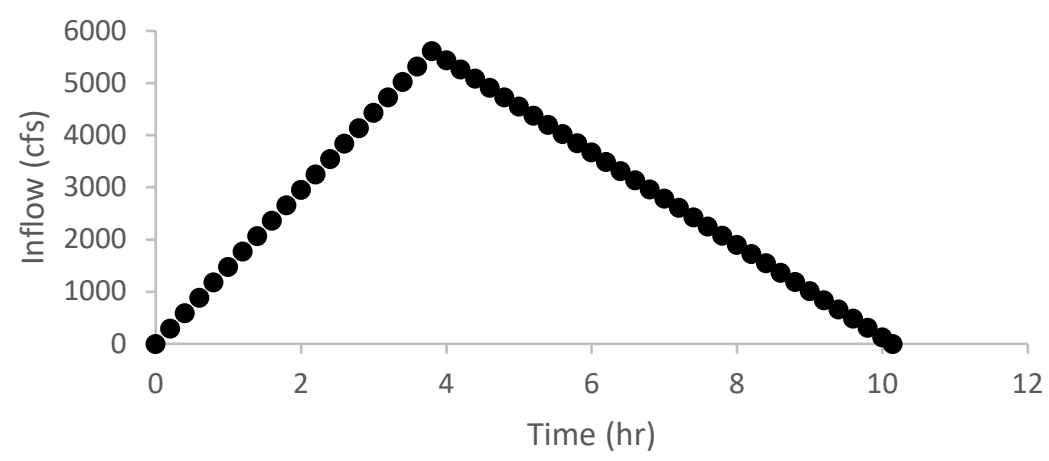

Figure 7: Crest of ESW inflow hydrograph with peak of $5618 \mathrm{cfs}$ at $3.8 \mathrm{hrs}, \Delta \mathrm{t}=0.2 \mathrm{hr}$

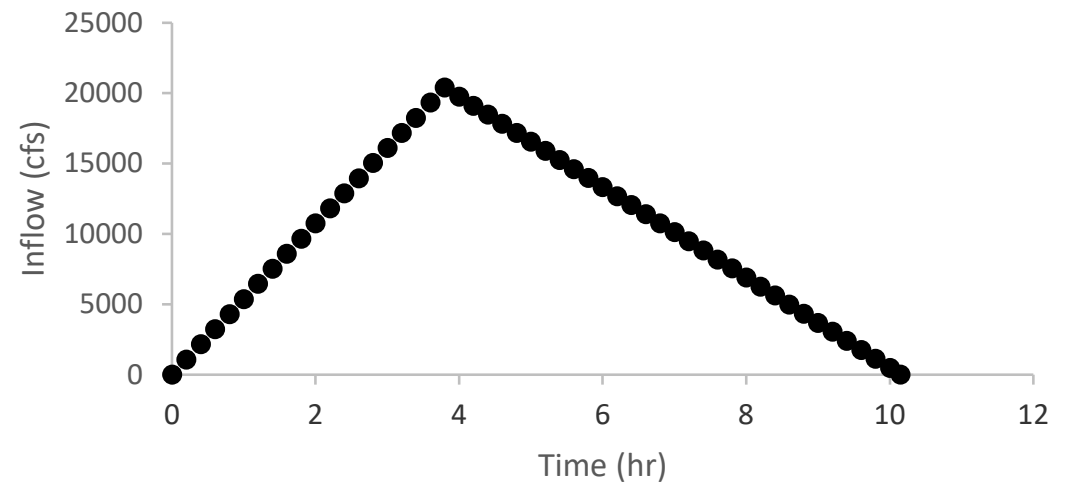

Figure 8: ESW design storm inflow hydrograph with peak of $20387 \mathrm{cfs}$ at $3.8 \mathrm{hrs,} \Delta \mathrm{t}=\mathbf{0 . 2} \mathrm{hr}$ 


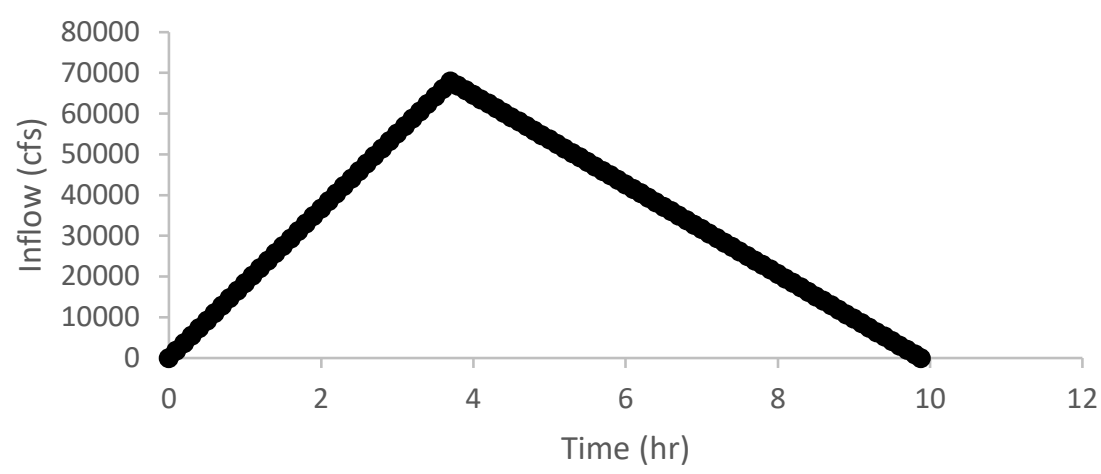

Figure 9: Dam overtopping inflow hydrograph with peak of 67923 cfs at $3.7 \mathrm{hrs}, \Delta \mathrm{t}=\mathbf{0 . 1} \mathrm{hr}$

\subsection{Simulated inflow hydrographs}

Several scenarios were developed that simulated changes in peak inflow over time based on the results of the 100-year flow analysis portion of research. The scenarios included the following changes to peak inflow: $-7 \%,+6 \%,+12 \%,+20 \%,+30 \%$. These changes were applied mainly to the crest of ESW inflow because the scenarios were based on 100-year flow. The justification for each scenario will be explained in the results and discussion section.

After applying the above scenarios to the crest of ESW, the scenarios were applied to ESW design storm and dam overtopping as well. However, the changes were only based on 100-year flow, so the scenarios may not fully explain changes to ESW design storm and dam overtopping since they include PMP. 


\section{Results}

\subsection{0-year flowrate}

The results of the 100-year flood analysis revealed varying patterns for regulated and unregulated gages and depending on period of record. Period of record had a larger effect on 100-year flow for unregulated gages than for regulated gages as shown by the smaller magnitude in percent change for regulated gages (Figures 10 and 11). This makes intuitive sense because the regulated gages are on streams with dams that regulate flow to keep it from changing too drastically over time. In fact, the constant negative percent change in 100-year flow shows that over time 100-year flow for regulated gages has decreased over time despite climate change (Figure 10).

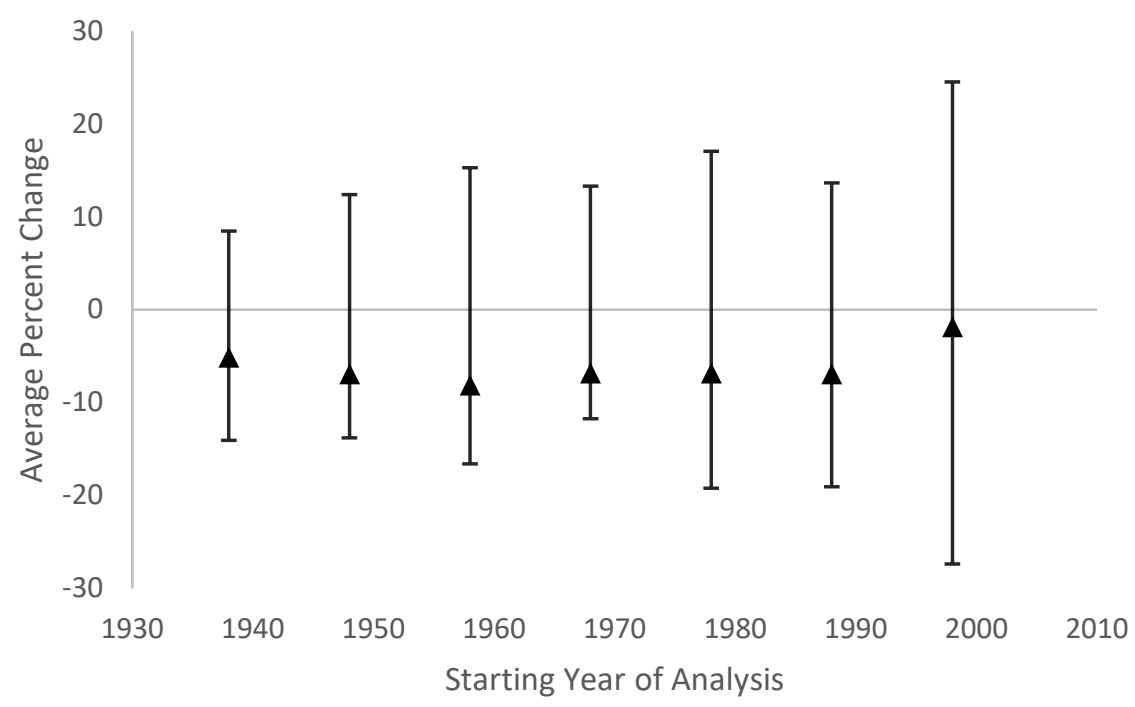

Figure 10: Average percent change in 100-year flow for regulated gages from (1) analysis using all years of record, to (2) analysis with given starting year, with standard deviation error bars

One possible explanation for this effect is the building of dams in the middle of peakflow period of record of the dam, lowering the peakflows for the gages in that stream. An example of this effect is the 100-year flow graph for each analysis on the Kanawha River at Kanawha Falls gage (Figure 11). Dams were built on the Kanawha River in 1901, 1934 (two), and 1937, and these are the years at which there are drastic decreases in 100-year flow. Once these large percent decreases in 100-year flow due to dam construction or simply dam regulation are 
averaged across all the regulated gages, they could cause the average percent change to be negative.

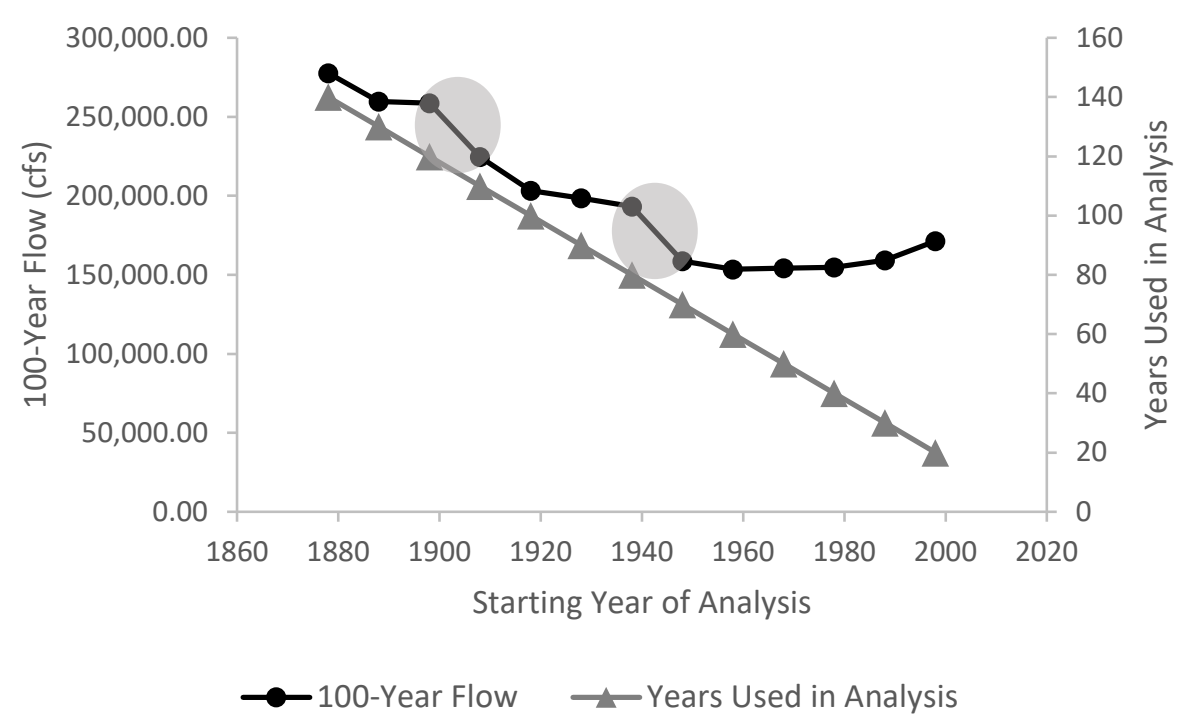

Figure 11: 100-year flow for each analysis on Kanawha River at Kanawha Falls gage with large decreases marked with gray ovals

Though regulated gage 100-year flow has decreased over time, the 100-year flow for unregulated gages has increased as expressed by the consistently positive average percent changes for unregulated gages (Figure 12). Also, the unregulated gages have approximately 47\% lower standard deviation than the regulated gages on average. 


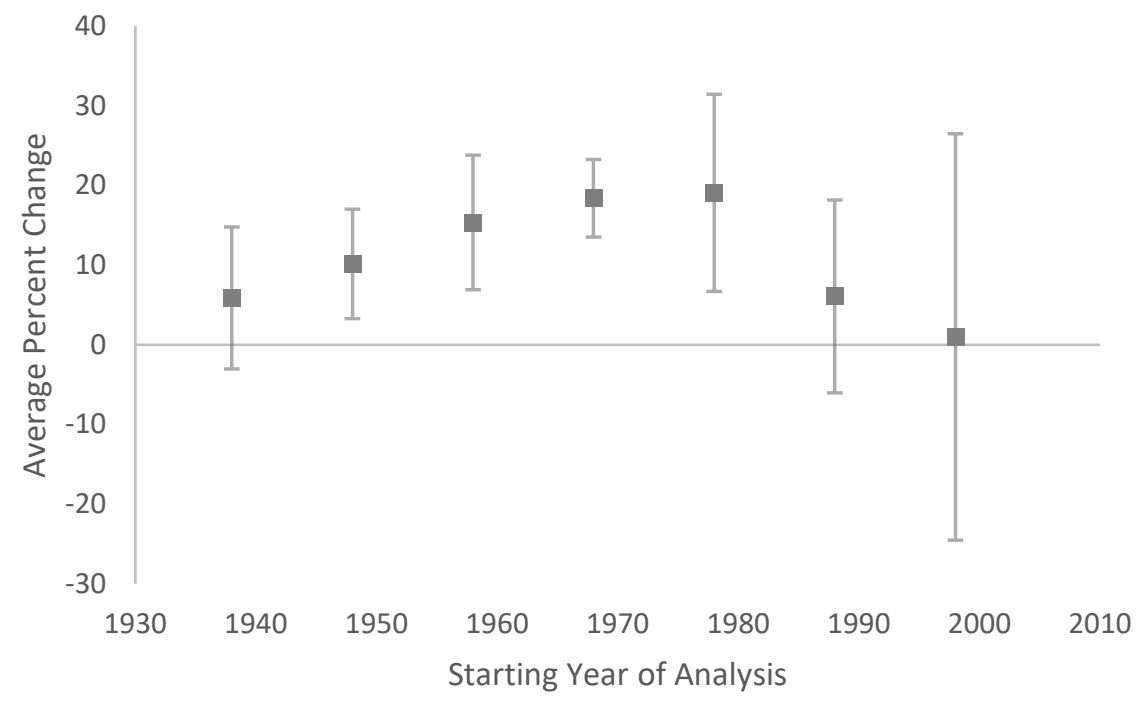

Figure 12: Average percent change in 100-year flow for unregulated gages from (1) analysis using all years of record, to (2) analysis with given starting year, with standard deviation error bars

These increases in 100-year flow are likely explained by climate change, increase in impervious surfaces from urbanization, long term cyclic climate trends, and surface coal mining among other effects (Evans et al. 2015) (Ferrari et al. 2009). As an example, the Greenbrier River at Alderson gage has increased in 100-year flow with each successive analysis until the last couple analyses (Figure 13).

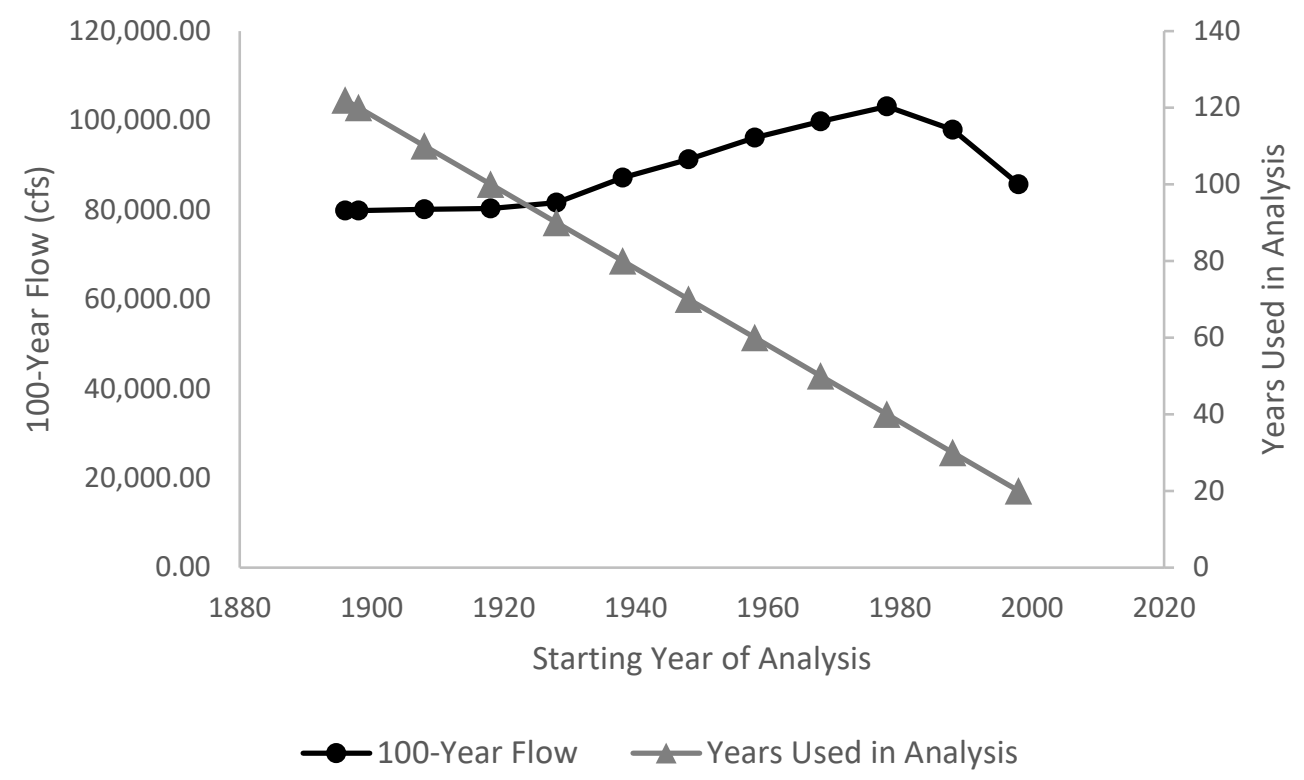

Figure 13: 100-year flow for each analysis on Greenbrier River at Alderson gage 
Because of the location of Howard Creek Dam in the Greenbrier watershed, another analysis focused only on the gages in the Greenbrier watershed (Figure 14). This analysis follows the general shape of the unregulated gage analysis but with fewer periods of record and with a higher peak percent change at approximately $30 \%$. Also, the analysis starting in 1998 drops to negative percent change, but this analysis only includes 20 years of data.

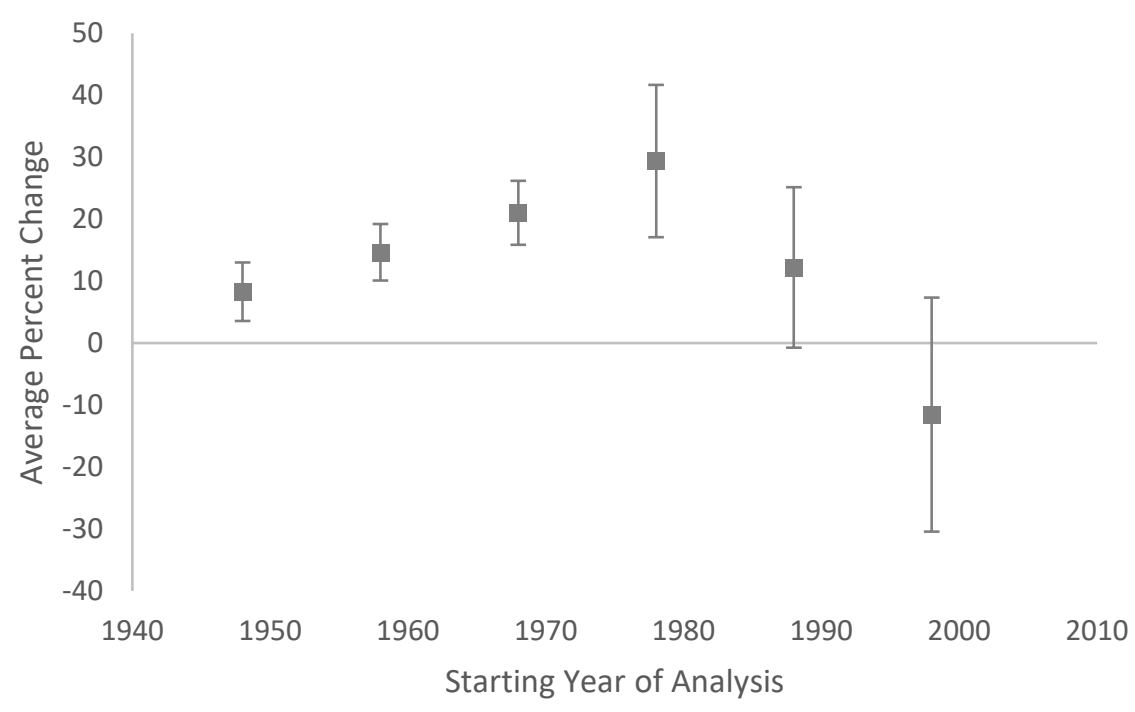

Figure 14: Average percent change in 100-year flow for gages in the Greenbrier watershed from (1) analysis using all years of record, to (2) analysis with given starting year, with standard deviation error bars

100-year flow was also compared for different gages based on drainage area. When 100year flows from all years of data were plotted vs. drainage area and linearly fitted, the unregulated slope $\left(47.8 \mathrm{cfs} / \mathrm{mi}^{2}\right)$ was higher than regulated slope $\left(23.5 \mathrm{cfs} / \mathrm{mi}^{2}\right)$ (Figure 15). However, when the two large drainage areas $\left(6687 \mathrm{mi}^{2}\right.$ and $\left.8371 \mathrm{mi}^{2}\right)$ associated with regulated gages were excluded, the regulated slope $\left(62.7 \mathrm{cfs} / \mathrm{mi}^{2}\right)$ rose above unregulated slope (47.8 $\mathrm{cfs} / \mathrm{mi}^{2}$ ) (Figure 16). This suggests that the two large drainage areas had a substantial impact on the shape of the trendline of the regulated gages, increasing the slope by a factor of approximately 2.7 . 


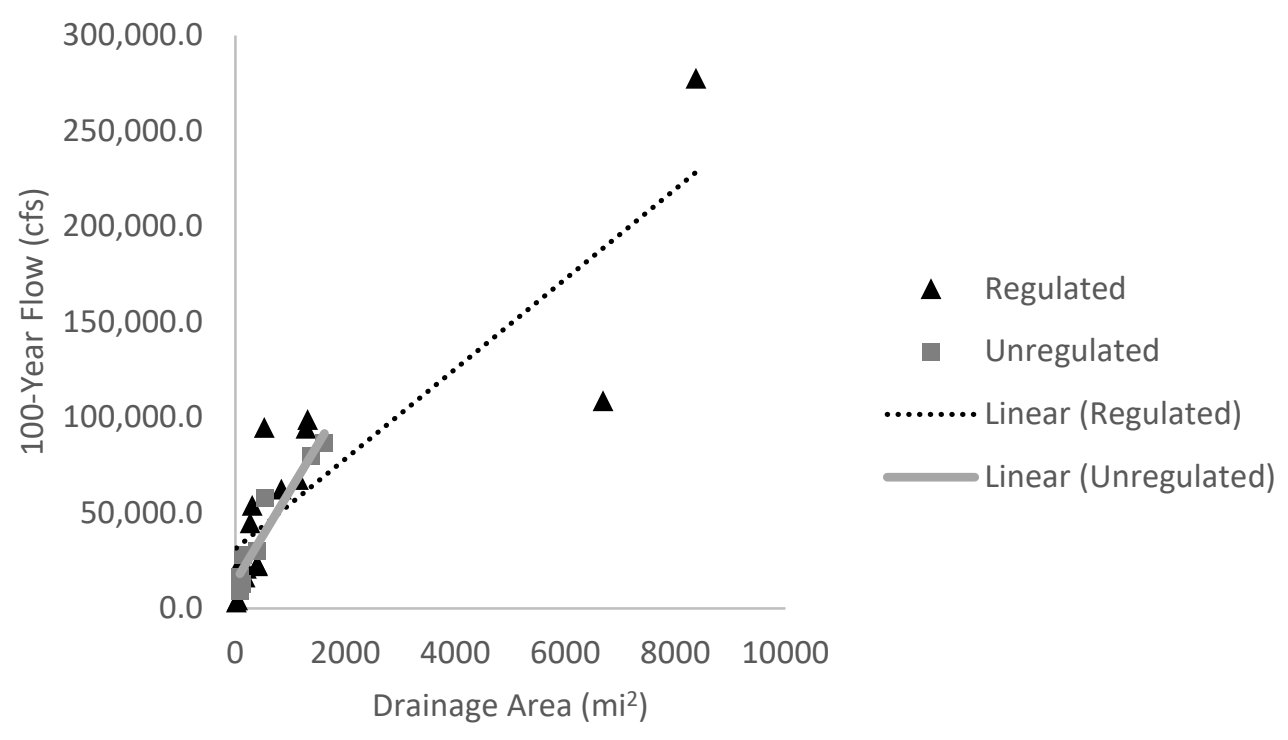

Figure 15: 100-year flow for all years of record by drainage area for regulated and unregulated gages

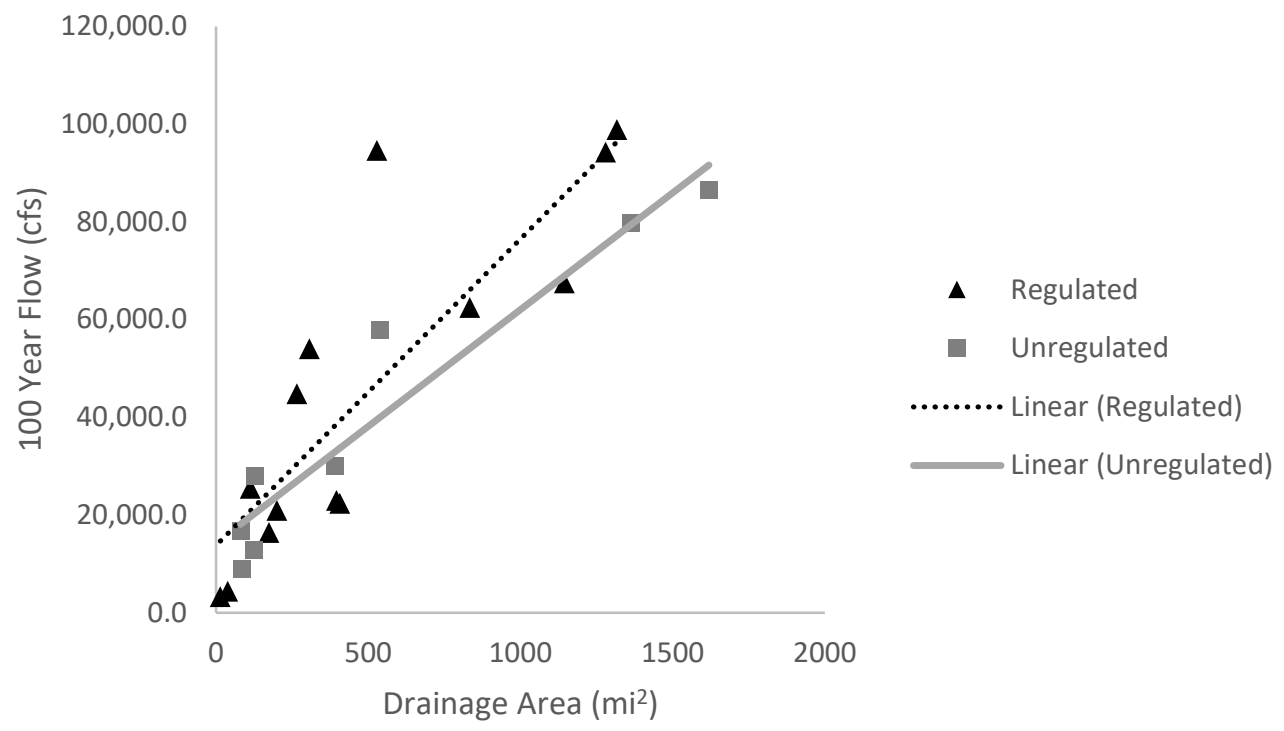

Figure 16: 100-year flow for all years of record by drainage area for regulated and unregulated gages with two large drainage areas removed

From the HEC-SSP analysis, 5\% and 95\% confidence limits are generated. These confidence limits form a confidence interval that gives the probable range of values of the 
analysis. The mean of the magnitudes of the confidence intervals for all the regulated and unregulated gages reveals that the confidence intervals tend to shrink as more years of data are used, which is expected since larger periods of record have more data points, reducing the impacts of short-term variations and outliers (Figure 17) (Chapra and Canale 2015). Also, for the 20-year analyses on the regulated gages, the standard deviation is higher than the mean by a factor of 1.15 , suggesting that these 20 -year data are distributed too widely to maintain explanatory power when combined.

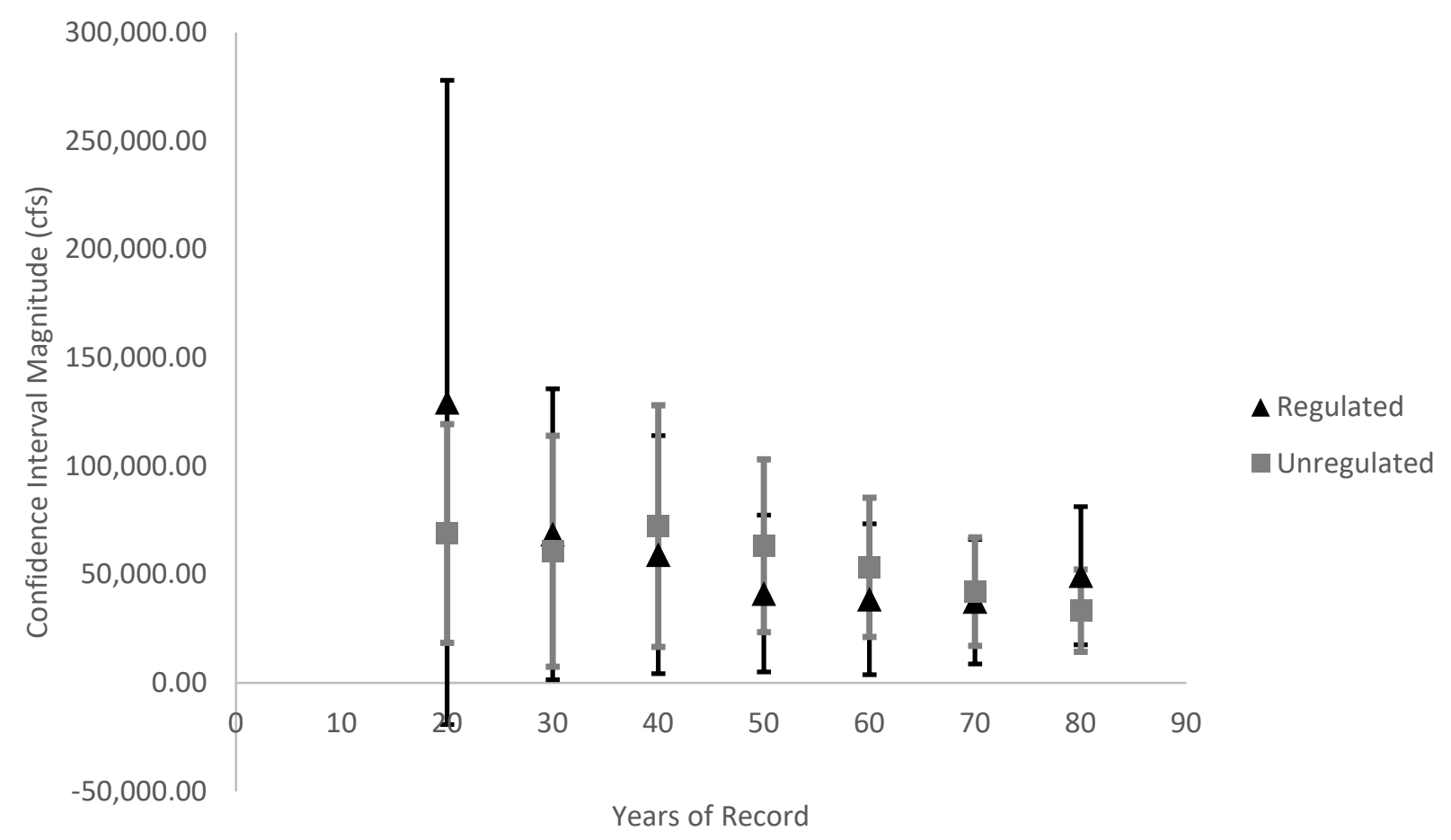

Figure 17: Mean confidence interval magnitude of 100-year flow by years of record for all regulated and unregulated gages with standard deviation error bars

From a geographical perspective, the higher 100-year flows were focused in the central and southeastern portions of the ecoregion due primarily to the streams with larger $\left(>1000 \mathrm{mi}^{2}\right)$ drainage areas (Figure 18). The lower 100-year flows were focused particularly in the northeastern area where the smaller $\left(<1000 \mathrm{mi}^{2}\right)$ drainage areas were located. 


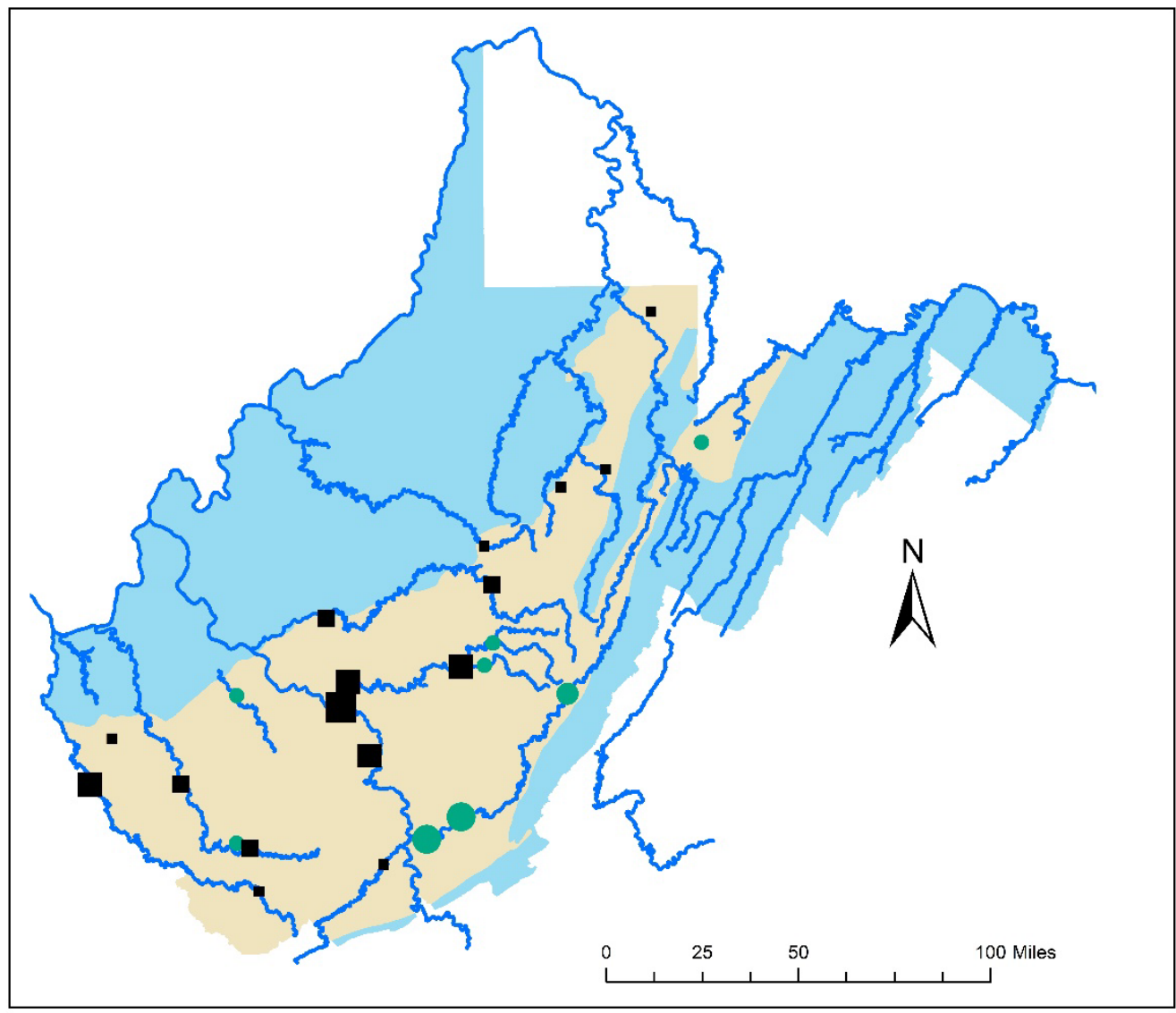

\section{Legend}

Central Appalachian Ecoregion

Streams

\section{0-Year Flow}

Regulated Gages

- $3304.2-30038.3$

— $30038.4-67548.2$

— $67548.3-108702.7$

$108702.8-277734.9$

Unregulated Gages

- $3304.2-30038.3$

- $30038.4-67548.2$

- $67548.3-108702.7$

$108702.8-277734.9$

Figure 18: Map of regulated and unregulated gage stations with magnitude of 100-year flow indicated by size of symbology

When percent change in 100-year flow was mapped, the westernmost 80 miles of the ecoregion experienced the most substantial decreases in 100-year flow over the years, while the largest increases were seen in the southern and northern portions of the ecoregion (Figure 19). 


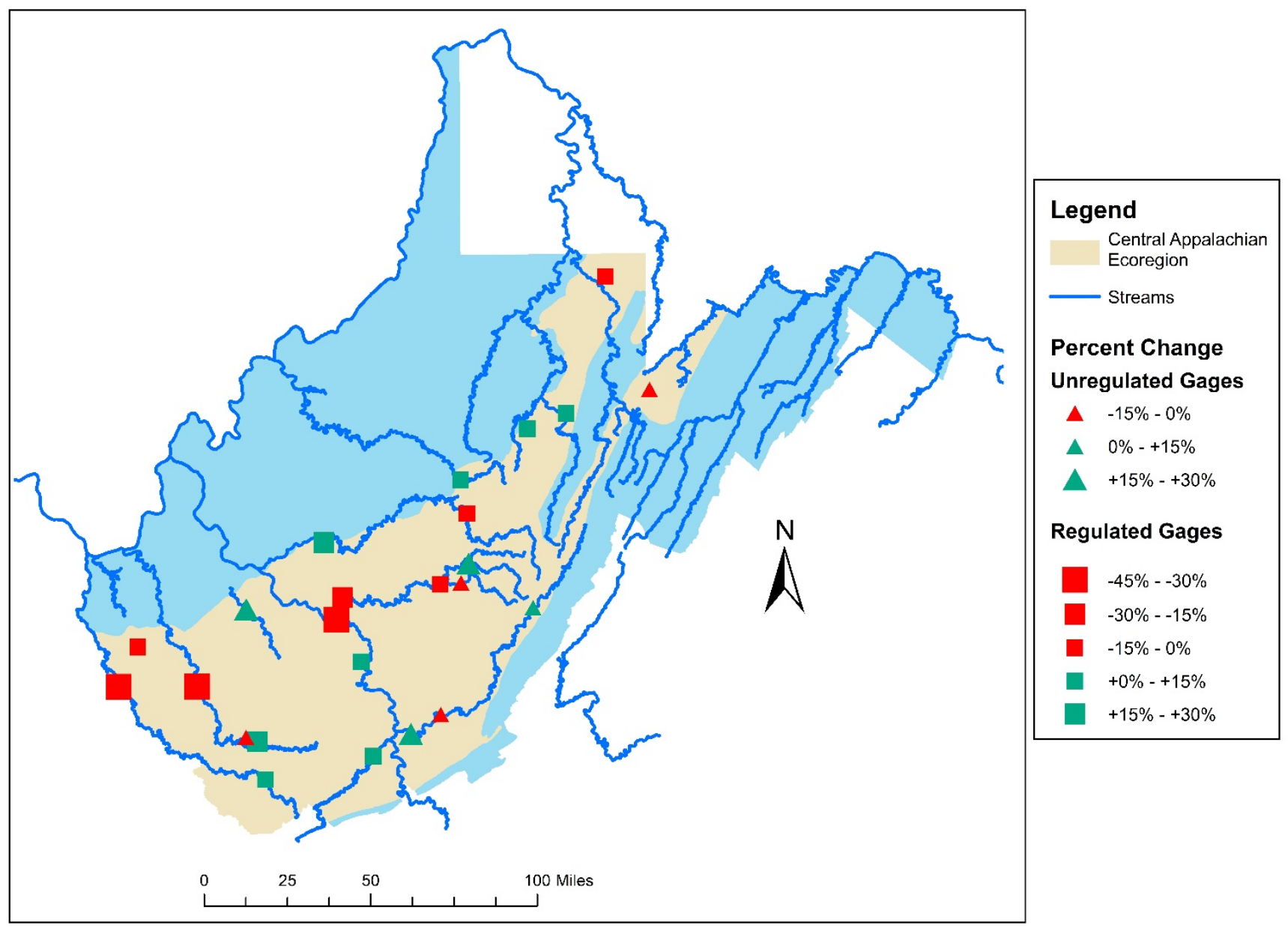

Figure 19: Map of regulated and unregulated gage stations with percent change in 100-year flow from all-year analysis to 30-year analysis indicated by color and size of symbology

\subsection{Reservoir routing}

The results from the reservoir routing analysis yielded peak outflows for each type of scenario: ESW crest, ESW design storm, and dam overtopping. The peak outflow was identified and applied to the corresponding flow equation to calculate the peak elevation of the scenario. For the more complicated equations (Equations 6 and 7), the Newton-Raphson method (Chapra and Canale 2015) was used with R coding to find an approximate solution for elevation given flow, and these solutions were checked by applying the newfound elevation to the equation to check that it matched the original outflow (R Core Team 2017) (Gilbert and Varadhan 2016) (Schlegel 2017). To be sure of the accuracy of the outflow, the flow volumes under the inflow 
curve and outflow curve were calculated and compared, as they should be equal. The inflow volume was calculated with a simple triangle equation, and the outflow volume was calculated with the trapezoidal rule.

The scenarios that will be used in the second task were drawn from the 100-year flow data results. The following are justifications for each scenario:

1. (-7\%): Change from all years of data included to 30 years of data included for all regulated gages

2. $(+6 \%)$ : Change from all years of data included to 30 years of data included for all unregulated gages

3. $(+12 \%)$ : Change from all years of data included to 30 years of data included for only gages in the Greenbrier watershed

4. $(+20 \%)$ : Change from all years of data included to 40 years of data included for all unregulated gages

5. (+30\%): Change from all years of data included to 40 years of data included for only gages in the Greenbrier watershed

For each relevant gage, these scenarios were matched with the new corresponding frequency storm using the frequency plots from HEC-SSP (USACE 2018a). Then the range of frequency storms was found for each scenario (Table 6). For example, since the $-7 \%$ scenario was based on regulated gage results, the new frequency storm range was found using all the frequency plots of the regulated gages.

Table 6: Frequency storms corresponding to percent change scenarios

\begin{tabular}{|l|l|l|l|l|l|}
\hline Scenario & $-7 \%$ & $+6 \%$ & $+12 \%$ & $+20 \%$ & $+30 \%$ \\
\hline Frequency Storm (yr) & 35 to 82 & 125 to 229 & 127 to 256 & 204 to $>500$ & 177 to $>500$ \\
\hline
\end{tabular}

\subsubsection{ESW crest}

The ESW crest was reached at around an $11.68 \%$ increase in peak inflow from the peak inflow given in the design report (Figure 20). The ESW crest is designed to 100-year flow, so the peak inflow from the design report matches the 100-year flow at the time of construction. 
With the analysis of this research, the peak inflow to reach the ESW crest is calculated to be around $11.68 \%$ higher than in the design report.

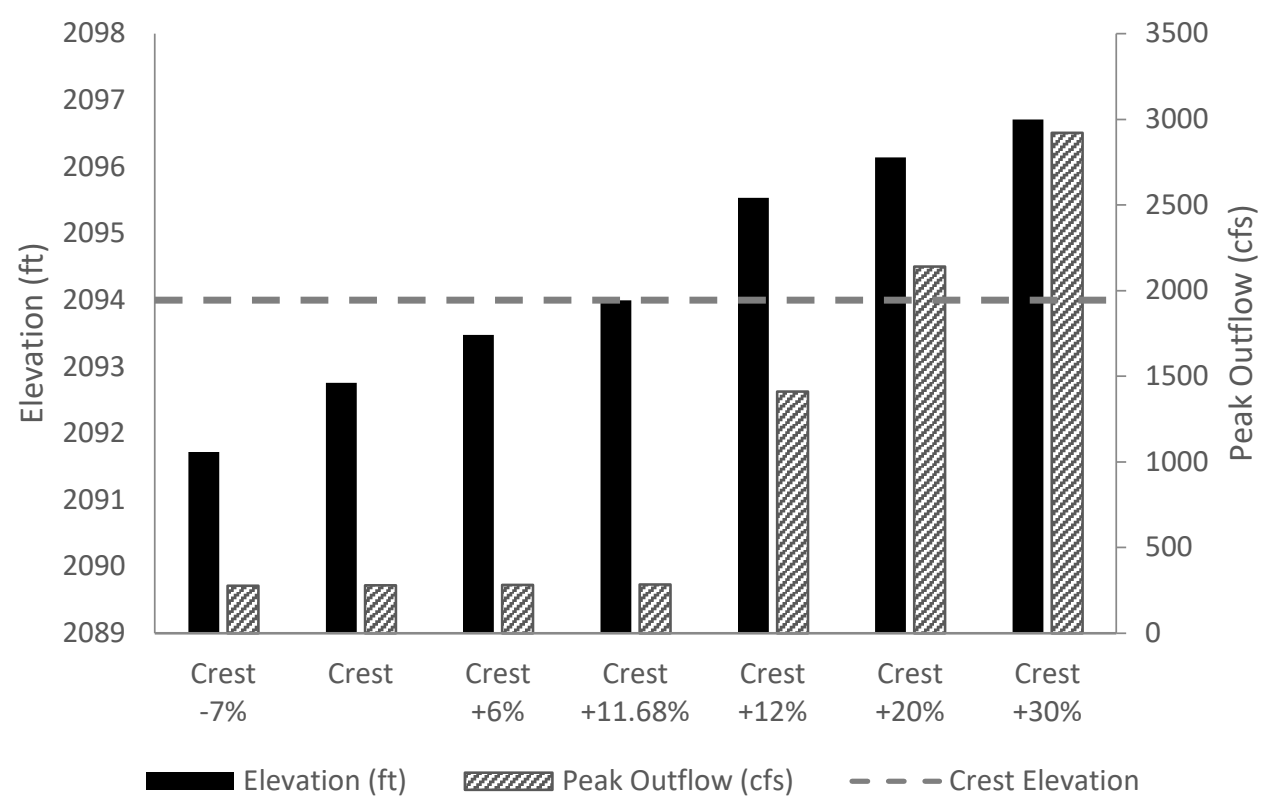

Figure 20: Peak outflow and peak elevation for crest of ESW scenarios with oval indicating where peak outflow reaches crest of ESW

\subsubsection{ESW design storm}

As expected, the ESW design storm scenarios are all over the crest of the ESW, but below the dam crest (Figure 21). However, the scenarios are based on increases in 100-year flow, and the ESW design storm is calculated using both 100-year flow and PMP. 


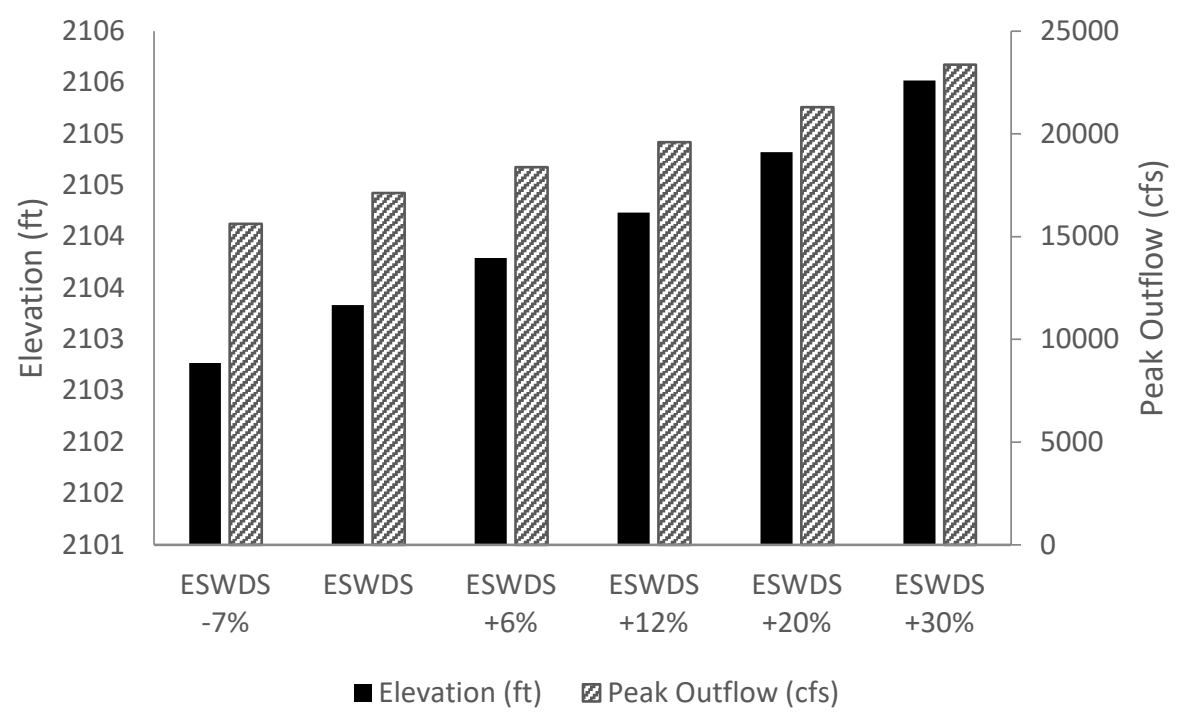

Figure 21: Peak outflow and peak elevation for ESW design storm scenarios

\subsubsection{Dam overtopping}

The dam overtopping was actually found to occur at around $9.579 \%$ smaller peak inflow than the design report predicted (Figure 22). Importantly, however, the scenarios are based on increases in 100-year flow, and dam overtopping design values are calculated with PMP.

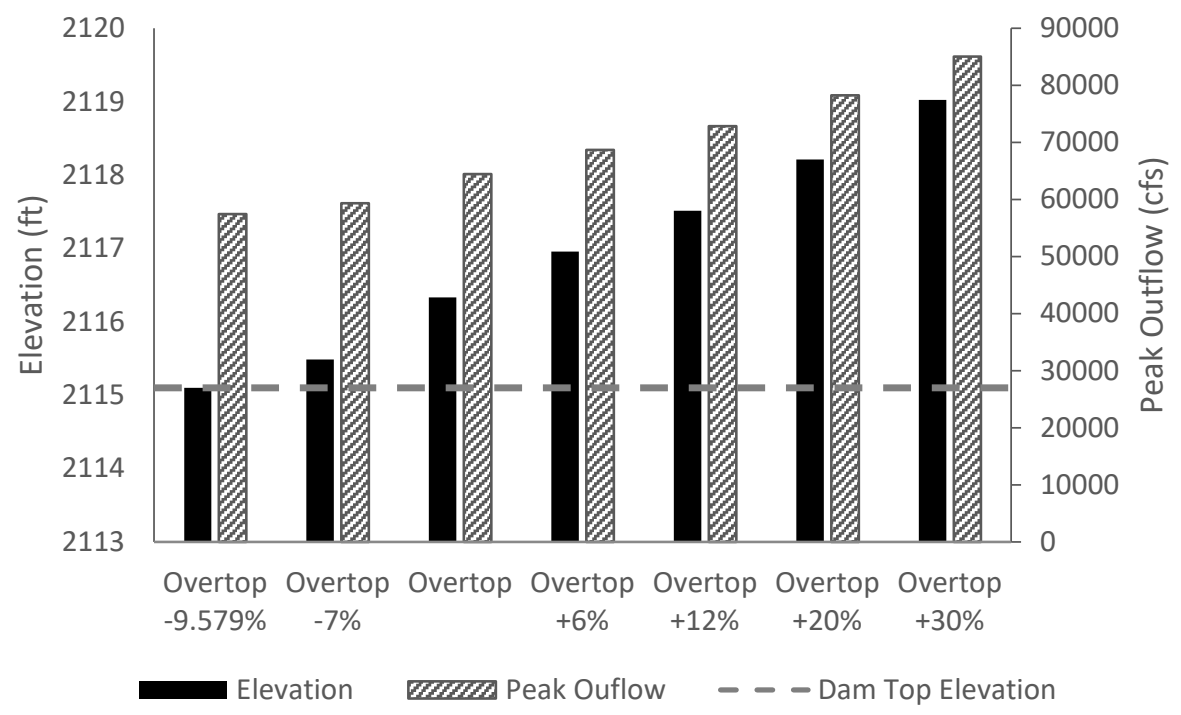

Figure 22: Peak outflow and peak elevation for dam overtopping scenarios with oval indicating where peak outflow reaches dam crest 


\subsubsection{Routing Results}

The comprehensive table of the scenario results gives the following for each scenario: peak inflow, peak outflow, equation used for outflow, maximum head, maximum elevation, inflow area, outflow area, and notes where water reached a notable elevation (Table 6).

Table 7: Outcomes of reservoir routing analysis

\begin{tabular}{|c|c|c|c|c|c|c|c|}
\hline Scenario & $\begin{array}{l}\text { Peak } \\
\text { Inflow } \\
\text { (cfs) }\end{array}$ & $\begin{array}{l}\text { Peak } \\
\text { Outflow } \\
\text { (cfs) }\end{array}$ & Equation & $\begin{array}{l}\text { Max } \\
\text { Head } \\
\text { (ft) } \\
\end{array}$ & $\begin{array}{l}\text { Max } \\
\text { Elevation } \\
\text { (ft) } \\
\end{array}$ & $\begin{array}{l}\text { Inflow } \\
\text { Volume } \\
\text { (cfs-hr) }\end{array}$ & $\begin{array}{l}\text { Outflow } \\
\text { Volume } \\
\text { (cfs-hr) }\end{array}$ \\
\hline & $\begin{array}{c}\text { AT 3.8 } \\
\text { HRS }\end{array}$ & & & & & & \\
\hline Crest - $7 \%$ & 5225 & 279 & 5 & 28.72 & 2091.72 & 26506.4 & 26508.3 \\
\hline Crest & 5618 & 281 & 5 & 29.76 & 2092.76 & 28500.1 & 28503.6 \\
\hline Crest $+6 \%$ & 5955 & 283 & 5 & 30.48 & 2093.48 & 30209.7 & 30213.8 \\
\hline $\begin{array}{l}\text { Crest } \\
+\mathbf{1 1 . 6 8 \%}\end{array}$ & 6274 & 284 & 5 & 31.00 & 2094.00 & 31828.5 & 31832.3 \\
\hline Crest $+12 \%$ & 6292 & 1411 & 6 & 32.54 & 2095.54 & 31920.1 & 31924.0 \\
\hline Crest $+20 \%$ & 6742 & 2141 & 6 & 33.14 & 2096.14 & 34202.2 & 34204.3 \\
\hline Crest $+30 \%$ & 7303 & 2921 & 6 & 33.71 & 2096.71 & 37048.1 & 37054.7 \\
\hline & $\begin{array}{c}\text { AT 3.8 } \\
\text { HRS }\end{array}$ & & & & & & \\
\hline $\begin{array}{l}\text { ESW Design } \\
\text { Storm }\end{array}$ & 20387 & 17118 & 6 & 40.33 & 2103.33 & 103423.3 & 103435.8 \\
\hline ESWDS -7\% & 18960 & 15616 & 6 & 39.77 & 2102.77 & 96184.1 & 96195.3 \\
\hline ESWDS $+6 \%$ & 21610 & 18373 & 6 & 40.79 & 2103.79 & 109627.5 & 109642.0 \\
\hline ESWDS $+12 \%$ & 22833 & 19604 & 6 & 41.23 & 2104.23 & 115831.8 & 115848.1 \\
\hline ESWDS $+20 \%$ & 24464 & 21298 & 6 & 41.82 & 2104.82 & 124105.9 & 124123.0 \\
\hline ESWDS $+30 \%$ & 26503 & 23361 & 6 & 42.52 & 2105.52 & 134449.7 & 134466.6 \\
\hline & $\begin{array}{c}\text { AT 3.7 } \\
\text { HRS }\end{array}$ & & & & & & \\
\hline $\begin{array}{l}\text { Dam Overtop } \\
-9.579 \% \\
\end{array}$ & 61417 & 57470 & 6 & 52.10 & .10 & 303368.8 & 303377.0 \\
\hline $\begin{array}{l}\text { Dam Overtop } \\
-7 \%\end{array}$ & 63168 & 59371 & 7 & 52.48 & 2115.48 & 312020.3 & 312028.7 \\
\hline Dam Overtop & 67923 & 64482 & 7 & 53.33 & 2116.33 & 335505.7 & 335514.8 \\
\hline $\begin{array}{l}\text { Dam Overtop } \\
+6 \%\end{array}$ & 71998 & 68709 & 7 & 53.96 & 6.96 & 355636.0 & 355645.6 \\
\hline $\begin{array}{l}\text { Dam Overtop } \\
+12 \%\end{array}$ & 76074 & 72818 & 7 & 54.52 & 2117.52 & 375766.3 & 375776.5 \\
\hline $\begin{array}{l}\text { Dam Overtop } \\
+20 \%\end{array}$ & 81508 & 78233 & 7 & 55.21 & 2118.21 & 402606.8 & 402617.7 \\
\hline $\begin{array}{l}\text { Dam Overtop } \\
+30 \%\end{array}$ & 88300 & 85033 & 7 & 56.03 & 2119.03 & 436157.4 & 436169.2 \\
\hline
\end{tabular}




\section{Discussion}

It is important to note that the analyses performed at all stages of this research used only past data, and no predictive models for the future. The scenarios for change in peak inflows to the dam were based on 100-year flow results, so they might not apply directly to ESW design storm and dam crest. The ESW design storm is partially based on PMP and dam overtopping is based solely on PMP. Any of the 432 high hazard dams in West Virginia could be affected by the changes in 100-year flow over time, but it will likely depend on the specifications of a particular dam and the watershed characteristics (USACE 2018b). Some dams have changed to high hazard from a lower hazard category because of developments downstream of the dam, and these developments could have also affected the peakflow levels from the gages in those streams

The reason both unregulated and regulated streams were analyzed was that urban development and dams can have a strong impact on the occurrence of floods, and flow data after a large-scale human change may be completely different than flow data before a change (USGS 2018). Regulated streams have dams to control the flowrates through the streams and lower peakflows for flood control (Bedient et al. 2013). The results of this research support the expected effects of stream regulation because regulated streams have experienced a decreased 100-year flow over time. Conversely, unregulated streams have experienced an increase in 100year flow over time, likely due to climate change effects.

Only changes in 100-year storm magnitude were considered, but there is evidence of increases in frequency of 100-year storms as well. The increase in frequency of these storms in the region was not considered. In the 2000 s, the frequency of extreme precipitation events was higher than any previous decade on record (Frei et al. 2015). Also, the southern Appalachians and Ohio River Valley are expected to experience 2-5 times more 100-year floods by 2100 (Wobus et al. 2017).

The dam overtopping scenarios, calculated from the weir equation over the crest of the dam, predict that the dam crest elevation would be reached by about a $-9.6 \%$ change from the given flow from the design report. This would indicate that the dam crest elevation would be reached with a much lower flow than that predicted by the design report. However, the methods used in the design report were from PMP, and the methods used in the scenarios in this research were based on a weir equation from average dam length. Possible problems with the research methods include errors in measurement of dam length or an equation that oversimplifies the 
physics of dam overtopping. This research also did not consider the heights of flood waves or freeboard, only the rise in elevation of the reservoir. Recently, an assessment report of the dam described the crest of the dam as a "non-level crest that varies from elevation 2115.9 to 2119.7 $\mathrm{ft}$ " rather than the design elevation of $2115.1 \mathrm{ft}$ due to "less settlement than predicted" (NRCS 2016a).

Differences in regulation strategies between dams of different organizations such as USGS, NRCS, or private ownership could affect how flow through those dams is regulated, which would affect the results from the regulated gages in the analysis of this research. Also, the order in which dam reservoirs are drained would also influence the peakflows through the gages in those streams. These variations between dams are influenced by both the management strategies of different dams and the state of repair of those dams. The flows through dams that are determined to be fragile may be controlled to reduce the stresses on those dams, instead placing stress on more resilient dams. 


\section{Summary and Conclusions}

The goal of this research was to determine if dam design criteria for high hazard dam emergency spillways remain adequate despite changing climate with increased extreme precipitation events. To measure climate change effects, the 100-year flow was calculated for 24 USGS gages in the CAE in WV using HEC-SSP, and several scenarios were generated with this 100-year flow data to be used to analyze flow through the emergency spillway of Howard Creek Dam. The central finding of the research were the following:

- The 100-year flow for regulated gages has decreased over time, indicating that installation of dams and subsequent regulation of flow through the dams has lowered the peakflows of those gages.

- The 100-year flow for unregulated gages has increased over time, indicating that without dams on the stream, climate change has caused higher peakflows due to higher frequencies and magnitudes of extreme precipitation events.

- The emergency spillway of Howard Creek Dam was predicted to be reached by an $11.68 \%$ increase in 100-year flow from the value given in the design report of the dam. This $11.68 \%$ increase is exceeded by the three of the generated scenarios: the $12 \%$ increase, the $20 \%$ increase, and the $30 \%$ increase. The $12 \%$ and $30 \%$ scenarios were generated from Greenbrier watershed gage data, and the $20 \%$ scenarios was generated with CAE unregulated gage data. As a result, an $11.68 \%$ increase in 100 -year flow does seem feasible within the next several decades, so emergency spillway designs should factor in potential increases in 100-year flow.

Future work could include a predictive model including how 100-year flow is expected to change in the coming years rather than just analysis of past data. Also, to fully describe the behavior for the emergency spillway design storm and dam overtopping scenarios, calculations involving PMP should be included. A more specific analysis could be performed on which dams in the region would be affected by the changes in 100-year flow. To achieve a more sophisticated model, research could account for increase in storm frequency, flow equations accounting for specific dam profiles, dam operation differences, dams from other organizations, and routing flood waves toward dams. 


\section{References}

Bedient, P.B., W.C. Huber, and B.E. Vieux (2013). Hydrology and floodplain analysis, 5th ed. Pearson: Upper Saddle River, NJ.

Chapra, Steven C., Canale, Raymond P. (2015). Numerical methods for engineers, $7^{\text {th }}$ ed. New York: McGraw-Hill Education.

Evans, Daniel M., Zipper, Carl E., Hester, Erich T., and Schoenholtz, Stephen H. (2015). "Hydrologic effects of surface coal mining in Appalachia." Journal of the American Water Resources Association, 51(5): 1436-1452.

Federal Emergency Management Agency (FEMA) (2014). "Federal guidelines for dam safety: selecting and accommodating inflow design floods for dams." U.S Department of Homeland Security.

Ferrari, J.R., T.R. Lookingbill, B. McCormick, P.A. Townsend, and K.N. Eshleman (2009). "Surface mining and reclamation effects on flood response of watersheds in the central Appalachian Plateau region." Water Resources Research, 45: W04407.

Frei, A., Kunkel, Kenneth E., and Matonse, Adao (2015). "The seasonal nature of extreme hydrological events in the northeastern United States." Journal of Hydrometeorology, 16: 20652085.

Gilbert, P. and Varadhan, R. (2016). "numDeriv: accurate numerical derivatives. R package version 2016.8-1." Documentation available at: https://CRAN.R-project.org/package=numDeriv. Accessed: February 25, 2019

Holmes, Robert R., Jr. (2017). “The 100-year flood - it's all about chance (USGS).” U.S. Geological Survey. Available at: https://water.usgs.gov/edu/100yearflood-basic.html. Accessed: February 21, 2018.

LaRocque A. (2013). "Probable maximum flood (PMF). Encyclopedia of Natural Hazards, Springer, Dordrecht.

Messinger, Terence (2003). "Comparison of storm response of streams in small, unmined and valley-filled watersheds, 1999-2001, Ballard Fork, West Virginia.” U.S Geological Survey. Available at: https://pubs.usgs.gov/wri/2002/4303/report.pdf. Accessed: April 14, 2018.

Milly, P.C.D., Wetherald R.T., Dunne, K.A., and Delworth T.L. (2002). "Increasing risk of great floods in a changing climate." Nature, 415(6871): 514-517. 
Murphy, J.C., G.M. Hornberger, and R.G. Liddle (2014). "Concentration-discharge relationships in the coal mined region of the New River Basin and Indian Fork Sub-Basin, Tennessee, USA." Hydrological Processes, 28:718-728.

Ning, L., Riddle, E.E., and Bradley, R.S. (2015). "Projected changes in climate extremes over the northeastern United States." Journal of Climate, 28: 3289-3310.

NRCS (1992a). "Design report [for Howard Creek Dam].” United States Department of Agriculture, Natural Resources Conservation Service.

NRCS (1992b). "Hydraulics and hydrology report [for Howard Creek Dam].” United States Department of Agriculture, Natural Resources Conservation Service.

NRCS (2016a). "Rehabilitation assessment report: Howard Creek site 12." United States Department of Agriculture, Natural Resources Conservation Service.

NRCS (2016b). "Watershed rehabilitation program (rehab)." United States Department of Agriculture, Natural Resources Conservation Service. Available at:

https://www.nrcs.usda.gov/wps/portal/nrcs/detail/national/programs/landscape/wr/?cid=n\rcs 143 008448. Accessed: February 20, 2018.

R Core Team (2017). "R: a language and environment for statistical computing.” R Foundation for Statistical Computing, Vienna, Austria. Available at: https://www.R-project.org/. Accessed: February 25, 2019.

Schlegel, A. (2017). "Newton-Raphson method for root-finding." Available at: https://rpubs.com/aaronsc32/newton-raphson-method. Accessed: February 25, 2019.

Tetzlaff G. and Zimmer J. (2013). "Probable maximum precipitation (PMP). Encyclopedia of Natural Hazards, Springer, Dordrecht.

USACE (2018a). “HEC-SSP Statistical Software Package User's Manual: Version 2.1.” Updated on March 29, 2018 with Bulletin 17C, "Guidelines for Determining Flood Flow Frequency."

USACE (2018b). "National Inventory of Dams interactive map and charts." Available at: https://nid-test.sec.usace.army.mil/. Accessed: March 20, 2018

USEPA (2016). "What climate change means for West Virginia." Environmental Protection Agency, 430-16-050. 
USEPA (2018). "Ecoregions." Environmental Protection Agency, Available at: https://www.epa.gov/eco-research/ecoregions. Accessed: March 20, 2019

USGS (2018). "USGS water data for the nation." U.S. Geological Survey. Available at: https://waterdata.usgs.gov/nwis. Accessed: February 25, 2018

Walsh, J., Wuebbles, D., Hayhoe, K., Kossin, J., Kunkel, K., Stephens, G., Thorne, P., Vose, R., Wehner, M., Willis, J., Anderson, D., Doney, S., Feely, R., Hennon, P., Kharin, V., Knutson, T., Landerer, F., Lenton, T., Kennedy, J., and Somerville, R. (2014). "Chapter 2: our changing climate: climate change impacts in the United States: the third national climate assessment." U.S. Global Change Research Program, 19-67.

Wobus, C., Gutmann, E., Jones, R., Rissing, M., Mizukami, N., Lorie, M., Mahoney, H., Wood, A.W., Mills, D., and Martinich, J. (2017). "Climate change impacts on flood risk and asset damages within mapped 100-year floodplains of the contiguous United States." Natural Hazards and Earth System Sciences, 17: 2199-2211.

WVDEP (2009). "Series 34: dam safety rule.” West Virginia Department of Environmental Protection. Available at: https://dep.wv.gov/oil-and-

gas/Impoundments/Documents/Impoundment\%20Refernces/Dam\%20Safety\%20Rule\%20\%2037CSR34.pdf. Accessed: February 27, 2018. 


\section{Appendix A - Relative frequency histograms}

\section{Regulated}

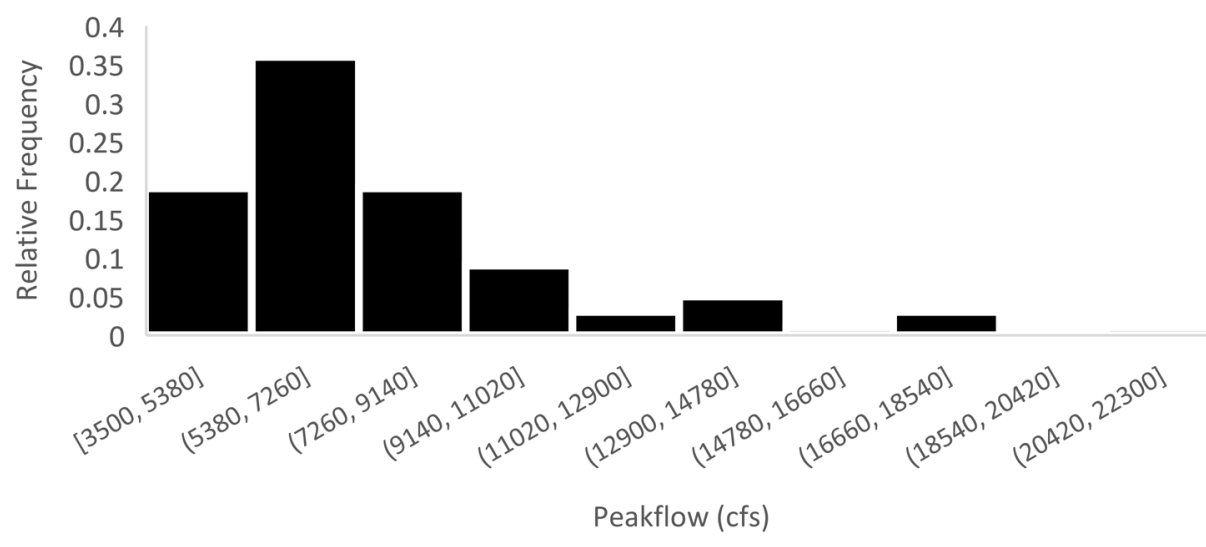

Figure 23: Relative frequency histogram for Big Sandy Creek at Rockville gage

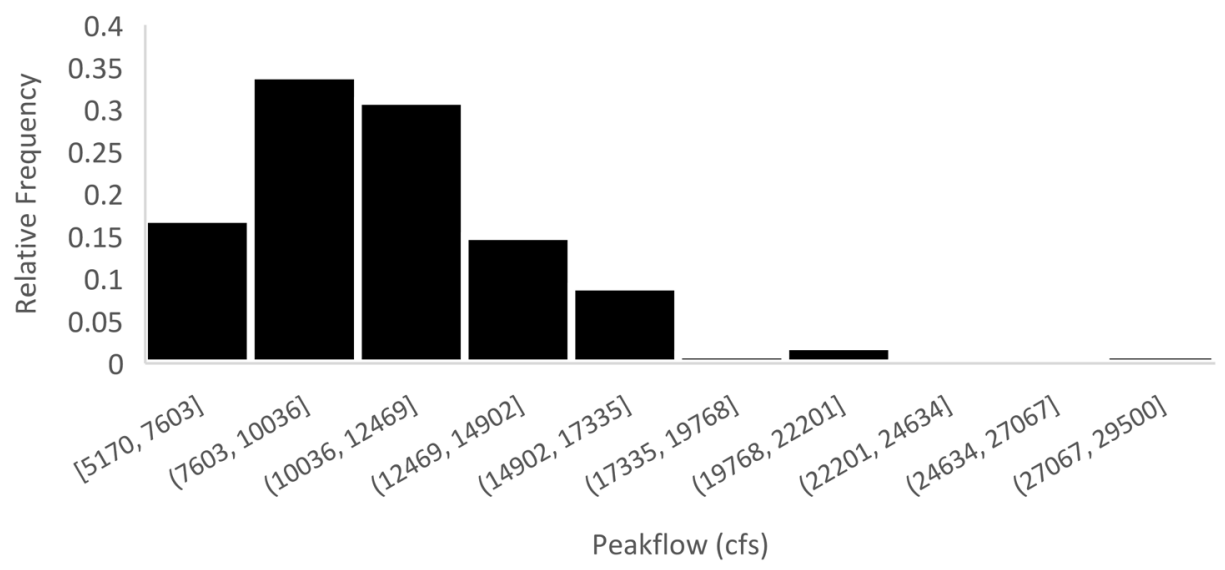

Figure 24: Relative frequency histogram for Tygart Valley River at Belington gage

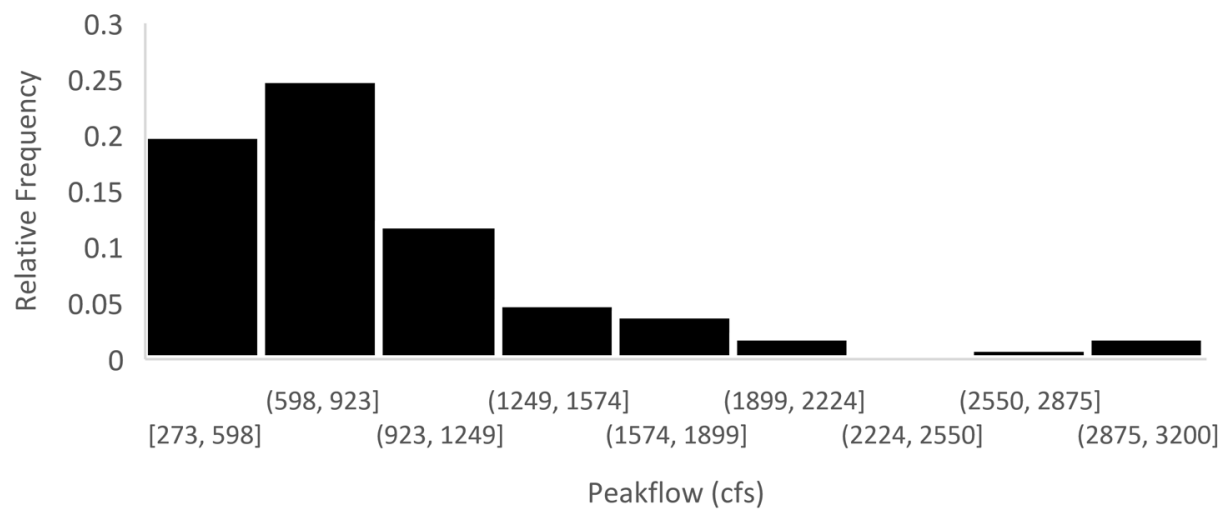

Figure 25: Relative frequency histogram for Sand Run near Buckhannon gage 


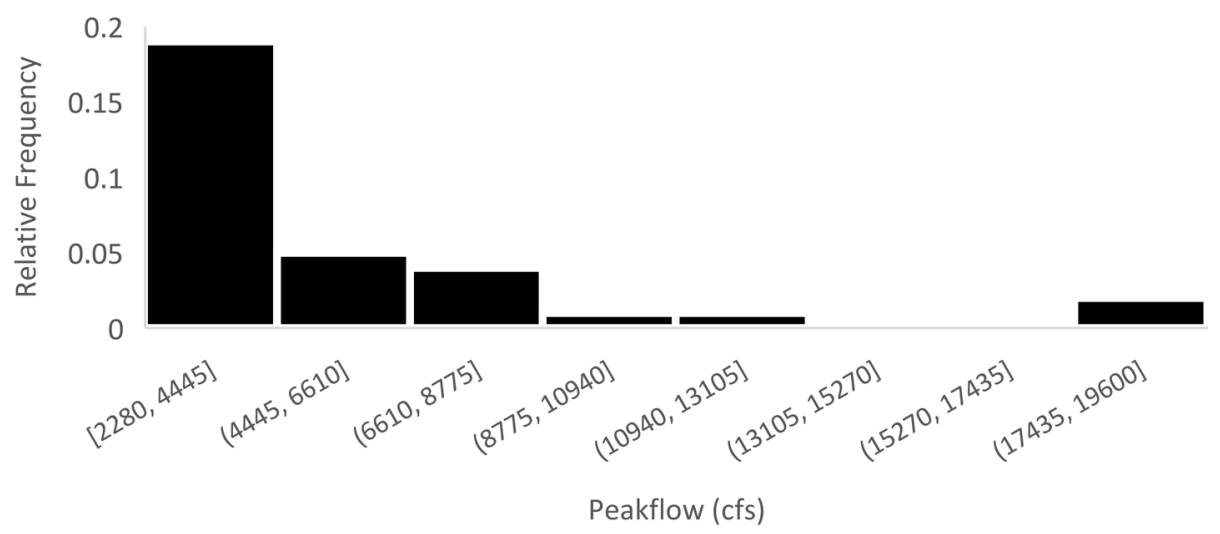

Figure 26: Relative frequency histogram for Little Kanawha River near Wildcat gage

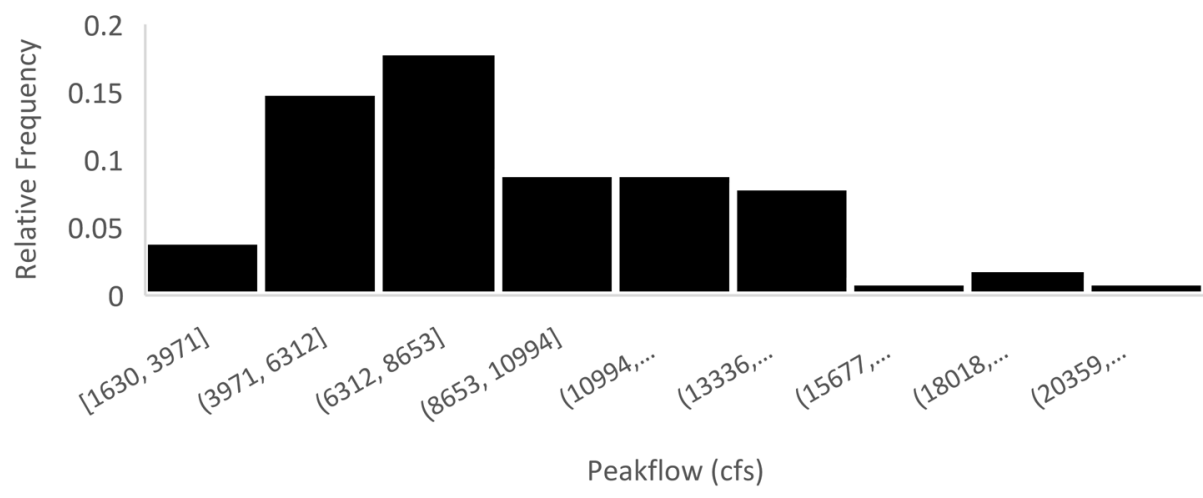

Figure 27: Relative frequency histogram for Bluestone River near Pipestem gage

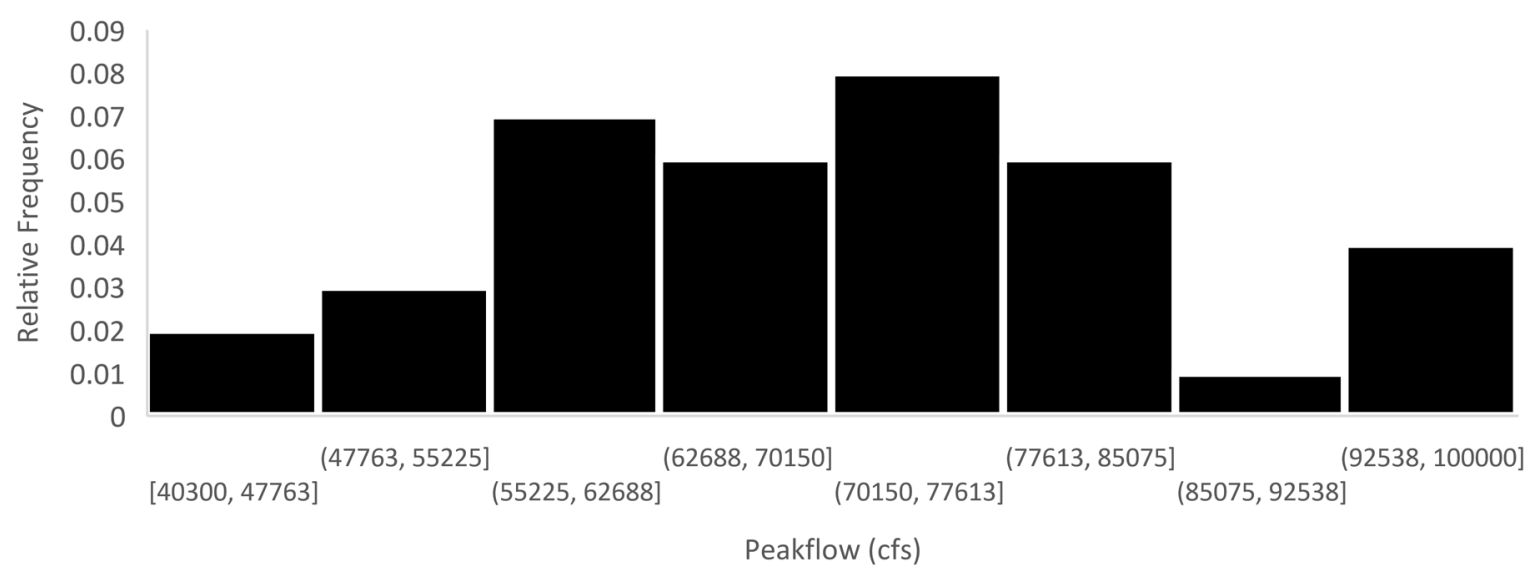

Figure 28: Relative frequency histogram for New River at Thurmond gage 


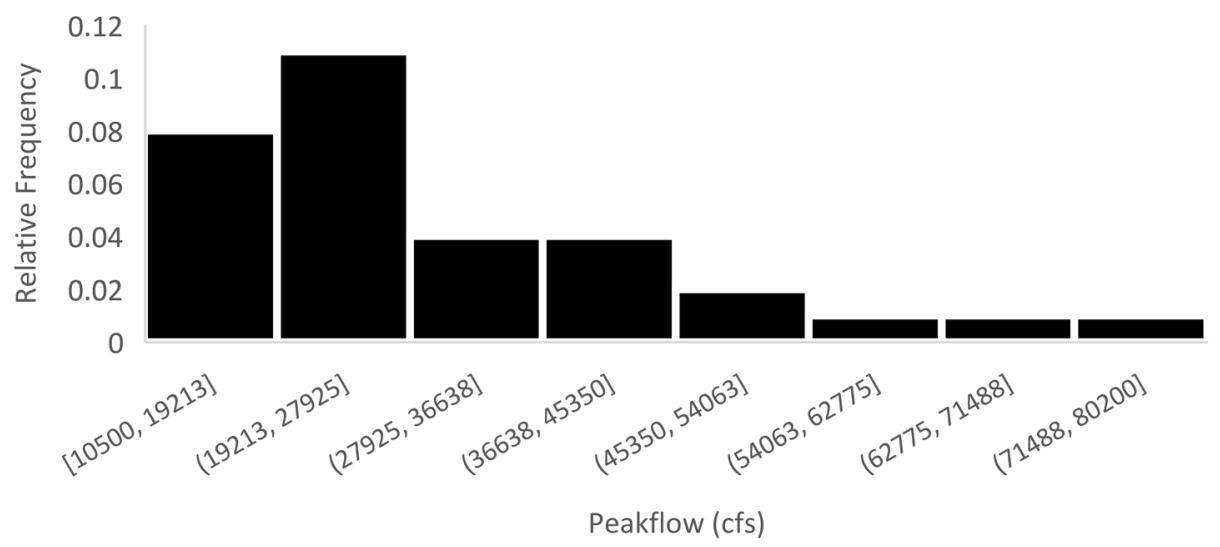

Figure 29: Relative frequency histogram for Gauley River near Craigsville gage

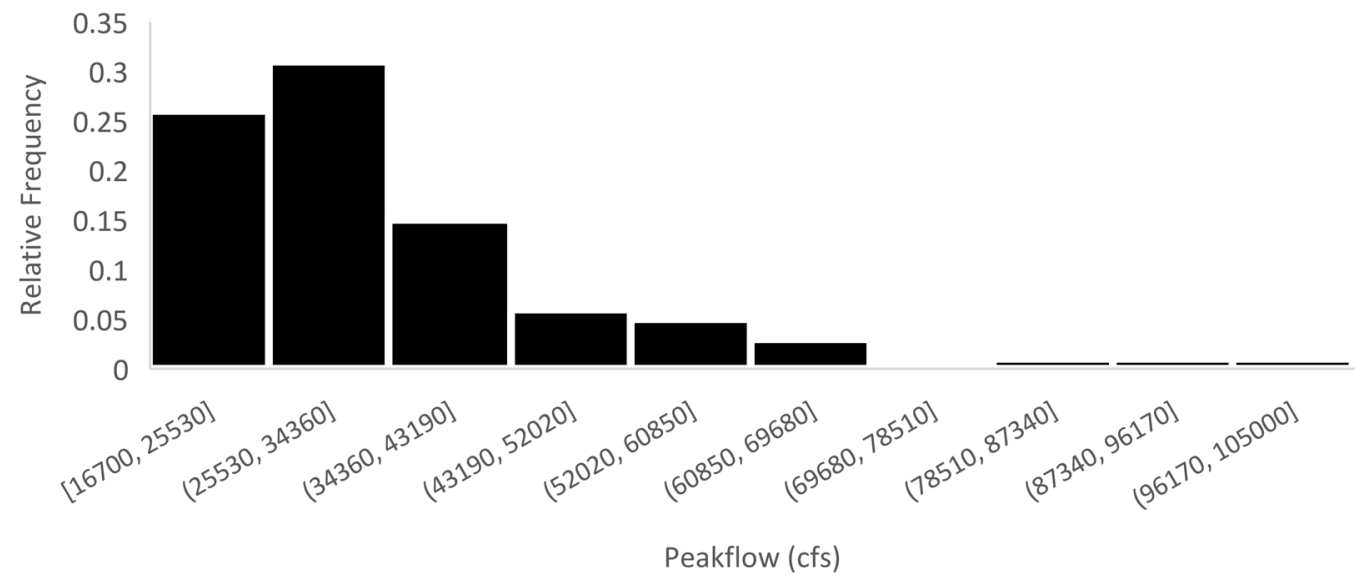

Figure 30: Relative frequency histogram for Gauley River above Belva gage

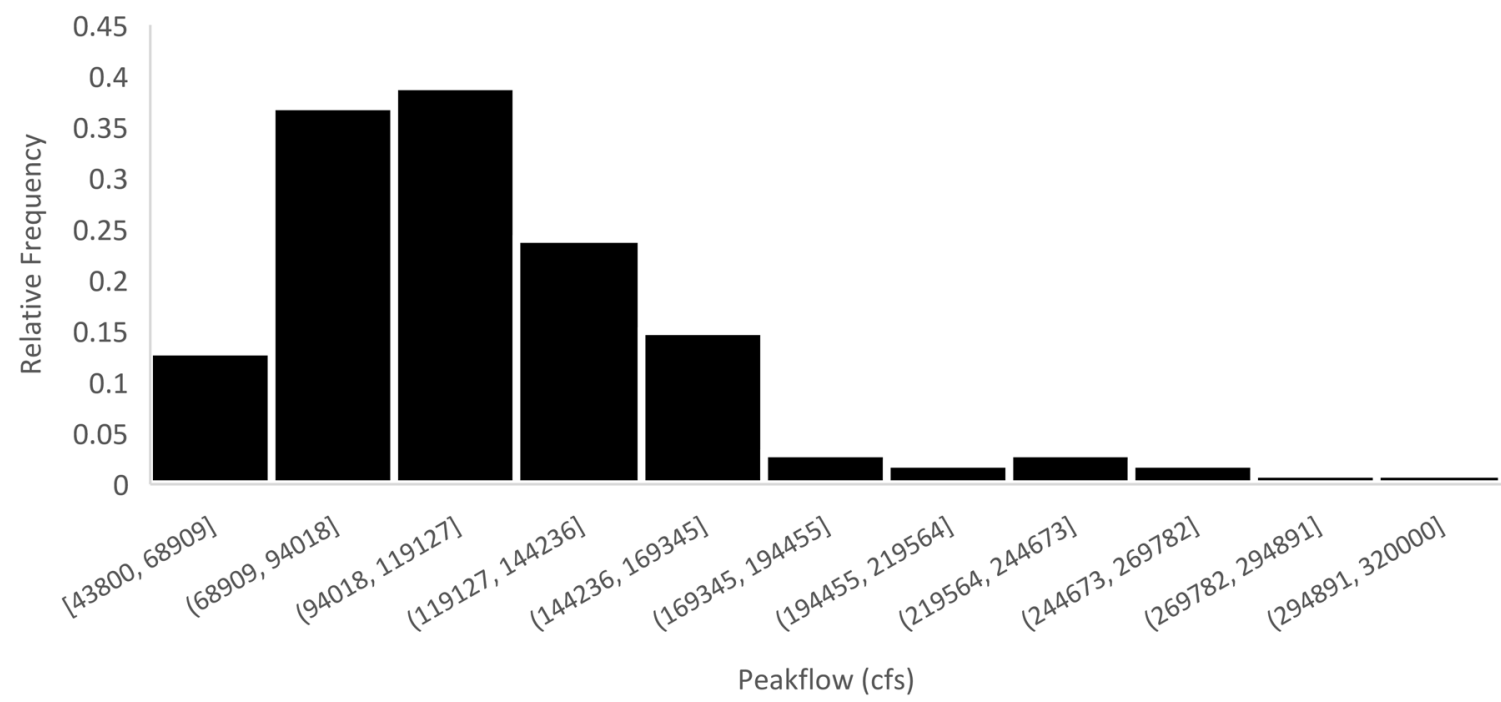

Figure 31: Relative frequency histogram for Kanawha River at Kanawha Falls gage 


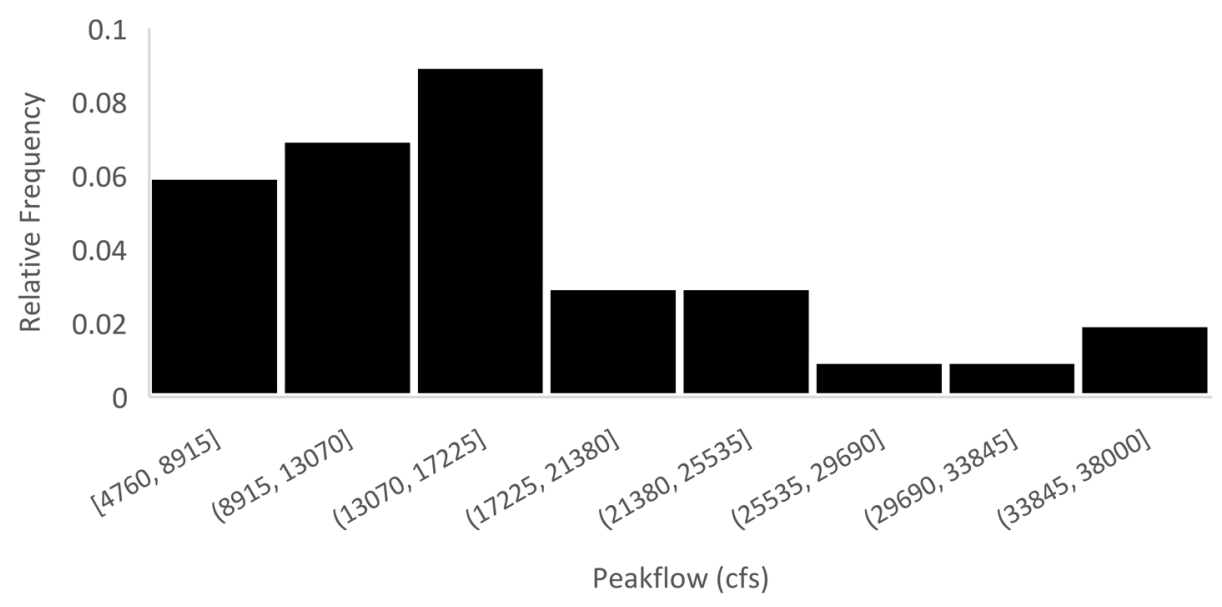

Figure 32: Relative frequency histogram for Elk River below Webster Springs gage

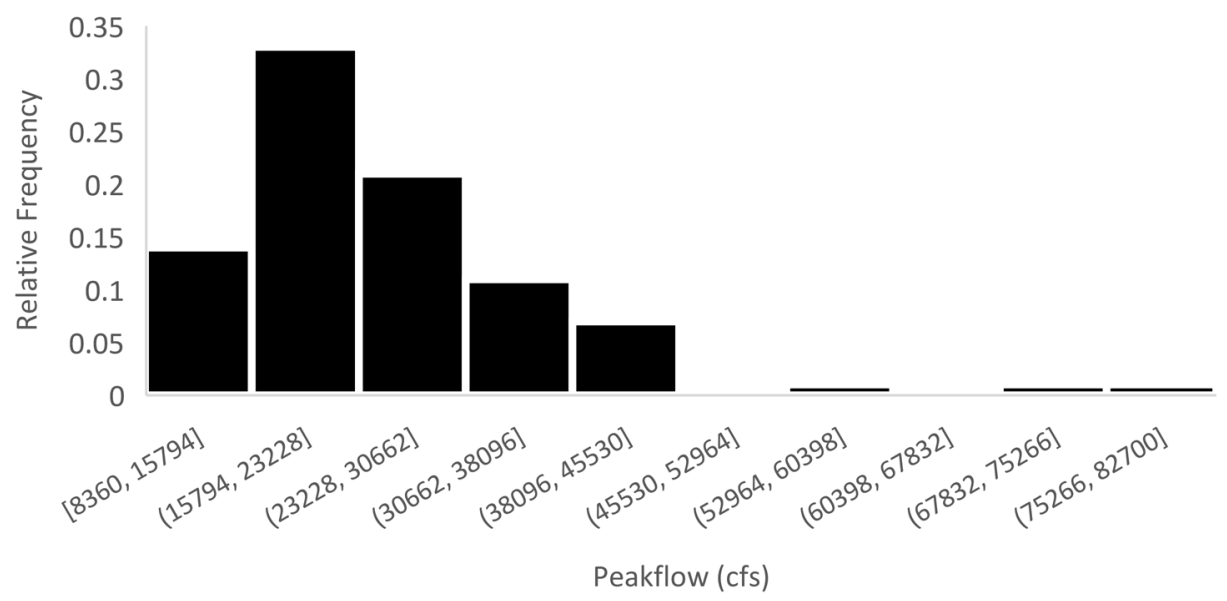

Figure 33: Relative frequency histogram for Elk River at Queen Shoals gage

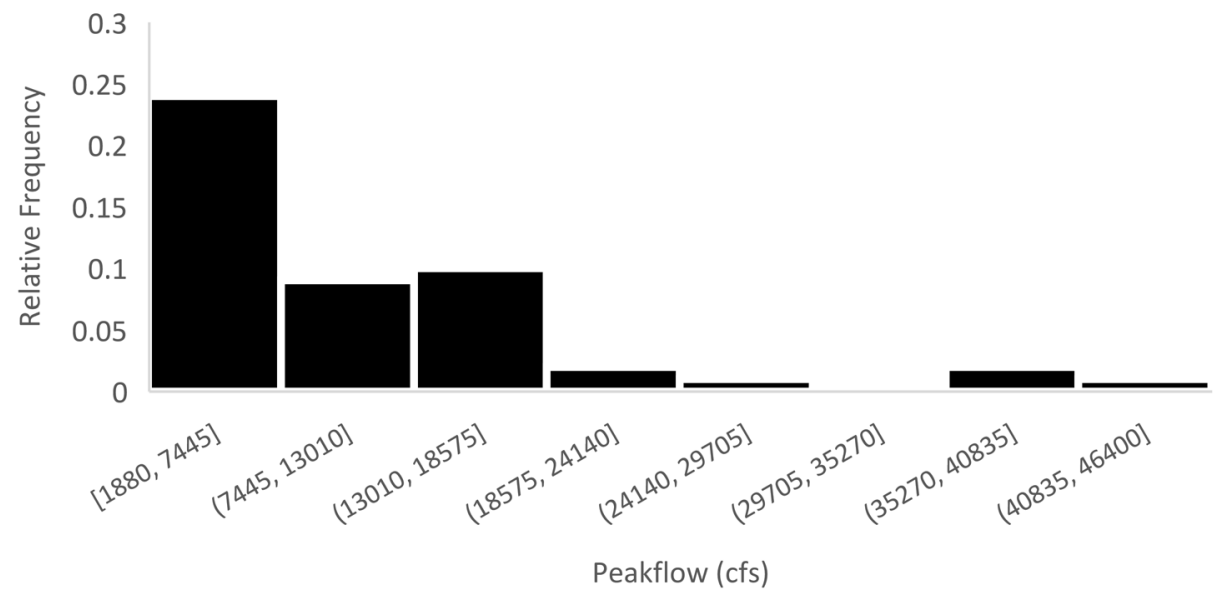

Figure 34: Relative frequency histogram for Guyandotte River near Baileysville gage 


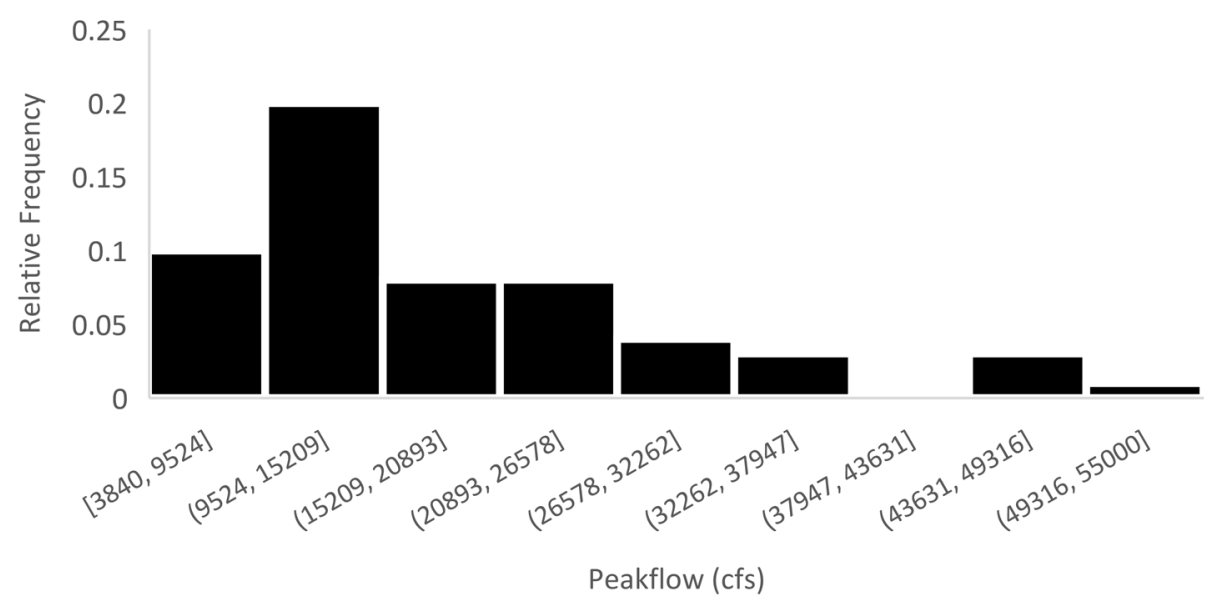

Figure 35: Relative frequency histogram for Guyandotte River at Logan gage

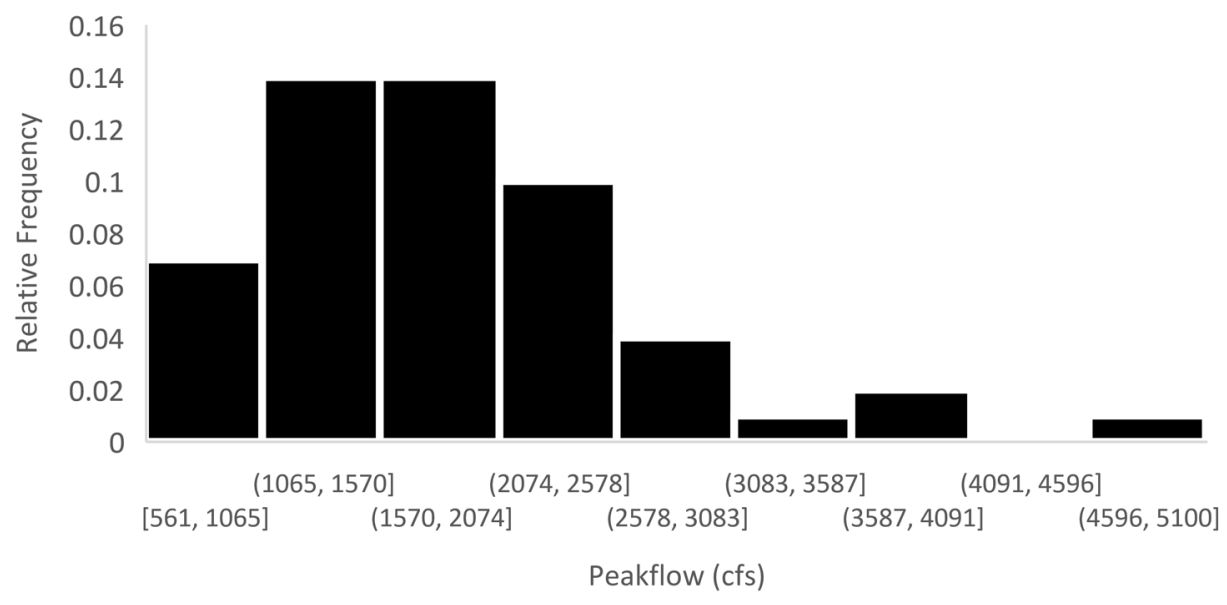

Figure 36: Relative frequency histogram for East Fork Twelvepole Creek nr Dunlow gage

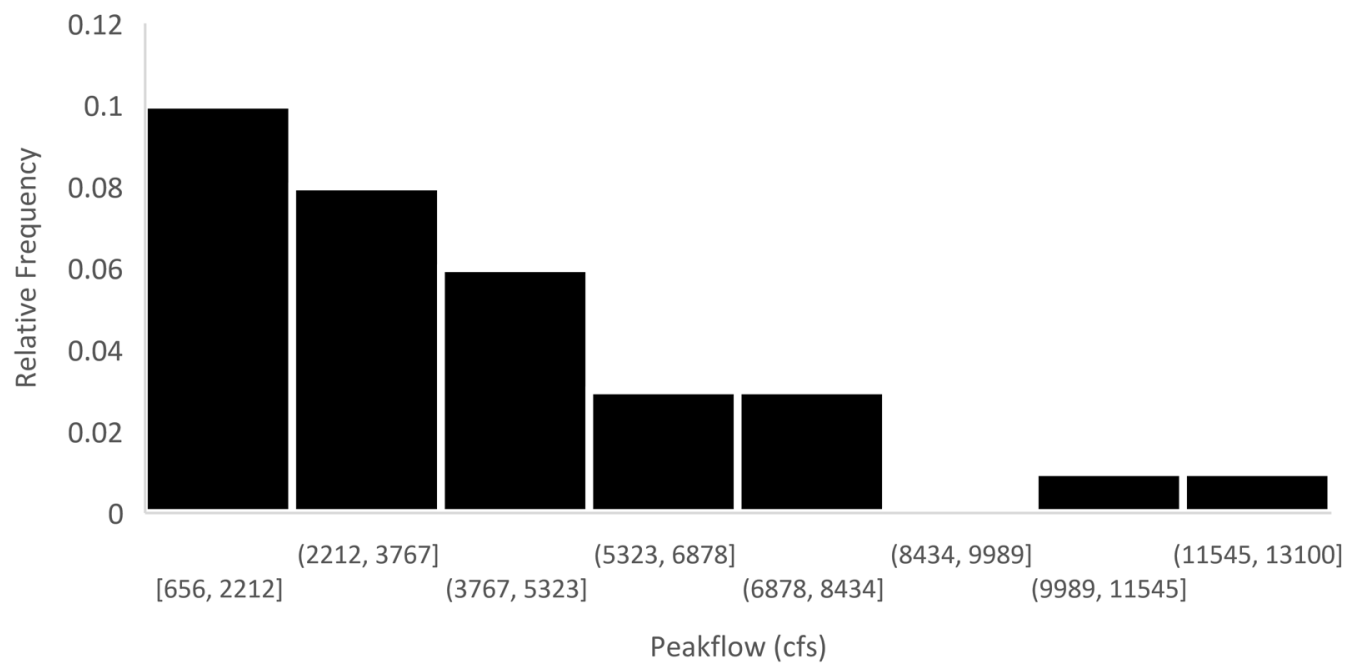

Figure 37: Relative frequency histogram for Tug Fork downstream of Elkhorn Creek at Welch gage 


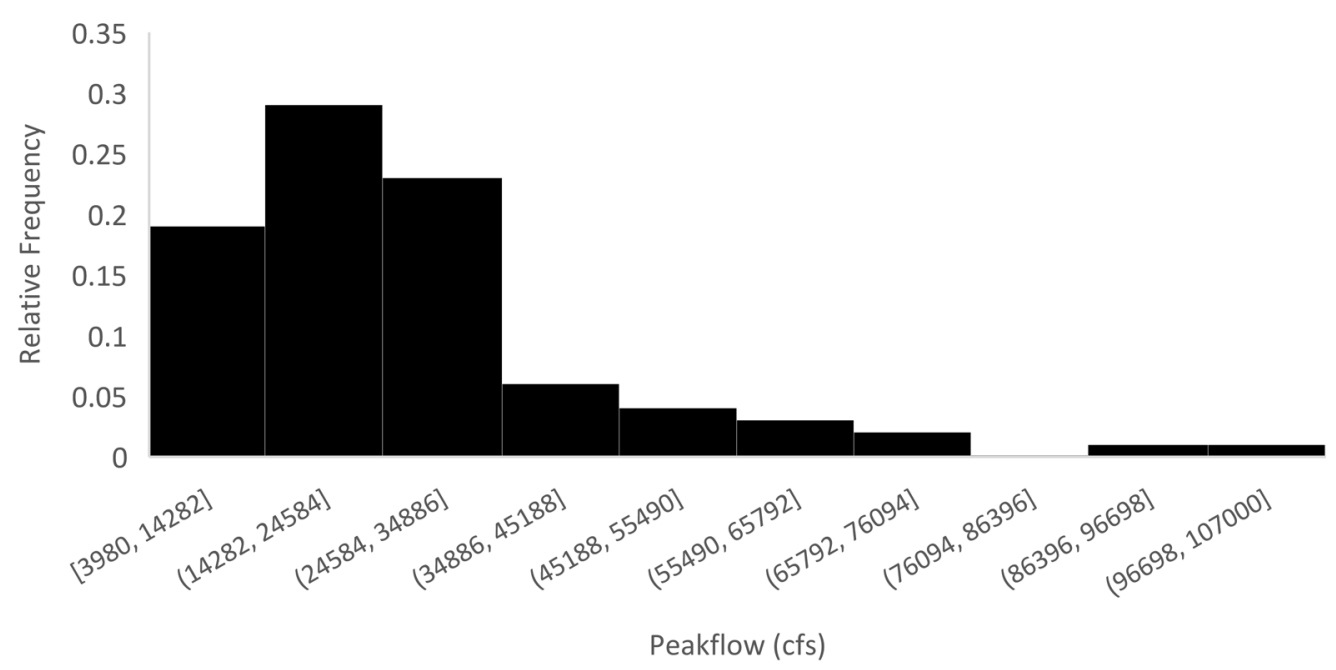

Figure 38: Relative frequency histogram for Tug Fork at Kermit gage

\section{Unregulated}

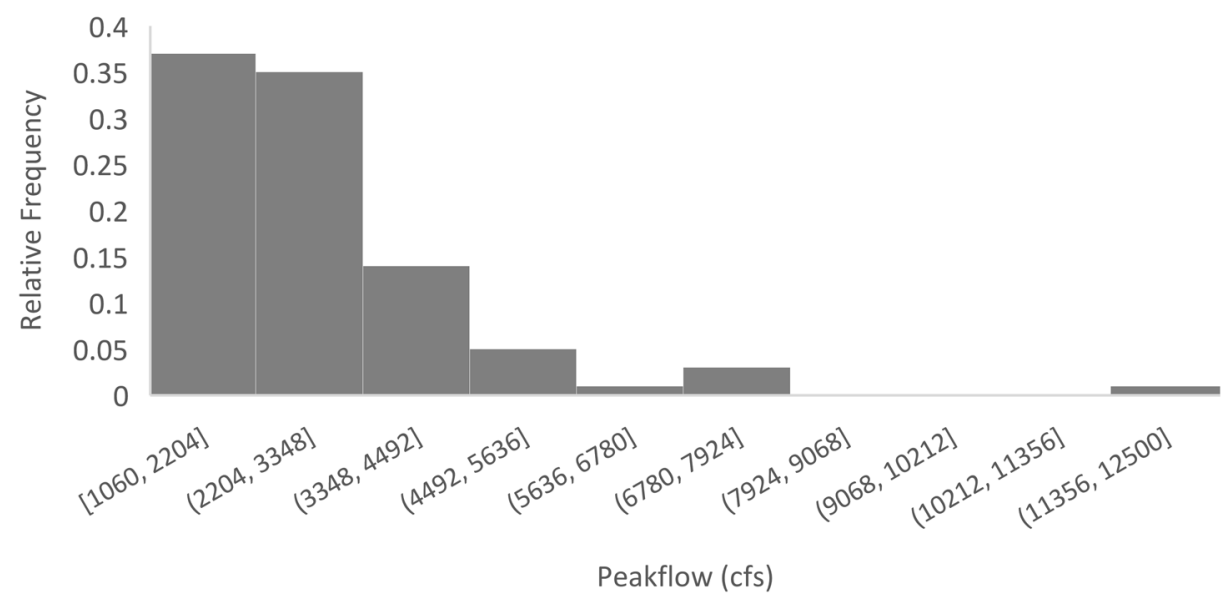

Figure 39: Relative frequency histogram for Blackwater River at Davis gage

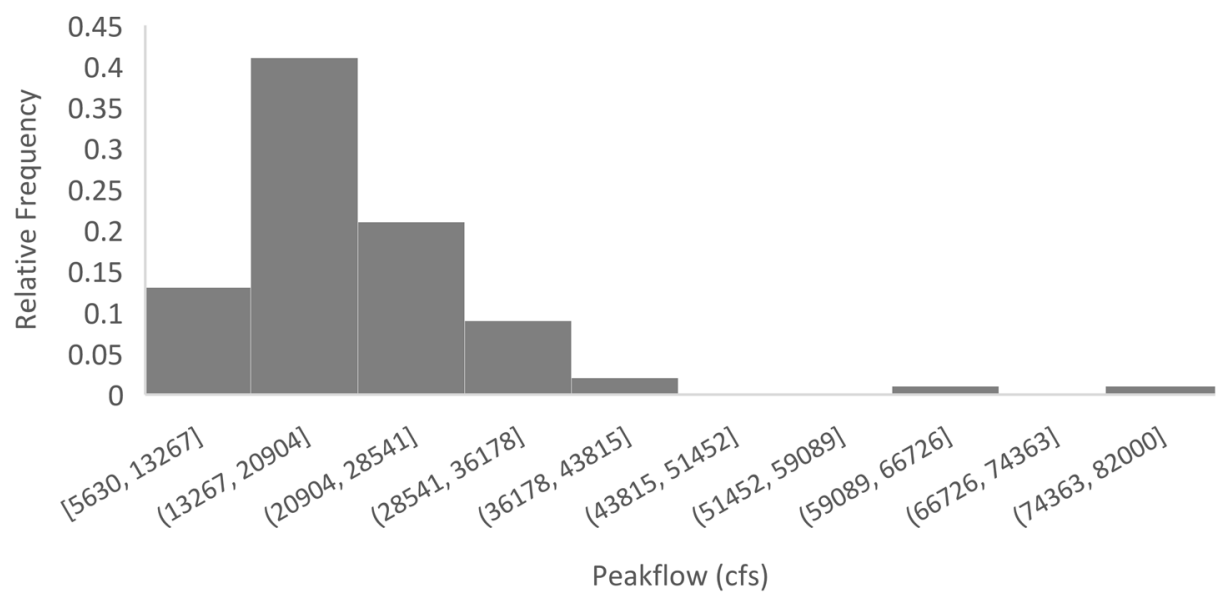

Figure 40: Relative frequency histogram for Greenbrier River at Buckeye gage 


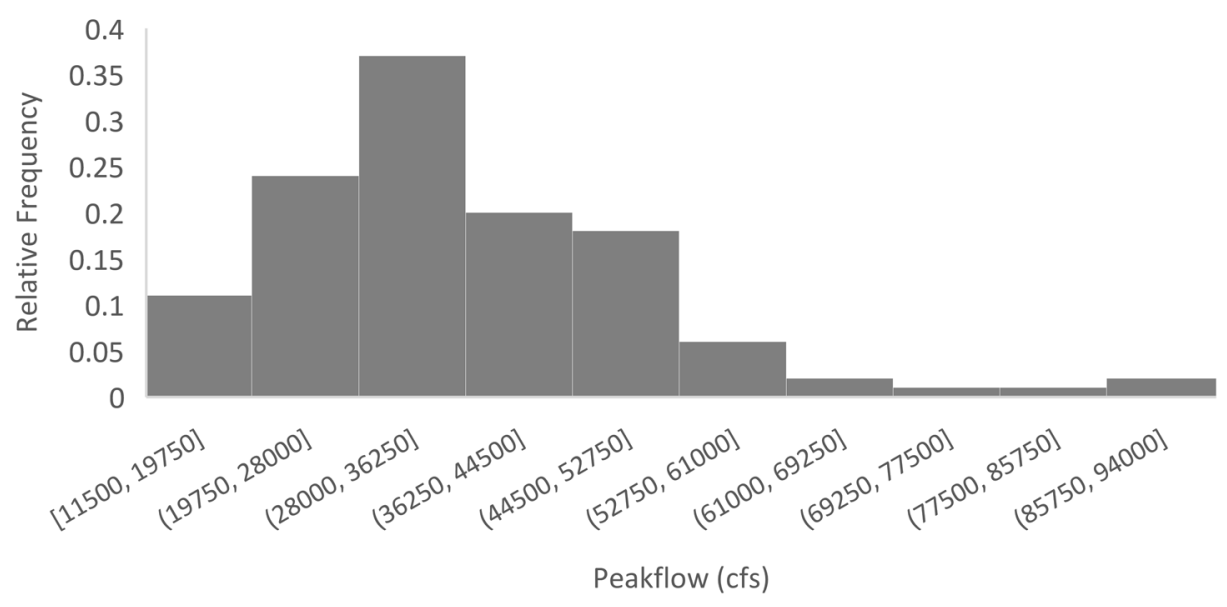

Figure 41: Relative frequency histogram for Greenbrier River at Alderson gage

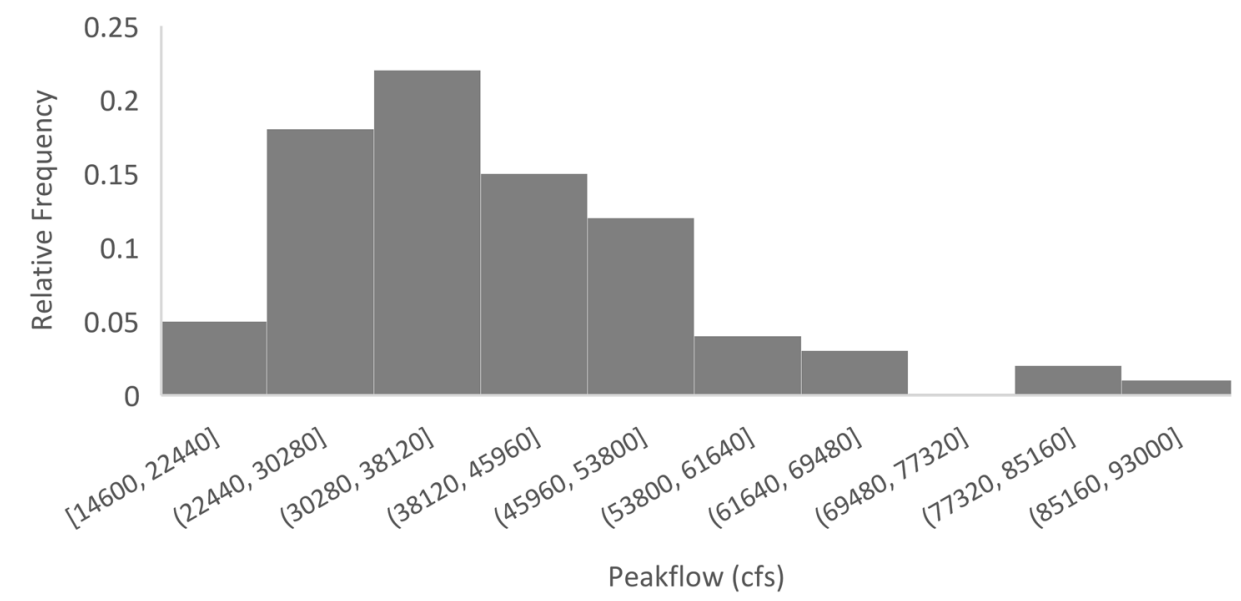

Figure 42: Relative frequency histogram for Greenbrier River at Hilldale gage

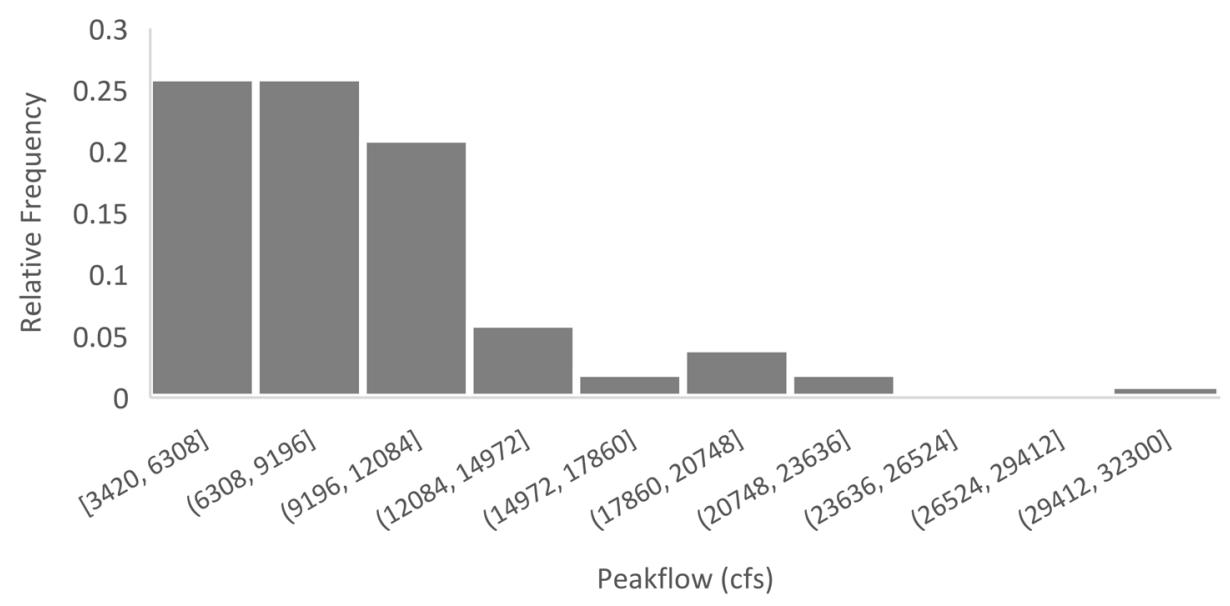

Figure 43: Relative frequency histogram for Williams River at Dyer gage 


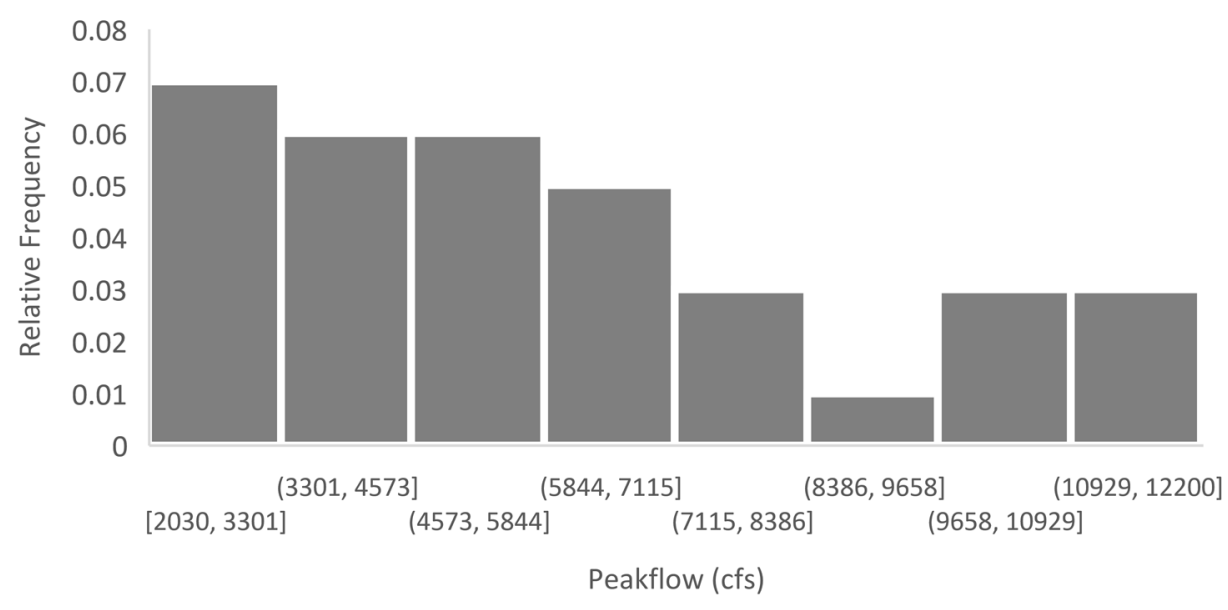

Figure 44: Relative frequency histogram for Cranberry River near Richwood gage

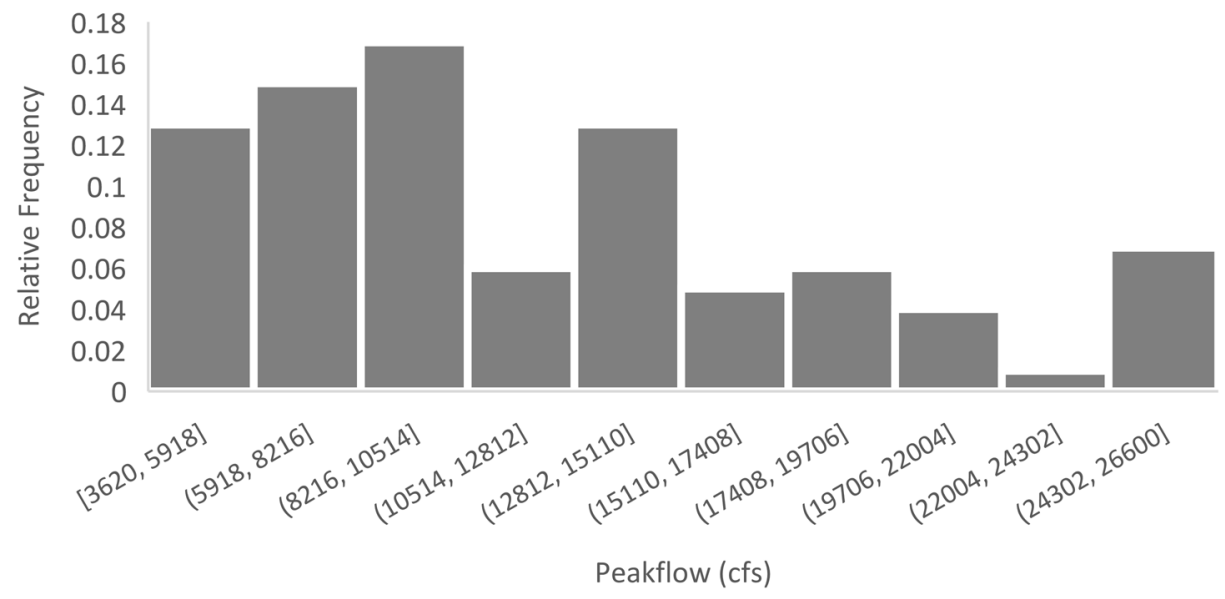

Figure 45: Relative frequency histogram for Big Coal River at Ashford gage

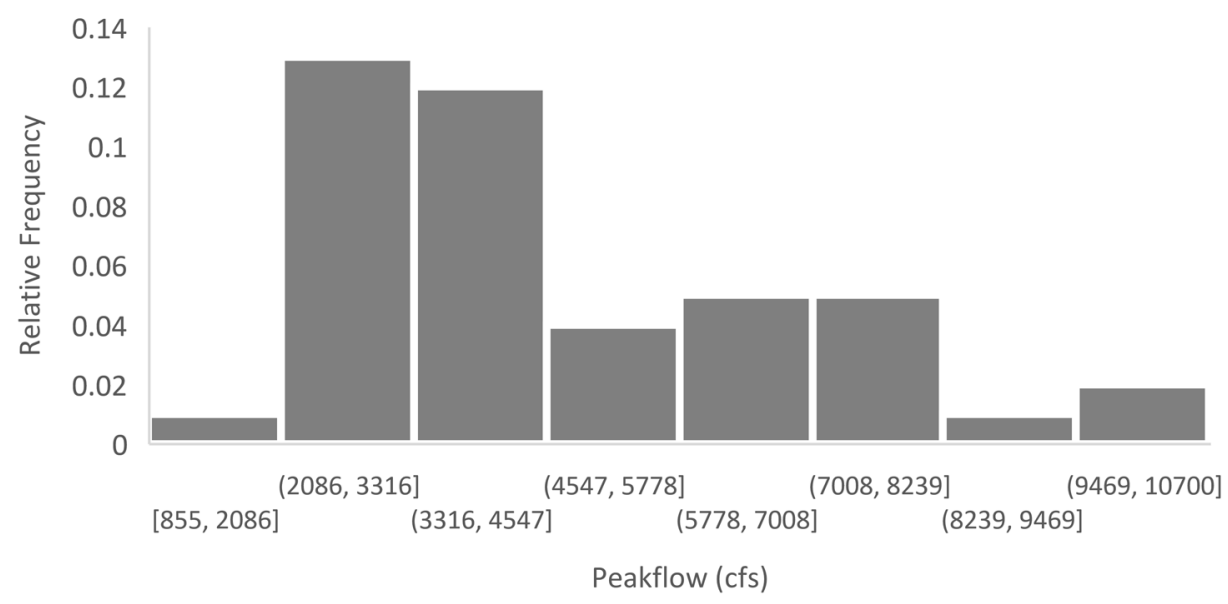

Figure 46: Relative frequency histogram for Clear Fork at Clear Fork gage 


\section{Appendix B: 100-year flow data from HEC-SSP results}

Table 8: All results for all gages from HEC-SSP frequency analyses including gage name, USGS gage number, and total years of record along with 100 -year flow, variance, and confidence limits for each period of record

\begin{tabular}{|l|l|l|l|l|}
\hline $\begin{array}{l}\text { BIG SANDY CREEK AT } \\
\text { ROCKVILLE, WV }\end{array}$ & & & & \\
\hline 3070500 & & & & \\
\hline 96 Years & & & & \\
\hline Frequency Curves (1\%) & & & $\begin{array}{l}\text { Confidence } \\
\text { Limits }\end{array}$ & \\
\hline Years & Flow (CFS) & Variance & 0.05 & 0.95 \\
\hline $1922-2017$ & $20,976.30$ & 0.00487 & $32,469.10$ & $17,252.60$ \\
\hline $1928-2017$ & $21,373.20$ & 0.00522 & $33,830.10$ & $17,473.80$ \\
\hline $1938-2017$ & $21,815.60$ & 0.00573 & $35,607.60$ & $17,687.50$ \\
\hline $1948-2017$ & $22,385.30$ & 0.00659 & $38,445.10$ & $17,908.40$ \\
\hline $1958-2017$ & $19,413.50$ & 0.00578 & $32,440.10$ & $15,761.60$ \\
\hline $1968-2017$ & $19,239.80$ & 0.00705 & $35,477.60$ & $15,360.70$ \\
\hline $1978-2017$ & $17,947.90$ & 0.00744 & $34,419.70$ & $14,268.40$ \\
\hline $1988-2017$ & $19,267.20$ & 0.01108 & $44,394.50$ & $14,664.60$ \\
\hline $1998-2017$ & $17,812.60$ & 0.01108 & $41,367.00$ & $13,601.90$ \\
\hline
\end{tabular}

\begin{tabular}{|l|l|l|l|l|}
\hline $\begin{array}{l}\text { TYGART VALLEY RIVER AT } \\
\text { BELINGTON, WV }\end{array}$ & & & & \\
\hline 3051000 & & & & \\
\hline 110 Years & & & & \\
\hline Frequency Curves (1\%) & & & $\begin{array}{l}\text { Confidence } \\
\text { Limits }\end{array}$ & \\
\hline Years & Flow (CFS) & Variance & 0.05 & 0.95 \\
\hline $1908-2017$ & $22,431.70$ & 0.00152 & $27,490.70$ & $19,910.40$ \\
\hline $1918-2017$ & $22,717.10$ & 0.0018 & $28,445.10$ & $19,995.40$ \\
\hline $1928-2017$ & $22,963.60$ & 0.00203 & $29,455.80$ & $20,087.70$ \\
\hline $1938-2017$ & $23,476.40$ & 0.00243 & $31,107.80$ & $20,319.30$ \\
\hline $1948-2017$ & $24,201.10$ & 0.00314 & $34,130.30$ & $20,645.80$ \\
\hline $1958-2017$ & $25,749.20$ & 0.00501 & $42,543.90$ & $21,277.70$ \\
\hline $1968-2017$ & $26,588.70$ & 0.00615 & $47,330.50$ & $21,569.50$ \\
\hline $1978-2017$ & $28,205.30$ & 0.00931 & $56,640.90$ & $21,779.50$ \\
\hline $1988-2017$ & $23,440.10$ & 0.0057 & $41,509.60$ & $19,143.70$ \\
\hline $1998-2017$ & $18,578.60$ & 0.00344 & $27,560.90$ & $15,860.90$ \\
\hline
\end{tabular}




\begin{tabular}{|l|l|l|l|l|}
\hline $\begin{array}{l}\text { SAND RUN NEAR } \\
\text { BUCKHANNON, WV }\end{array}$ & & & & \\
\hline 3052500 & & & & \\
\hline 71 Years & & & & \\
\hline Frequency Curves (1\%) & & & $\begin{array}{l}\text { Confidence } \\
\text { Limits }\end{array}$ & \\
\hline Years & Flow (CFS) & Variance & 0.05 & 0.95 \\
\hline $1947-2017$ & $3,304.20$ & 0.00805 & $5,663.90$ & $2,554.70$ \\
\hline $1948-2017$ & $3,330.20$ & 0.00853 & $5,767.60$ & $2,555.40$ \\
\hline $1958-2017$ & $3,498.70$ & 0.01173 & $7,207.30$ & $2,596.40$ \\
\hline $1968-2017$ & $3,658.30$ & 0.01222 & $7,701.70$ & $2,697.50$ \\
\hline $1978-2017$ & $4,110.60$ & 0.01576 & $9,755.50$ & $2,915.90$ \\
\hline $1988-2017$ & $3,765.40$ & 0.01393 & $8,234.70$ & $2,714.10$ \\
\hline $1998-2017$ & $3,317.70$ & 0.02154 & $10,707.10$ & $2,257.20$ \\
\hline
\end{tabular}

\begin{tabular}{|c|c|c|c|c|}
\hline $\begin{array}{l}\text { BLACKWATER RIVER } \\
\text { WV }\end{array}$ & & & & \\
\hline \multicolumn{5}{|l|}{3066000} \\
\hline \multicolumn{5}{|l|}{96 Years } \\
\hline Frequency Curves (1\%) & & & $\begin{array}{l}\text { Confidence } \\
\text { Limits }\end{array}$ & \\
\hline Years & Flow (CFS) & Variance & 0.05 & 0.95 \\
\hline $1922-2017$ & $9,081.70$ & 0.00631 & $14,781.50$ & $7,255.50$ \\
\hline $1928-2017$ & $8,868.30$ & 0.0064 & $14,640.70$ & $7,087.80$ \\
\hline $1938-2017$ & $9,258.00$ & 0.00747 & $16,244.00$ & $7,289.00$ \\
\hline $1948-2017$ & $9,598.60$ & 0.00912 & $18,129.70$ & $7,390.50$ \\
\hline $1958-2017$ & $9,575.30$ & 0.01095 & $19,484.10$ & $7,202.00$ \\
\hline $1968-2017$ & $10,267.00$ & 0.01709 & $23,639.60$ & $7,159.50$ \\
\hline $1978-2017$ & $11,566.60$ & 0.02438 & $32,178.60$ & $7,553.70$ \\
\hline $1988-2017$ & $8,545.90$ & 0.01543 & $22,732.40$ & $6,178.10$ \\
\hline $1998-2017$ & $5,484.10$ & 0.00597 & $9,070.80$ & $4,422.50$ \\
\hline
\end{tabular}




\begin{tabular}{|l|l|l|l|l|}
\hline $\begin{array}{l}\text { LITTLE KANAWHA RIVER NR } \\
\text { WILDCAT, WV }\end{array}$ & & & & \\
\hline 3151400 & & & & \\
\hline 32 Years & & & & \\
\hline Frequency Curves (1\%) & & & $\begin{array}{l}\text { Confidence } \\
\text { Limits }\end{array}$ & \\
\hline Years & Flow (CFS) & Variance & 0.05 & 0.95 \\
\hline $1986-2017$ & $25,483.30$ & 0.03455 & $95,925.30$ & $15,542.10$ \\
\hline $1988-2017$ & $25,561.00$ & 0.03874 & $102,276.40$ & $15,131.40$ \\
\hline $1998-2017$ & $20,213.70$ & 0.0428 & $81,073.90$ & $11,604.60$ \\
\hline
\end{tabular}

\begin{tabular}{|l|l|l|l|l|}
\hline $\begin{array}{l}\text { BLUESTONE RIVER NEAR } \\
\text { PIPESTEM, WV }\end{array}$ & & & & \\
\hline 3179000 & & & & \\
\hline 67 Years & & & & \\
\hline Frequency Curves (1\%) & & & $\begin{array}{l}\text { Confidence } \\
\text { Limits }\end{array}$ & \\
\hline Years & Flow (CFS) & Variance & 0.05 & 0.95 \\
\hline $1951-2017$ & $23,055.30$ & 0.00327 & $31,170.40$ & $19,387.70$ \\
\hline $1958-2017$ & $22,379.40$ & 0.00319 & $30,226.60$ & $18,875.30$ \\
\hline $1968-2017$ & $22,738.70$ & 0.0036 & $31,494.20$ & $18,962.90$ \\
\hline $1978-2017$ & $23,676.60$ & 0.00506 & $35,678.50$ & $19,222.10$ \\
\hline $1988-2017$ & $26,458.90$ & 0.00878 & $50,835.80$ & $20,417.10$ \\
\hline $1998-2017$ & $28,780.00$ & 0.01336 & $56,737.10$ & $20,601.30$ \\
\hline
\end{tabular}

\begin{tabular}{|l|l|l|l|l|}
\hline $\begin{array}{l}\text { GREENBRIER RIVER AT } \\
\text { BUCKEYE, WV }\end{array}$ & & & & \\
\hline 3182500 & & & & \\
\hline 88 Years & & & & \\
\hline Frequency Curves (1\%) & & & $\begin{array}{l}\text { Confidence } \\
\text { Limits }\end{array}$ & \\
\hline Years & Flow (CFS) & Variance & 0.05 & 0.95 \\
\hline $1930-2017$ & $57,956.90$ & 0.00438 & $84,764.00$ & $47,819.80$ \\
\hline $1938-2017$ & $60,129.60$ & 0.00624 & $99,975.50$ & $48,289.80$ \\
\hline $1948-2017$ & $63,397.00$ & 0.0079 & $115,400.60$ & $49,744.00$ \\
\hline $1958-2017$ & $67,298.90$ & 0.01011 & $133,891.60$ & $51,223.60$ \\
\hline $1968-2017$ & $70,103.00$ & 0.01144 & $152,970.50$ & $52,682.70$ \\
\hline $1978-2017$ & $74,611.90$ & 0.01466 & $187,433.10$ & $54,183.60$ \\
\hline $1988-2017$ & $54,462.30$ & 0.00691 & $95,673.50$ & $43,307.60$ \\
\hline $1998-2017$ & $41,361.00$ & 0.00443 & $64,733.50$ & $34,320.60$ \\
\hline
\end{tabular}




\begin{tabular}{|l|l|l|l|l|}
\hline $\begin{array}{l}\text { GREENBRIER RIVER AT } \\
\text { ALDERSON, WV }\end{array}$ & & & & \\
\hline 3183500 & & & & \\
\hline 122 Years & & & & \\
\hline Frequency Curves (1\%) & & & $\begin{array}{l}\text { Confidence } \\
\text { Limits }\end{array}$ & \\
\hline Years & Flow (CFS) & Variance & 0.05 & 0.95 \\
\hline $1896-2017$ & $79,865.50$ & 0.0013 & $94,778.60$ & $71,187.50$ \\
\hline $1898-2017$ & $79,856.90$ & 0.00133 & $94,935.10$ & $71,077.30$ \\
\hline $1908-2017$ & $80,123.80$ & 0.00155 & $96,773.80$ & $70,746.70$ \\
\hline $1918-2017$ & $80,344.10$ & 0.00198 & $99,108.60$ & $70,402.50$ \\
\hline $1928-2017$ & $81,613.30$ & 0.00242 & $107,500.90$ & $70,653.20$ \\
\hline $1938-2017$ & $87,183.50$ & 0.00408 & $130,674.10$ & $72,949.50$ \\
\hline $1948-2017$ & $91,290.00$ & 0.00505 & $147,654.70$ & $75,172.60$ \\
\hline $1958-2017$ & $96,209.20$ & 0.00653 & $169,110.10$ & $77,343.70$ \\
\hline $1968-2017$ & $99,789.60$ & 0.00801 & $190,518.80$ & $78,537.10$ \\
\hline $1978-2017$ & $103,144.90$ & 0.0115 & $224,193.50$ & $77,391.60$ \\
\hline $1988-2017$ & $97,900.00$ & 0.01222 & $233,763.80$ & $73,272.10$ \\
\hline $1998-2017$ & $85,774.30$ & 0.0112 & $200,047.60$ & $65,335.50$ \\
\hline
\end{tabular}

\begin{tabular}{|l|l|l|l|l|}
\hline $\begin{array}{l}\text { GREENBRIER RIVER AT } \\
\text { HILLDALE, WV }\end{array}$ & & & & \\
\hline 3184000 & & & & \\
\hline 82 Years & & & & \\
\hline Frequency Curves (1\%) & & & $\begin{array}{l}\text { Confidence } \\
\text { Limits }\end{array}$ & \\
\hline Years & Flow (CFS) & Variance & 0.05 & 0.95 \\
\hline $1936-2017$ & $86,556.00$ & 0.00219 & $111,483.40$ & $75,260.10$ \\
\hline $1938-2017$ & $86,543.40$ & 0.00232 & $112,725.60$ & $74,961.70$ \\
\hline $1948-2017$ & $91,893.70$ & 0.00337 & $130,662.60$ & $77,892.20$ \\
\hline $1958-2017$ & $95,957.70$ & 0.00445 & $148,572.40$ & $79,759.30$ \\
\hline $1968-2017$ & $98,456.50$ & 0.0054 & $162,165.80$ & $80,503.00$ \\
\hline $1978-2017$ & $99,338.30$ & 0.00725 & $188,587.80$ & $79,193.40$ \\
\hline $1988-2017$ & $97,054.20$ & 0.00825 & $199,566.40$ & $76,574.50$ \\
\hline $1998-2017$ & $88,265.10$ & 0.00841 & $182,826.30$ & $69,357.60$ \\
\hline
\end{tabular}




\begin{tabular}{|c|c|c|c|c|}
\hline \multicolumn{5}{|c|}{ NEW RIVER AT THURMOND, WV } \\
\hline \multicolumn{5}{|l|}{3185400} \\
\hline \multicolumn{5}{|l|}{37 Years } \\
\hline Frequency Curves (1\%) & & & $\begin{array}{l}\text { Confidence } \\
\text { Limits }\end{array}$ & \\
\hline Years & Flow (CFS) & Variance & 0.05 & 0.95 \\
\hline $1981-2017$ & $108,702.70$ & 0.00108 & $128,806.10$ & $98,299.90$ \\
\hline $1988-2017$ & $110,318.40$ & 0.00133 & $133,927.40$ & $98,750.60$ \\
\hline $1998-2017$ & $115,253.50$ & 0.00238 & $153,297.50$ & $100,061.60$ \\
\hline
\end{tabular}

\begin{tabular}{|c|c|c|c|c|}
\hline WILLIAMS RIVER AT D & & & & \\
\hline \multicolumn{5}{|l|}{3186500} \\
\hline \multicolumn{5}{|l|}{88 Years } \\
\hline Frequency Curves (1\%) & & & $\begin{array}{l}\text { Confidence } \\
\text { Limits }\end{array}$ & \\
\hline Years & Flow (CFS) & Variance & 0.05 & 0.95 \\
\hline $1930-2017$ & $28,013.10$ & 0.00573 & $44,130.20$ & $22,570.40$ \\
\hline $1938-2017$ & $27,489.70$ & 0.00578 & $43,507.20$ & $22,136.70$ \\
\hline $1948-2017$ & $28,990.00$ & 0.0071 & $49,451.50$ & $22,898.20$ \\
\hline $1958-2017$ & $30,898.60$ & 0.00885 & $57,294.00$ & $23,811.70$ \\
\hline $1968-2017$ & $32,429.80$ & 0.00988 & $63,475.10$ & $24,665.50$ \\
\hline $1978-2017$ & $34,746.20$ & 0.01149 & $72,716.90$ & $25,916.60$ \\
\hline $1988-2017$ & $32,978.50$ & 0.01352 & $79,161.50$ & $24,180.50$ \\
\hline $1998-2017$ & $36,352.70$ & 0.02671 & $131,478.70$ & $23,919.60$ \\
\hline
\end{tabular}

\begin{tabular}{|l|l|l|l|l|}
\hline $\begin{array}{l}\text { CRANBERRY RIVER NEAR } \\
\text { RICHWOOD, WV }\end{array}$ & & & & \\
\hline 3187500 & & & & \\
\hline 34 Years & & & & \\
\hline Frequency Curves (1\%) & & & $\begin{array}{l}\text { Confidence } \\
\text { Limits }\end{array}$ & \\
\hline Years & Flow (CFS) & Variance & 0.05 & 0.95 \\
\hline $1984-2017$ & $16,787.90$ & 0.00833 & $28,854.70$ & $13,026.50$ \\
\hline $1988-2017$ & $15,628.40$ & 0.00868 & $26,758.30$ & $12,155.30$ \\
\hline $1998-2017$ & $15,420.90$ & 0.01073 & $32,921.10$ & $11,658.80$ \\
\hline
\end{tabular}




\begin{tabular}{|l|l|l|l|l|}
\hline $\begin{array}{l}\text { GAULEY RIVER NEAR } \\
\text { CRAIGSVILLE, WV }\end{array}$ & & & & \\
\hline 3189100 & & & & \\
\hline 32 Years & & & & \\
\hline Frequency Curves (1\%) & & & $\begin{array}{l}\text { Confidence } \\
\text { Limits }\end{array}$ & \\
\hline Years & Flow (CFS) & Variance & 0.05 & 0.95 \\
\hline $1986-2017$ & $94,684.90$ & 0.01235 & $205,434.20$ & $69,847.40$ \\
\hline $1988-2017$ & $88,902.50$ & 0.0118 & $190,712.20$ & $66,086.40$ \\
\hline $1998-2017$ & $98,159.50$ & 0.02069 & $310,203.50$ & $67,598.60$ \\
\hline
\end{tabular}

\begin{tabular}{|l|l|l|l|l|}
\hline $\begin{array}{l}\text { GAULEY RIVER ABOVE BELVA, } \\
\text { WV }\end{array}$ & & & & \\
\hline 3192000 & & & & \\
\hline 89 Years & & & & \\
\hline Frequency Curves (1\%) & & & $\begin{array}{l}\text { Confidence } \\
\text { Limits }\end{array}$ & \\
\hline Years & Flow (CFS) & Variance & 0.05 & 0.95 \\
\hline $1929-2017$ & $98,932.40$ & 0.00595 & $162,909.30$ & $79,898.80$ \\
\hline $1938-2017$ & $90,829.40$ & 0.00585 & $150,660.70$ & $73,595.30$ \\
\hline $1948-2017$ & $77,907.60$ & 0.00536 & $128,697.30$ & $63,837.60$ \\
\hline $1958-2017$ & $65,089.70$ & 0.00536 & $106,448.10$ & $53,283.40$ \\
\hline $1968-2017$ & $68,173.20$ & 0.00969 & $122,044.20$ & $51,559.50$ \\
\hline $1978-2017$ & $73,401.10$ & 0.01188 & $137,371.80$ & $53,706.10$ \\
\hline $1988-2017$ & $80,192.60$ & 0.01636 & $174,119.60$ & $56,110.60$ \\
\hline $1998-2017$ & $96,643.50$ & 0.02776 & $289,682.00$ & $61,752.00$ \\
\hline
\end{tabular}




\begin{tabular}{|l|l|l|l|l|}
\hline $\begin{array}{l}\text { KANAWHA RIVER AT } \\
\text { KANAWHA FALLS, WV }\end{array}$ & & & & \\
\hline 3193000 & & & & \\
\hline 140 Years & & & & \\
\hline Frequency Curves (1\%) & & & $\begin{array}{l}\text { Confidence } \\
\text { Limits }\end{array}$ & \\
\hline Years & Flow (CFS) & Variance & 0.05 & 0.95 \\
\hline $1878-2017$ & $277,734.90$ & 0.00215 & $355,599.00$ & $241,691.40$ \\
\hline $1888-2017$ & $259,760.40$ & 0.00186 & $325,768.20$ & $228,004.00$ \\
\hline $1898-2017$ & $258,678.60$ & 0.00221 & $334,074.60$ & $224,930.30$ \\
\hline $1908-2017$ & $224,703.80$ & 0.00185 & $284,990.80$ & $197,921.30$ \\
\hline $1918-2017$ & $203,201.10$ & 0.00153 & $251,950.20$ & $180,939.00$ \\
\hline $1928-2017$ & $198,602.70$ & 0.00162 & $248,536.70$ & $176,426.00$ \\
\hline $1938-2017$ & $193,150.70$ & 0.00196 & $252,641.80$ & $170,273.40$ \\
\hline $1948-2017$ & $158,779.60$ & 0.00089 & $185,566.60$ & $145,379.40$ \\
\hline $1958-2017$ & $153,540.40$ & 0.00098 & $179,262.40$ & $140,603.00$ \\
\hline $1968-2017$ & $154,137.70$ & 0.0011 & $185,248.50$ & $140,124.50$ \\
\hline $1978-2017$ & $154,777.90$ & 0.00134 & $192,991.40$ & $139,408.30$ \\
\hline $1988-2017$ & $159,244.60$ & 0.00185 & $209,443.40$ & $141,150.70$ \\
\hline $1998-2017$ & $171,467.90$ & 0.00396 & $282,892.30$ & $145,171.50$ \\
\hline
\end{tabular}

\begin{tabular}{|l|l|l|l|l|}
\hline $\begin{array}{l}\text { ELK RIVER BELOW WEBSTER } \\
\text { SPRINGS, WV }\end{array}$ & & & & \\
\hline 3194700 & & & & \\
\hline 32 Years & & & & \\
\hline Frequency Curves (1\%) & & & $\begin{array}{l}\text { Confidence } \\
\text { Limits }\end{array}$ & \\
\hline Years & Flow (CFS) & Variance & 0.05 & 0.95 \\
\hline $1986-2017$ & $44,838.70$ & 0.00817 & $75,596.10$ & $34,498.30$ \\
\hline $1988-2017$ & $38,866.90$ & 0.0065 & $59,305.20$ & $30,394.20$ \\
\hline $1998-2017$ & $33,658.50$ & 0.00637 & $52,727.70$ & $26,554.20$ \\
\hline
\end{tabular}




\begin{tabular}{|c|c|c|c|c|}
\hline \multicolumn{5}{|c|}{$\begin{array}{l}\text { ELK RIVER AT QUEEN SHOALS, } \\
\text { WV }\end{array}$} \\
\hline \multicolumn{5}{|l|}{3197000} \\
\hline \multicolumn{5}{|l|}{89 Years } \\
\hline Frequency Curves (1\%) & & & $\begin{array}{l}\text { Confidence } \\
\text { Limits }\end{array}$ & \\
\hline Years & Flow (CFS) & Variance & 0.05 & 0.95 \\
\hline $1929-2017$ & $67,548.20$ & 0.00345 & $92,893.10$ & $56,739.00$ \\
\hline $1938-2017$ & $63,766.90$ & 0.00364 & $88,826.90$ & $53,261.40$ \\
\hline $1948-2017$ & $61,277.10$ & 0.00391 & $86,990.00$ & $50,961.80$ \\
\hline $1958-2017$ & $63,093.40$ & 0.00592 & $101,335.80$ & $50,689.00$ \\
\hline $1968-2017$ & $65,652.00$ & 0.00772 & $115,457.40$ & $51,305.80$ \\
\hline $1978-2017$ & $72,837.20$ & 0.01315 & $170,058.90$ & $53,597.20$ \\
\hline $1988-2017$ & $78,580.90$ & 0.01805 & $228,457.70$ & $55,387.80$ \\
\hline $1998-2017$ & $92,748.70$ & 0.04046 & $431,372.60$ & $55,002.30$ \\
\hline
\end{tabular}

\begin{tabular}{|l|l|l|l|l|}
\hline $\begin{array}{l}\text { BIG COAL RIVER AT ASHFORD, } \\
\text { WV }\end{array}$ & & & & \\
\hline 3198500 & & & & \\
\hline 87 Years & & & & \\
\hline Frequency Curves (1\%) & & & $\begin{array}{l}\text { Confidence } \\
\text { Limits }\end{array}$ & \\
\hline Years & Flow (CFS) & Variance & 0.05 & 0.95 \\
\hline $1931-2017$ & $30,038.30$ & 0.00367 & $51,245.90$ & $25,965.40$ \\
\hline $1938-2017$ & $36,751.40$ & 0.00478 & $52,428.50$ & $29,876.20$ \\
\hline $1948-2017$ & $36,618.10$ & 0.00534 & $53,910.10$ & $29,464.50$ \\
\hline $1958-2017$ & $38,748.20$ & 0.00673 & $61,403.40$ & $30,443.70$ \\
\hline $1968-2017$ & $36,614.50$ & 0.00693 & $59,138.60$ & $28,736.10$ \\
\hline $1978-2017$ & $34,496.30$ & 0.00795 & $58,912.50$ & $26,716.90$ \\
\hline $1988-2017$ & $34,606.40$ & 0.01101 & $67,780.90$ & $25,790.00$ \\
\hline $1998-2017$ & $39,363.00$ & 0.02223 & $128,802.80$ & $26,536.80$ \\
\hline
\end{tabular}




\begin{tabular}{|l|l|l|l|l|}
\hline $\begin{array}{l}\text { GUYANDOTTE RIVER NEAR } \\
\text { BAILEYSVILLE, WV }\end{array}$ & & & & \\
\hline 3202400 & & & & \\
\hline 49 Years & & & & \\
\hline Frequency Curves (1\%) & & & $\begin{array}{l}\text { Confidence } \\
\text { Limits }\end{array}$ & \\
\hline Years & Flow (CFS) & Variance & 0.05 & 0.95 \\
\hline $1969-2017$ & $54,058.90$ & 0.01721 & $118,256.60$ & $37,088.20$ \\
\hline $1978-2017$ & $54,324.40$ & 0.02455 & $156,497.20$ & $35,326.30$ \\
\hline $1988-2017$ & $64,010.80$ & 0.03797 & $284,336.10$ & $38,110.10$ \\
\hline $1998-2017$ & $80,977.70$ & 0.05842 & $557,203.10$ & $42,941.90$ \\
\hline
\end{tabular}

\begin{tabular}{|c|c|c|c|c|}
\hline \multicolumn{5}{|c|}{$\begin{array}{l}\text { CLEAR FORK AT CLEAR FORK, } \\
\text { WV }\end{array}$} \\
\hline \multicolumn{5}{|l|}{3202750} \\
\hline \multicolumn{5}{|l|}{43 Years } \\
\hline Frequency Curves (1\%) & & & $\begin{array}{l}\text { Confidence } \\
\text { Limits }\end{array}$ & \\
\hline Years & Flow (CFS) & Variance & 0.05 & 0.95 \\
\hline $1975-2017$ & $12,938.00$ & 0.00808 & $24,846.10$ & $10,146.50$ \\
\hline $1978-2017$ & $12,251.90$ & 0.0076 & $23,086.40$ & $9,676.30$ \\
\hline $1988-2017$ & $12,912.90$ & 0.01257 & $31,612.80$ & $9,667.90$ \\
\hline $1998-2017$ & $14,761.60$ & 0.02112 & $47,234.30$ & $10,161.80$ \\
\hline
\end{tabular}

\begin{tabular}{|l|l|l|l|l|}
\hline $\begin{array}{l}\text { GUYANDOTTE RIVER AT } \\
\text { LOGAN, WV }\end{array}$ & & & & \\
\hline 3203600 & & & & \\
\hline 57 Years & & & & \\
\hline Frequency Curves (1\%) & & & $\begin{array}{l}\text { Confidence } \\
\text { Limits }\end{array}$ & \\
\hline Years & Flow (CFS) & Variance & 0.05 & 0.95 \\
\hline $1961-2017$ & $62,491.20$ & 0.00765 & $101,912.50$ & $48,295.80$ \\
\hline $1968-2017$ & $55,356.60$ & 0.00805 & $91,122.40$ & $42,758.60$ \\
\hline $1978-2017$ & $39,589.90$ & 0.00581 & $59,723.20$ & $31,531.60$ \\
\hline $1988-2017$ & $34,925.00$ & 0.00807 & $61,945.40$ & $27,688.10$ \\
\hline $1998-2017$ & $37,251.70$ & 0.01257 & $86,763.40$ & $27,580.00$ \\
\hline
\end{tabular}




\begin{tabular}{|c|c|c|c|c|}
\hline $\begin{array}{l}\text { EAST FORK TWELVEPOLE } \\
\text { CREEK NEAR DUNLOW, WV }\end{array}$ & & & & \\
\hline 3206600 & & & & \\
\hline 53 Years & & & & \\
\hline Frequency Curves (1\%) & & & $\begin{array}{l}\text { Confidence } \\
\text { Limits }\end{array}$ & \\
\hline Years & Flow (CFS) & Variance & 0.05 & 0.95 \\
\hline $1965-2017$ & $4,459.50$ & 0.0034 & $5,908.40$ & $3,708.70$ \\
\hline $1968-2017$ & $4,428.90$ & 0.00343 & $5,867.50$ & $3,677.90$ \\
\hline $1978-2017$ & $4,624.10$ & 0.00468 & $6,487.00$ & $3,734.80$ \\
\hline $1988-2017$ & $4,090.80$ & 0.00334 & $5,745.20$ & $3,446.90$ \\
\hline $1998-2017$ & $4,520.60$ & 0.00916 & $7,747.60$ & $3,402.10$ \\
\hline
\end{tabular}

\begin{tabular}{|l|l|l|l|l|}
\hline $\begin{array}{l}\text { TUG FORK DOWNSTREAM OF } \\
\text { ELKHORN CREEK AT WELCH, } \\
\text { WV }\end{array}$ & & & & \\
\hline 3212750 & & & & \\
\hline 32 Years & & & & \\
\hline Frequency Curves (1\%) & & & $\begin{array}{l}\text { Confidence } \\
\text { Limits }\end{array}$ & \\
\hline Years & Flow (CFS) & Variance & 0.05 & 0.95 \\
\hline $1986-2017$ & $16,510.30$ & 0.0187 & $36,041.80$ & $11,393.20$ \\
\hline $1988-2017$ & $16,649.70$ & 0.01958 & $37,566.60$ & $11,402.10$ \\
\hline $1998-2017$ & $21,112.90$ & 0.03105 & $75,375.70$ & $13,098.30$ \\
\hline
\end{tabular}

\begin{tabular}{|l|l|l|l|l|}
\hline TUG FORK AT KERMIT, WV & & & & \\
\hline 3214500 & & & & \\
\hline 88 Years & & & & \\
\hline Frequency Curves (1\%) & & & $\begin{array}{l}\text { Confidence } \\
\text { Limits }\end{array}$ & \\
\hline Years & Flow (CFS) & Variance & 0.05 & 0.95 \\
\hline $1930-2017$ & $94,328.50$ & 0.00563 & $138,303.40$ & $75,143.40$ \\
\hline $1938-2017$ & $98,743.10$ & 0.00653 & $150,347.50$ & $77,401.10$ \\
\hline $1948-2017$ & $103,316.40$ & 0.00765 & $163,615.20$ & $79,716.80$ \\
\hline $1958-2017$ & $108,736.80$ & 0.01026 & $193,213.40$ & $80,831.80$ \\
\hline $1968-2017$ & $101,676.20$ & 0.01178 & $192,952.50$ & $74,350.30$ \\
\hline $1978-2017$ & $85,522.20$ & 0.01657 & $227,575.10$ & $60,780.60$ \\
\hline $1988-2017$ & $56,408.60$ & 0.00975 & $108,091.90$ & $43,373.40$ \\
\hline $1998-2017$ & $73,420.70$ & 0.02521 & $261,478.50$ & $48,624.60$ \\
\hline
\end{tabular}

